\title{
موارد مغلطاي ومنهجه في كتابه "مختصر تاريخ الخلقاء"
}

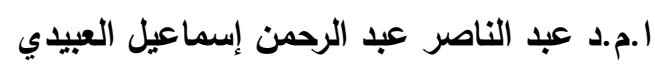

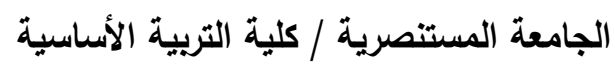

المقدمة

الحمد لله الذي أمرنا أن نأتي البيوت من أبوابها، وأن نسير في طريق مصالحنا بتعرف مناهجها

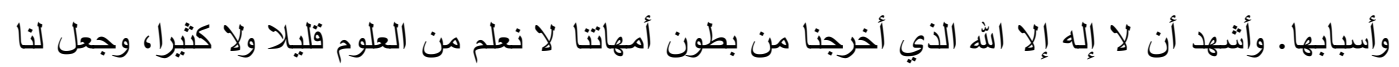

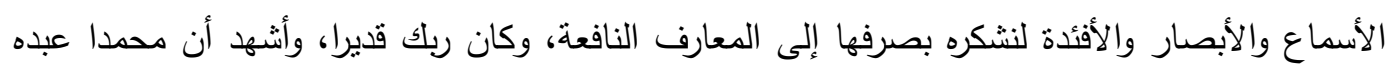

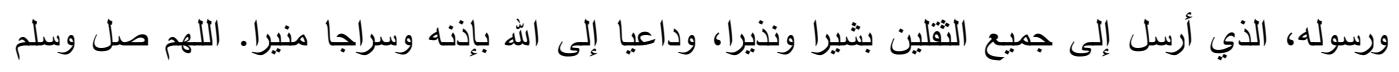
على محمد وعلى آله وأصحابه، صلاة وسلاما كاملا كثيرا.

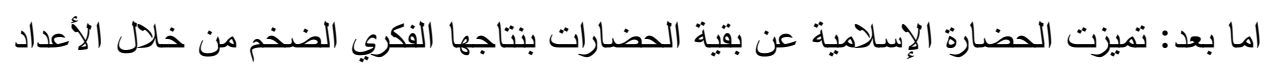

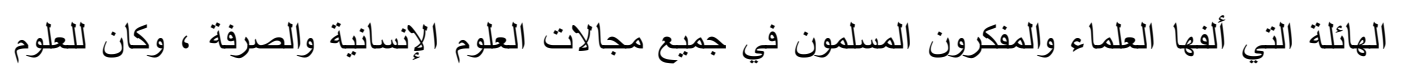

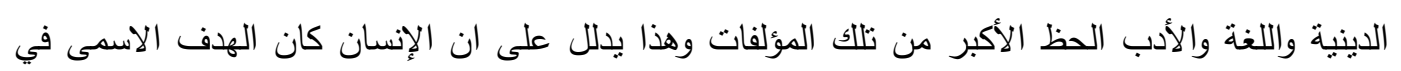
الحضارة الإسلامية وبذللك عدت نقطة تحول في مسيرة البشرية نحو التقدم والرقي.

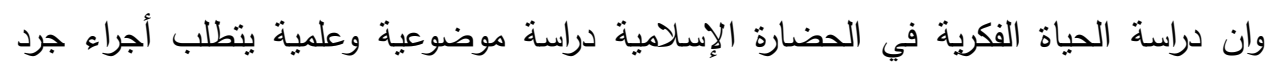

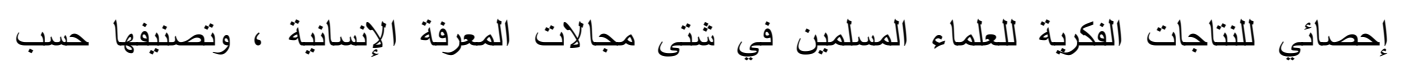

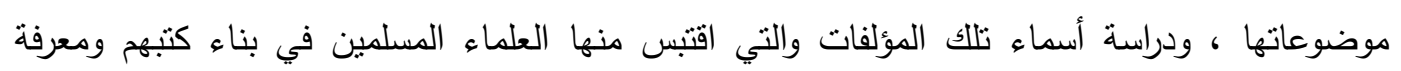

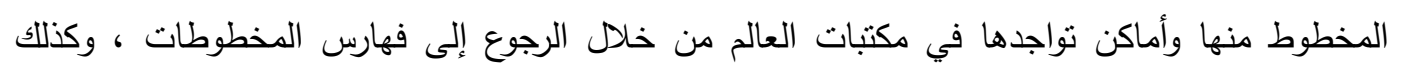

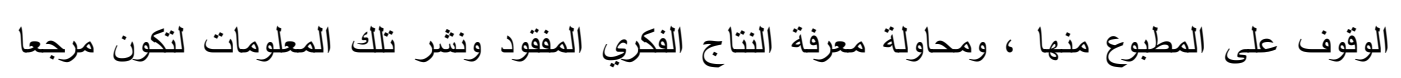

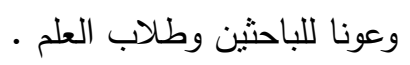

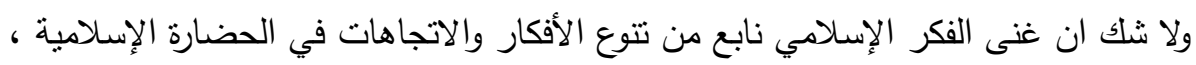

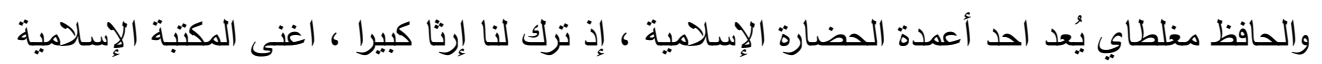
بمؤلفاته المعرفية المتعددة ، فكان كتابه " مختصر تاريخ الخلفاء " محط أنظارنا . 
واعتزازا بعطاء الحافظ مغلطاي العلمية واستذكارا للعصر الذي عاش فيه المليء بالنشاط الفكري ،

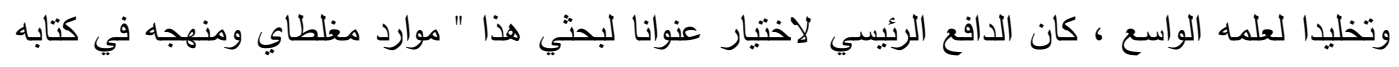

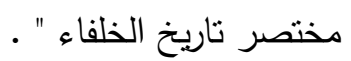
واقتضت ضرورة البحث ان بنتظم بمقدمة وقسمين : القسم الأول : تتاولنا فيه عصر وسيرة الحافظ مغلطاي

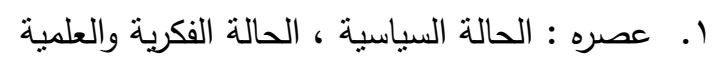
r. سيرة الحافظ مغلطاي :اسمه ونسبه ، نسبته ، كنيته ولقبه ، مذهبه ، مولده ونشأته ، مكانته

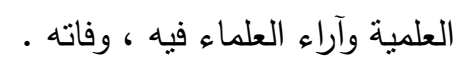

r. مكونات ثقافة الحافظ مغلطاي : رحلاته ، شيوخه ، تلاميذه ، الوظائف والأعمال التي قام بها ، مؤلفاته .

القسم الثاني : تتاولنا فيه دراسة كتاب " مختصر تاريخ الخلفاء" لمغلطاي :

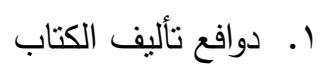

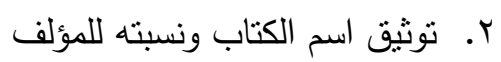

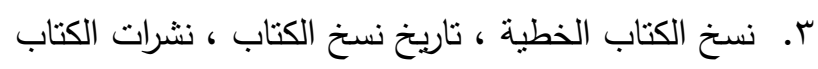
ع. أهمية الكتاب وقيمته العلمبة 0. وصف عام للكتاب ومحتواه

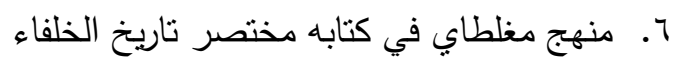
V V موارد مغلطاي في كتابه مختصر تاريخ الخلفاء

هذا وإنني لا ادعي الكمال فيما قمت به ، بل هو جهد المقل ، فان حالفنا الصواب ، فذللك فضل وتوفيق

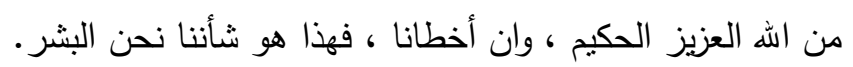
وآخر دعوانا ان الحمد لله رب العالمين الهين 
القسم الأول : عصر وسبرة مغلطاي

أولاًا :عصره :

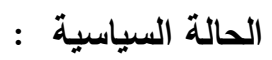

ولد الحافظ مغلطاي في ظل دولة المماليك(') البحرية والتي سكنت قلعة الروضة في عهد الملك الكي

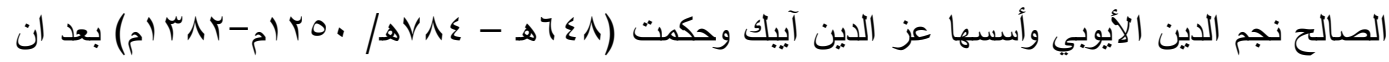

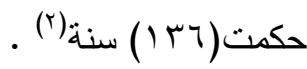

وكان اصل المماليك من الرقيق الأبيض جلبهر بعض حكام المسلمين من أماكن مختلفة وقاموا

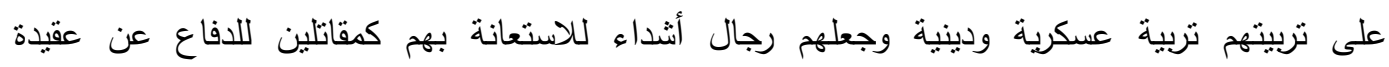

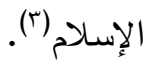

والمتتبع للحالة السياسية السائدة آنذاك يلاحظ انها نأثرت نأثراً واضحاً بالغزو المغولي واحتلال

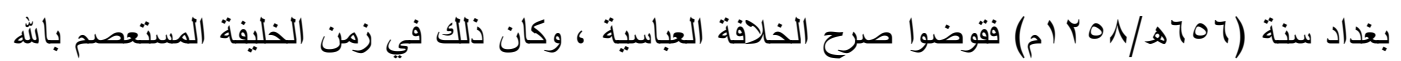
آخر الخلفاء العباسيين في العراق(أ).

ومن أهم الإنجازات التي قامت بها دولة المماليك البحرية هو تصديها للخطر الصليبي

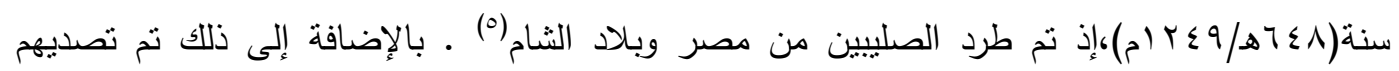

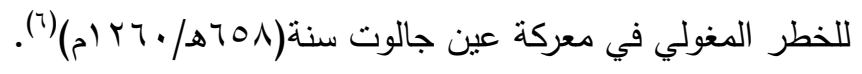

والذي في مبحثا هذا هو حكم سلاطين المماليك البحرية في مصر ، وقد عاصر الحافظ مغلطاي جزءا من حكم هذه الدولة ،وقد برز في دولة المماليك البحرية عدد من السلاطين اسنطاعوا ان يشاركوا في إعمار

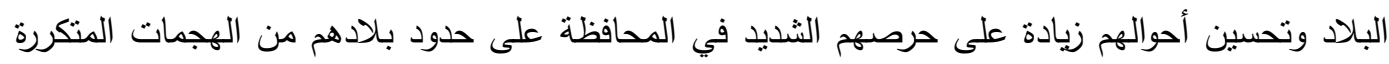

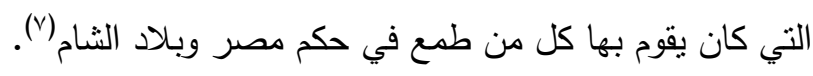

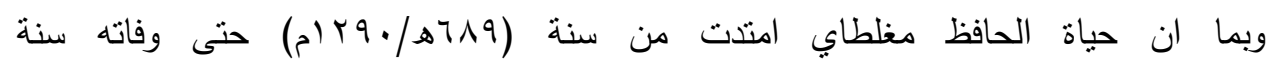
: (r) 


\section{العــــــدد الثاني والعشرون}

\section{مجلـــة كليــــة التربيـــة}

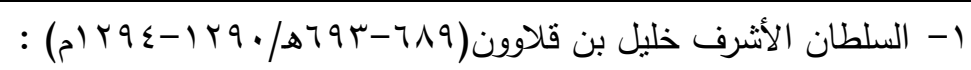

ولي السلطة بعد وفاة أبيه سنة(197هـ)، وبالرغم من قصر مدة حكمه الا انه استطاع ان بتصدى للإفرنج ويسترد منهم عكة وصور وصيدا وبيروت وقلعة الروم وبيسان وجميع الساحل(^).

وكان حاكم كفء، مهيب ، شديد البأس ، إذ يقول ابن أياس: " كان بطلاً لا يكل عن الحروب

ليلاً ، ونهاراً ، ولا يعرف من أبناء الملوك من كان يناظره في العزم والثجاعة والإقدام" (9).

$$
\text { r- السلطان الناصر محمد بن قلاوون(r بq }
$$

هو محمد بن قلاوون بن عبد الله الصالحي أبو الفتح من كبار ملوك الدولة القلاوونية ، اعتلى على عرش داث

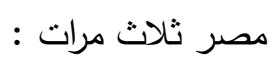

-السلطة الأولى استمرت عاما واحداً( (ب9-79 7هـ)

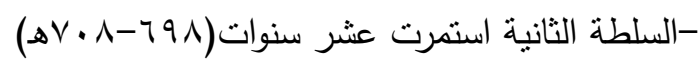

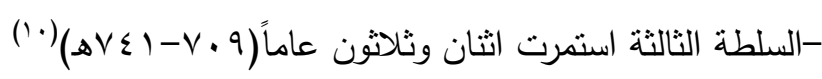

لعل ابرز ما تميز به فترة حكمه وخاصة الثانية بالفتن والاضطرابات اما الفترة الثالثة بالاستقرار ، إذ تنكن من القضاء على الفتن والدسائس ونعمت البلاد في عهده بأطول فنرة استقرار وعُدت من ازهى عهود

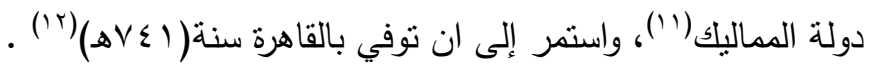

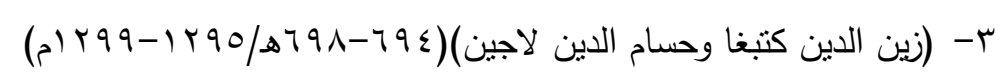

ولي السلطة زين الدين كتبغا وحسام الدين لاجين بعد ان اغتصباهما من الناصر محمد بن قلاوون

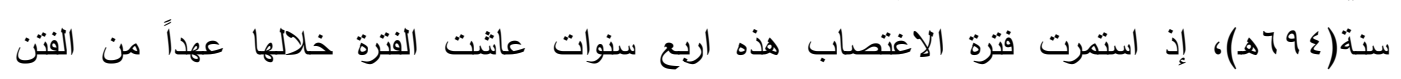

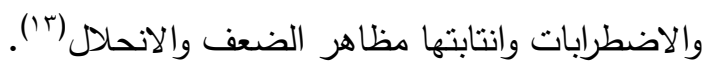




$$
\text { أولاد الناصر محمد وأحفاده(1) }
$$

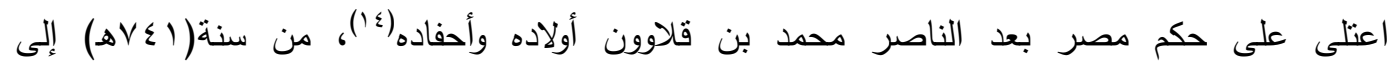

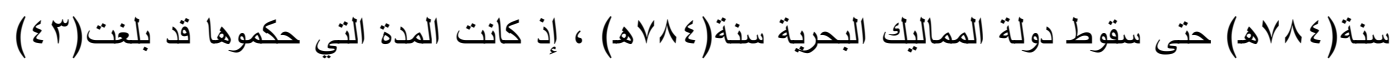

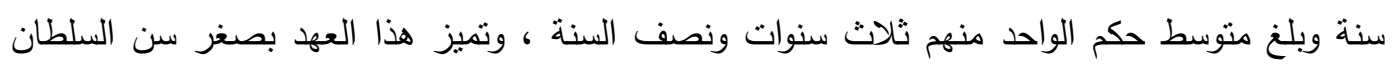

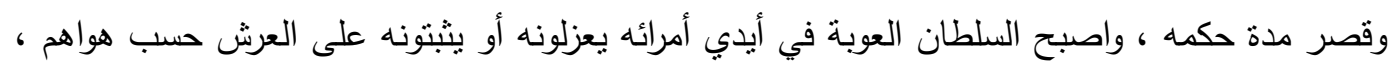
فاضطربت أحوال البلاد وكثرت الفتن (10).

\section{الحالة الفكرية والعلمية : - n}

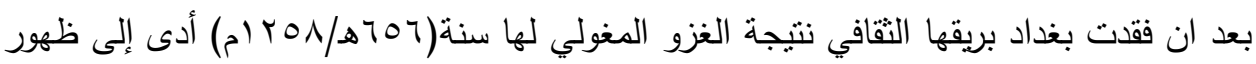
مراكز للحركة العلمية والثقافية في مصر والثشام مما ساعد على اجتذاب كثثر من العلماء للهجرة اليهماء وقد هاجر من أهل الأندلس إلى مصر (1).

لعب سلاطين المماليك دوراً فعالاً في تتشيط الحركة العلمية في مصر، إذ ساعد هذا الدور على العلى

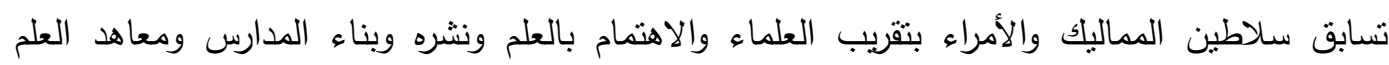

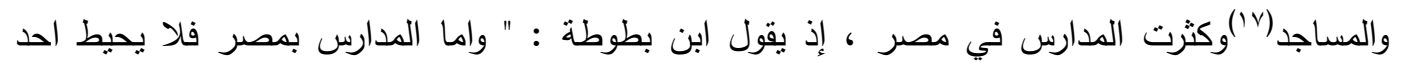

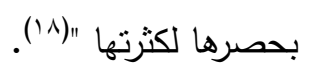

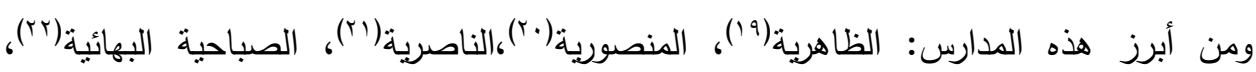

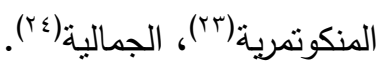

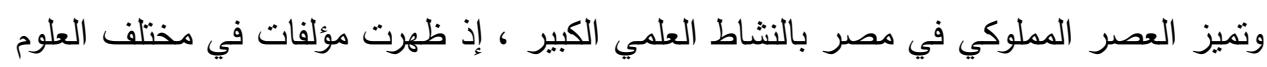

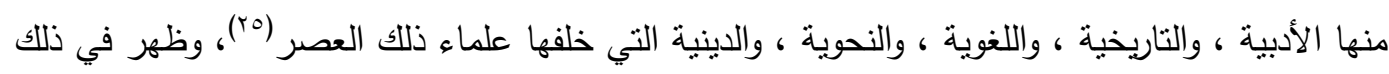

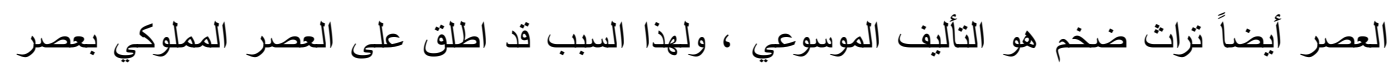

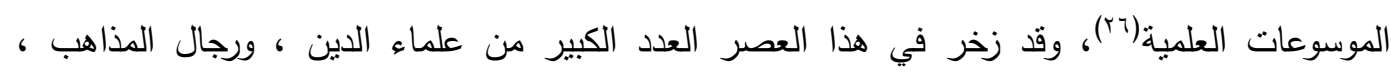

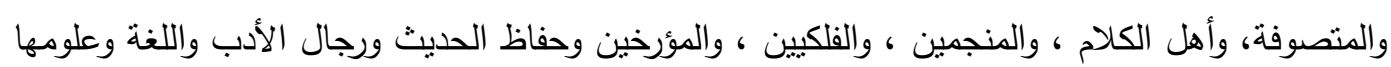
، ومن ابرزهم : 


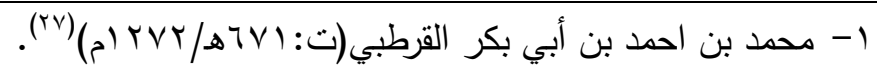

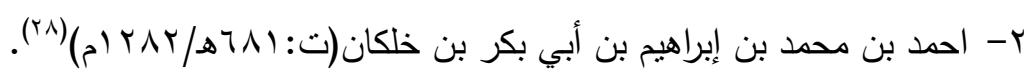

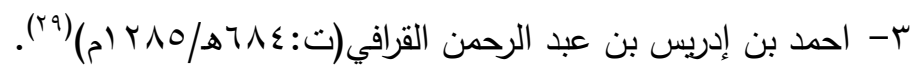

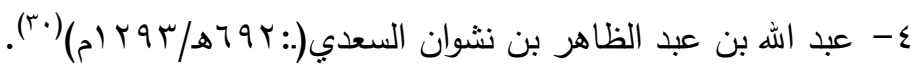

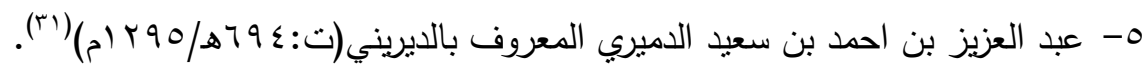

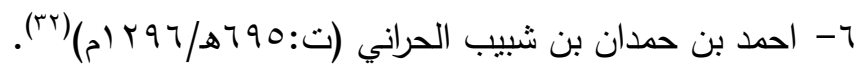

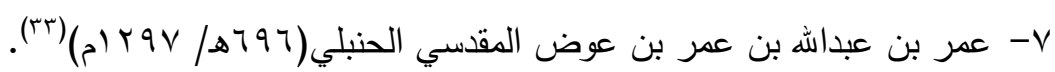

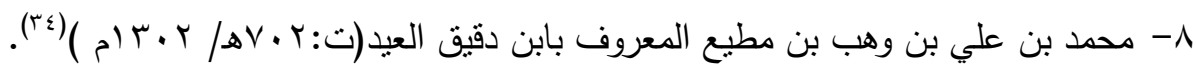

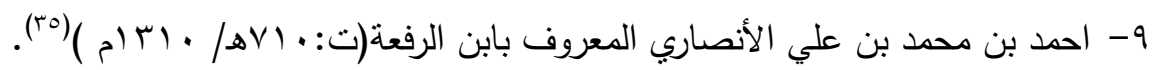

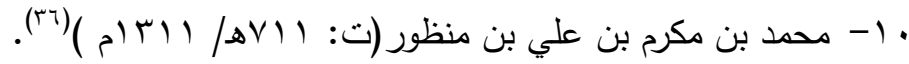

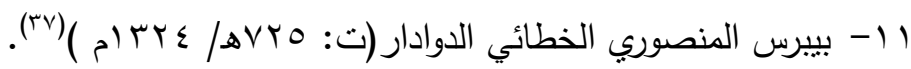

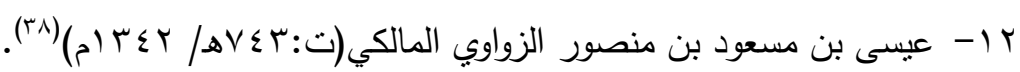

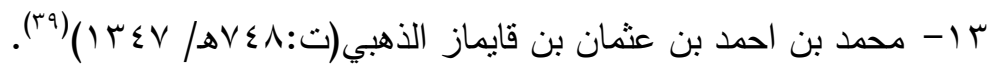

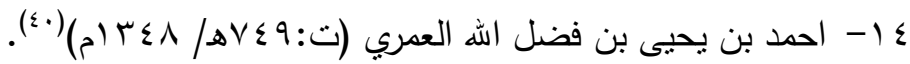

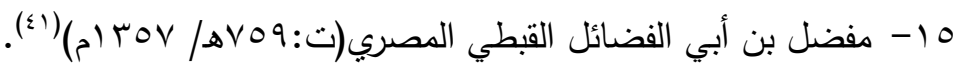

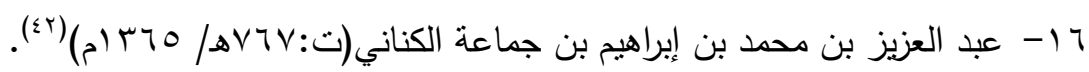

من خلال ما تقدم يتضح ان الوضع السياسي في عصر مغلطاي لم يكن مستقراً فقد امتاز

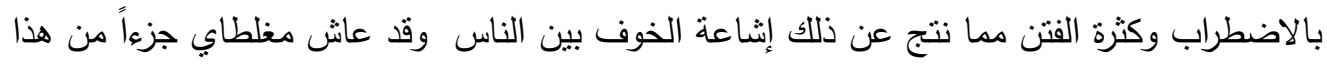

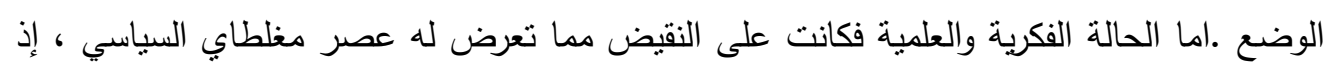
نشطت حركة التأليف في حينها وبرزت مؤلفات في علوم شتى لمفكرين وعلماء ذلك العصر ومن بينهم الحافظ مغلطاي. 
ثانيا : سيرة وحياة مغلطاي

\section{اسمه ونسبه :}

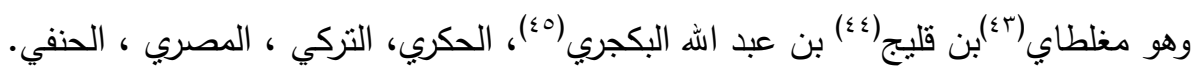

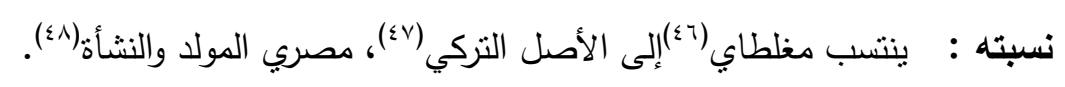
كنيته ولقبه : تشير المصادر التاريخية ان مغلطاي كان يكنى ب(أبي عبد اله)(9؛). اما لقبه فكان بلقب بـ(علاء الدين)(0) ، وب(الحافظ)(0).

مذهبه : كان الحافظ مغلطاي ينتسب إلى المذهب الحنفي بدليل انه تتلمذ على يد شيوخ الدذهب الحنفي (Or) (ملهن)

مولده ونشأته : تشير المصادر التاريخية ان مغلطاب(رحمه الله) ولد في جامع قلعة الجبل(or) في

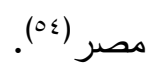

وقد وقع الخلاف في سنة ولادنه وهم على ثلاثة أقوال:

$$
\begin{aligned}
& \text { القول الأول: ذهب إلى ان ولادته كانت في سنة(1/97هـ/ • ب (م)(00). }
\end{aligned}
$$

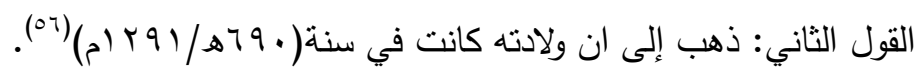

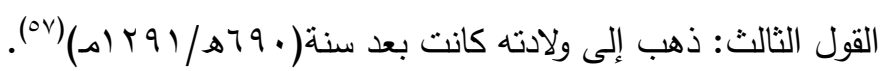

والراجح من هذه الأقوال هو القول الأول(في سنة 9 الهـهـ وهو ما ذكره الحافظ مغلطاي بنفسه عندما سأله الحافظ العراقي عن ولادته فقال: انه في سنة تسع وثمانين (ه). 
اما نثأته : نشأ الحافظ مغلطاب في مصر وكان مقامه بالقاهرة وحينها كانت مدينة القاهرة تزخر بكثرة علماءها ، ومحدثيها ، ومؤرخيها ، وفقهاءها مما سنحت له الفرصة للقاء بهم وملازمتهم (09)، والتي أعطته

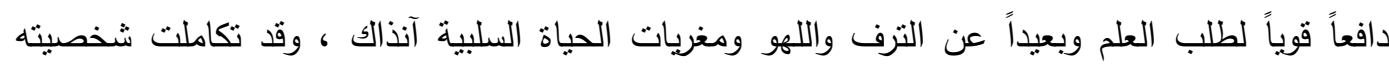

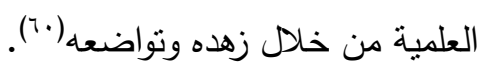

\section{مكانته العلمية وآراء العلماء فيه :}

تبوأ الحافظ مغلطاي (رحمه الله) مكانة علمية مرموقة أهلته ان يكون في الصدارة في العلم

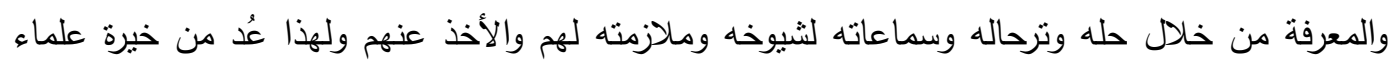
القرن الثامن الهجري في الديار المصرية، وقد ابدى العلماء آرائهم بحقه :

قال عنه ابن قاضي شهبه : " ولي مثيخة الحديث بالظاهرية ، والقبة الركنية وغيرهما وصنف التصانيف الكبرى غالبها مآخذ على أهل اللغة وأصحاب علوم الدين كابن ماكولا والخطيب والمزي واجل منهم وأصحاب السير وشرح السنن"(1). ويقول عنه الحافظ ابن حجر العسقلاني: " الإمام العلامة"(Tr). وفي موضع أخر يقول عنه: " شيخ الثيوخ "(זٓ). وفي موضع أخر يقول عنه أيضاً: " انتهت إليه رئاسة الحديث في زمانه"(؟َ).

وقال ابن تغري بردي بحقهِ : "وكان له اطلاع كبير ، وباع واسع في الحديث وعلومه وله مشاركة في فنون عديدة تغدده الله برحمته "(70).

وقد سأل الحافظ العراقي عن أربعة تعاصروا أيهم احفظ : مغلطاي ، وابن كثير ، وابن رافع ،

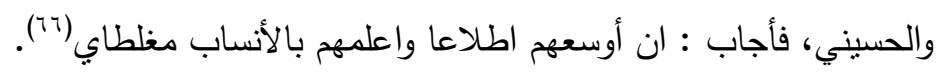
وقال السيوطي بحقهِ : " كان عارفاً بفنون الحديث"(TV). 
العـــــــدد الثاني والعشرون

\section{مجلــــة كلبـــــة التربيــــة}

وقال الشوكاني: " اكثر من القراءة بنفسه والسماع وكتب الطبقات ولازم الجلال القزويني ودرس

بالقاهرة بالحديث وصنف تصانيف منها شرح البخاري وذيل المؤتلف والمختلف ، والزهر الباسم في السيرة النبوية ، وسمع من الدمياطي ، ومن تقي الدين ابن دقيق العيد بالكاملية سنة(r • Vه) وله ذيل عن تهذيب ودئ الكمال في قدر الأصل"(^^).

: وفاته

اتفقت المصادر التاريخية على ان وفاة الحافظ مغلطاي كانت في شهر شعبان سنة(r VIه)(T9) ، الا انها اختلفت في تاريخ اليوم الذي توفي فيه ، وهي على قولين:

القول الأول : ذهب إلى ان وفاته في اليوم الرابع عشر من شعبان(•) . القول الثاني: ذهب إلى ان وفاته في اليوم الرابع والعثرين من شعبان ('ا).

وارجح الأقوال هو القول الثاني لانهم اقرب للحدث من غيرهم بالإضافة إلى انه قول الجماعة واله اعلم . 
ثالثاً : مكونات ثقافة مغلطاي

تتطلب وظيفة العمل بالحديث النبوي الثريف التتقل والترحال لملاقاة الحفاظ والاستماع اليهم

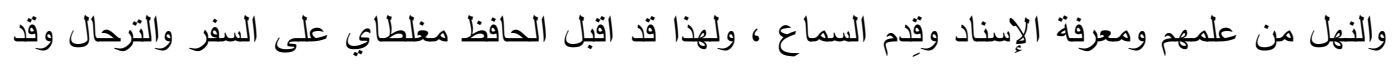

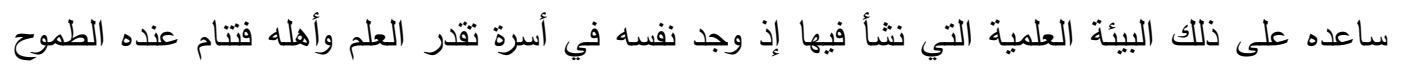

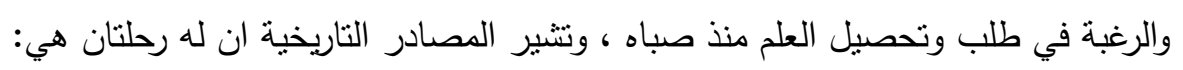

1- رحلته إلى بلاد الثام ، والتي مكنته من توليه وظيفة التدريس في مدارسها وإدارة الحلقات في

جوامعها (vr)

ץ- رحلته إلى القاهرة ، مكنته من تدريس الحديث فيها ، وذكر انه سمع من الدمياطي، ومن ابن

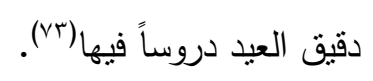

شيوخه :

تتلمذ الحافظ مغلطاب على عدد من العلماء في مختلف العلوم ، الفقه، والحديث ، والنحو ، وعلوم

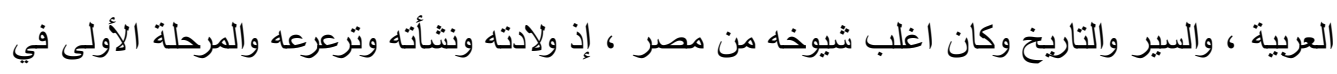
طلبه للعلم ، وطبيعة الدراسة هنا لا تسمح لنا بذكر جميع شيوخه بل إننا سنكتفي بترجمة وجيزة لأبرز شيوخه وهم :

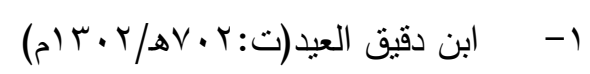

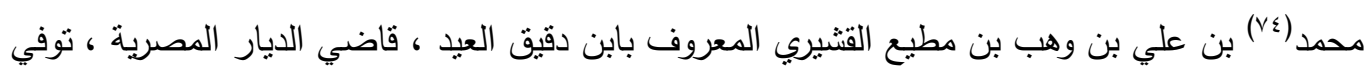

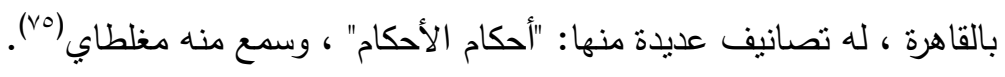

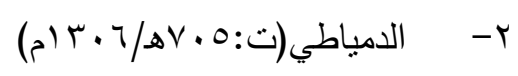




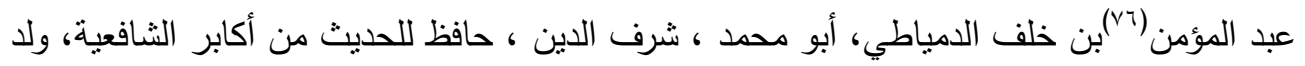

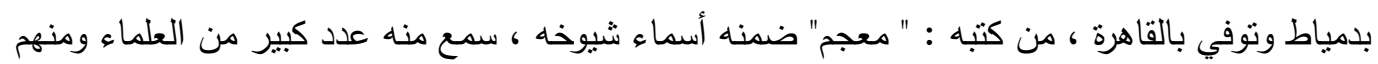

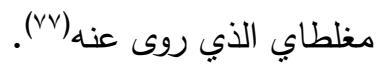

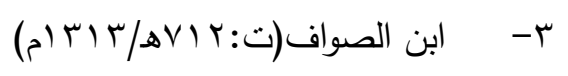

علي (r^بن نصر الله بن عمر أبو الحسن القرشي المصري بن الصواف الثافعي، وكان مغلطاب من الذين سمعوا منه بن (va).

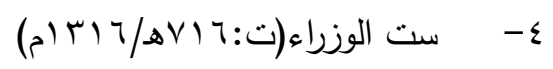

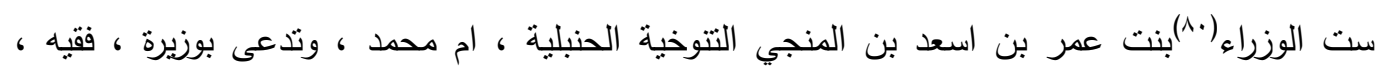

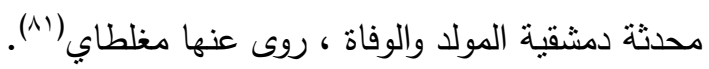

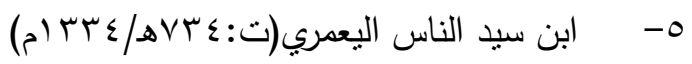

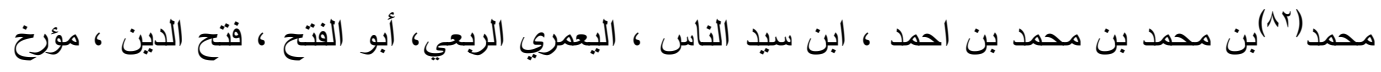

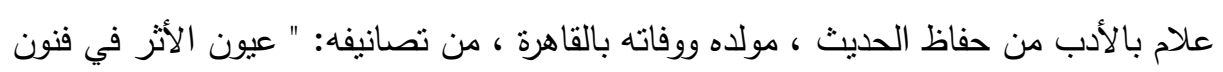

المغازي والثمائل والسير" ، قام مغلطاي بتخريج احد كتبه وهو " تحصيل الإصابة في تفضيل

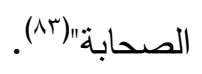

تلاميذه :

بعد ان تلقى الحافظ مغلطاي العلوم على يد كثير من الثيوخ ، أقبل عليه الكثير من طلاب العلم

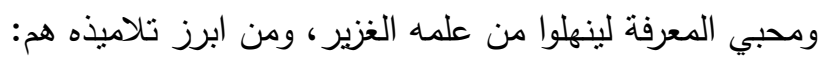

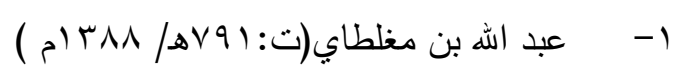

عبد اله(ء) بن مغلطاي بن قليج بن عبد الله ، أبو بكر ، جمال الدين التركي ، تتلمذ على يد أبيه 
مغلطاي الذي اسمعه صحيح البخاري على شيوخه(^).

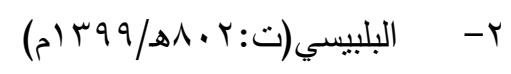

إسماعيل(1/)بن إبراهيم بن محمد الكناني البلبيسي ، مجد الدين ، قاض حنفي من الفضلاء من أهل بلبيس في مصر ، من كتبه: "قدس الأنوار" ، ذكره السخاوي انه تخرج بالحافظ مغلطاي(Av).

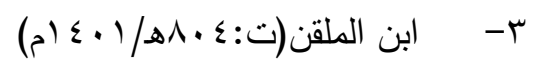

عمر (^) بن علي بن احمد الأنصاري ، الثافعي ، سراج الدين ، أبو حفص ، ابن النحوي، المعروف بابن

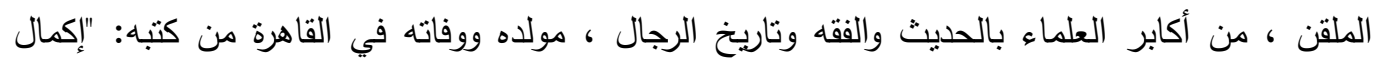

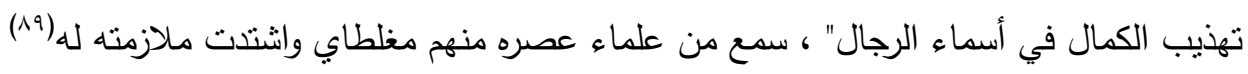

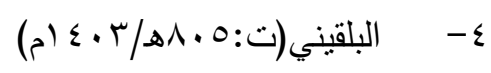

عمر (9) بن رسلان بن نصير بن صالح الكناني، العسقلاني الأصل ثم البلقيني المصري الثافعي أبو

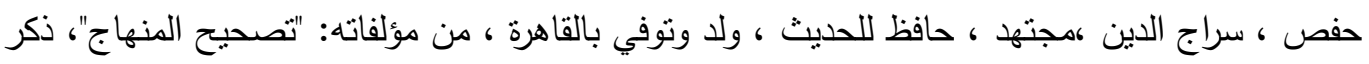

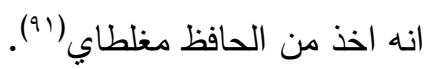

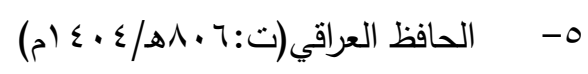

عبد الرحيم(جr) بن عبد الرحمن ، أبو الفضل ، زين الدين ، المعروف بالحافظ العراقي، من كبار حفاظ

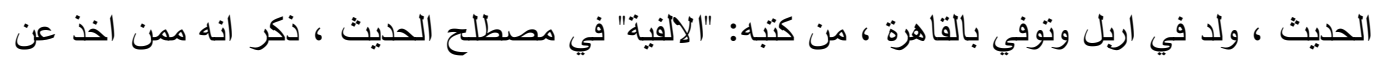

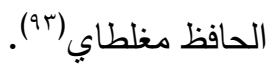


الوظائف والأعمال التي قام بها :

أقبل الحافظ مغلطاي على وظيفة التدريس وتعد هذه الوظيفة من الوظائف السنية(؟9التي نولاها في الجوامع والمدارس ، فتولى التدريس والإقراء ومثيخة الحديث في كثير من تلك المؤسسات العلمية،

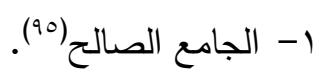

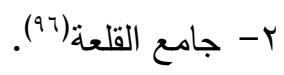

r- ( ) جامع آق سنقر (av).

اما المدارس التي درس فيها الحافظ مغلطاي هي:

$$
\begin{aligned}
& \text { 1- المدرسة الصالحية(9^). } \\
& \text { r- المدرسة الناصرية(199. } \\
& \text { ك- المدرسة المهذبية(..'(1). } \\
& \text { ع- المدرسة المجدية(1 (1). }
\end{aligned}
$$

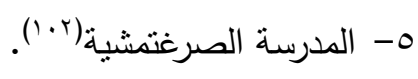

$$
\begin{aligned}
& \text { צ- المدرسة الظاهرية(r +1). }
\end{aligned}
$$

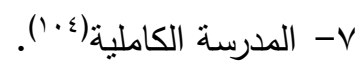

$$
\begin{aligned}
& \text { - }
\end{aligned}
$$

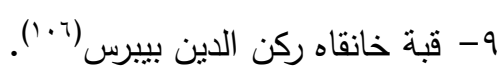


اثرى الحافظ مغلطاب بنشاطه الثقافي والفكري الحياة الثقافية للإسلام بمصر وغيرها من الأمصار الإسلامية مما انعكس اثره على إنتاجه العلمي، ويقول ابن رجب عند ترجمته لمغلطاي: " وكتب بخطه كثيراً

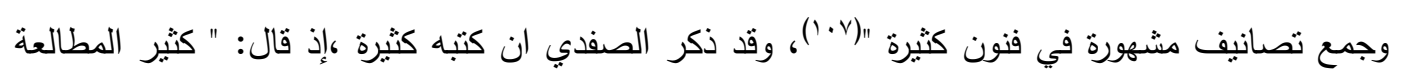

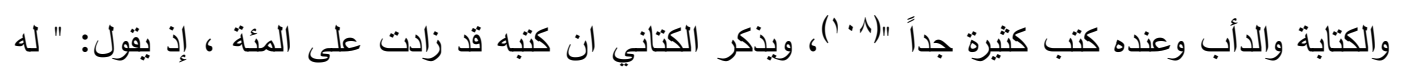

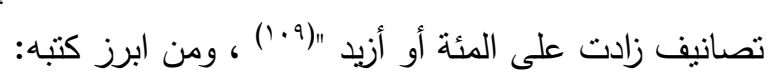

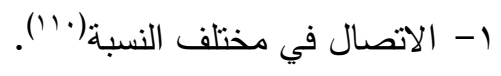

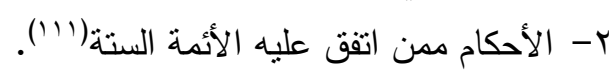

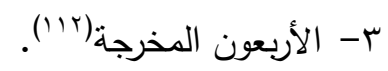

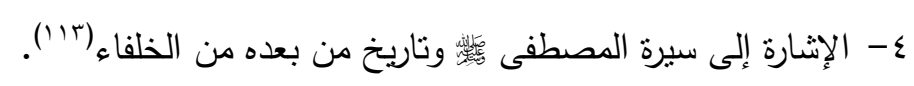

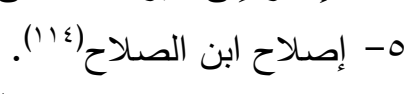

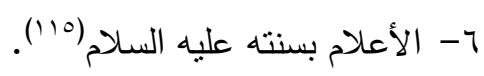

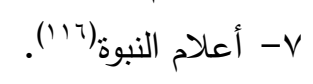

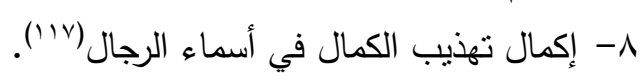

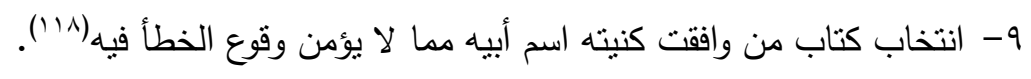

$$
\begin{aligned}
& \text { • } 1 \text { - أوهام الأطراف(199). }
\end{aligned}
$$

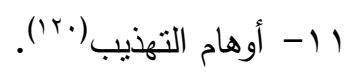

$$
\begin{aligned}
& \text { rا }
\end{aligned}
$$

rا

ـ ا - التراجم الساقطة من كتاب إكمال تهذيب الكمال لمغلطاي(rrrir).

$$
\begin{aligned}
& 10 \text { - } 1 \text { - ترتيب صحيح ابن حبان (عَr) . }
\end{aligned}
$$

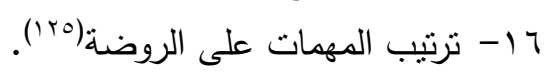

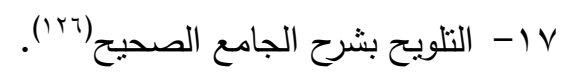

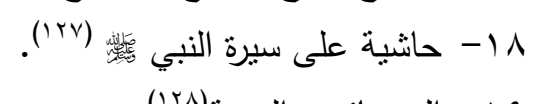

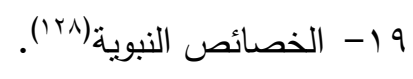


• r- الدر المنظوم من كلام المصطفى المعصوم(191).

(Y- ذيل على تكملة الإكمال لابن نقطة(·r)").

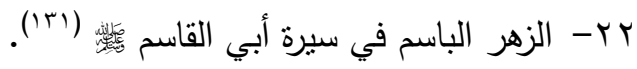

rr- فتوح إفريقية من المهدية إلى ارض المغرب(rrri).

گ צ- فيمن عرف بالله تعالى (rrr).

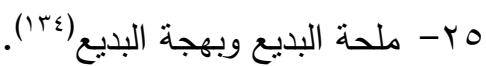

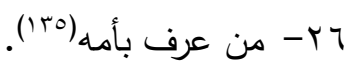

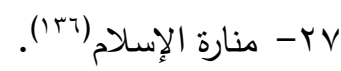

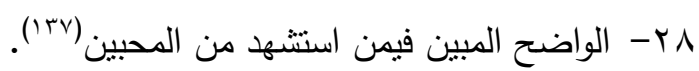


القسم الثاني: دراسة كتاب "مختصر تاريخ الخلفاء" للحافظ مغلطاي

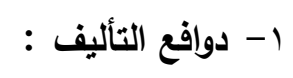

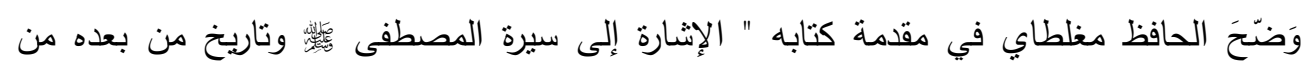

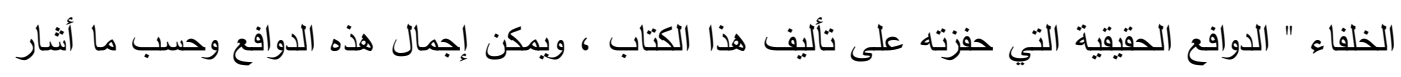

$$
\begin{aligned}
& \text { إليها مغلطاي في مقدمة كتابه بما يلي: } \\
& \text { أ- الاستجابة لرغبة احد القضاة : }
\end{aligned}
$$

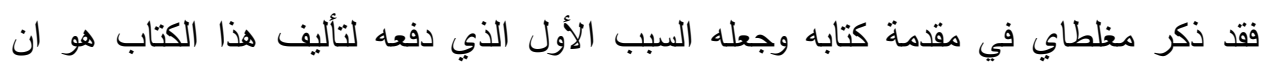

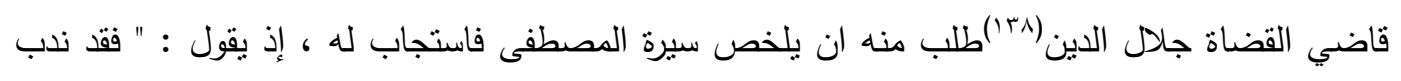

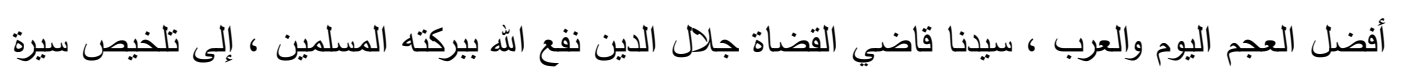

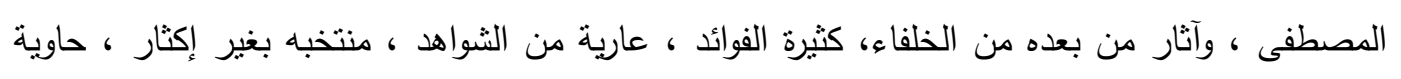

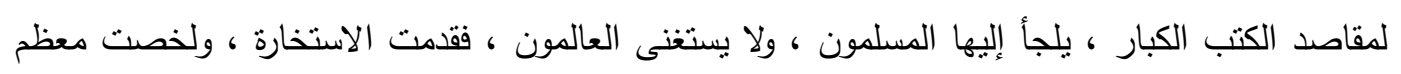

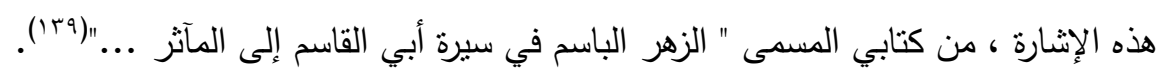

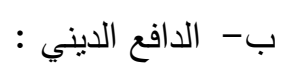

كما ان الدافع الديني لعب دوراً في تأليف هذا الكتاب ، إذ قال مغلطاي : " ... واله اسأل ان يجعله لوجهه

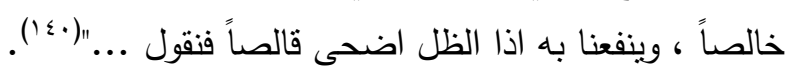

\section{توثيق اسم الكتاب ونسبته للمؤلف :}

بعد التحري والتدقيق في فهارس الكتب والمصادر التاريخية لم نجد كتاباً بعنوان " مختصر تاريخ

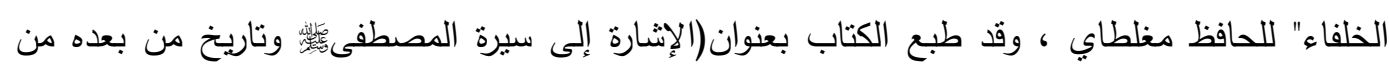

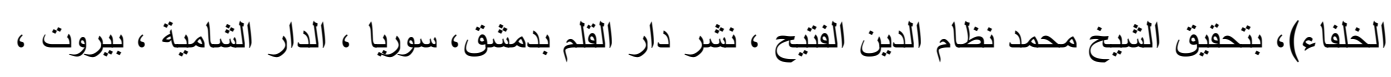




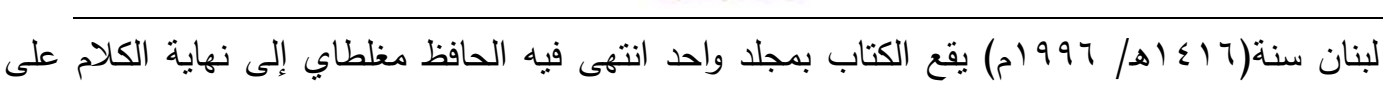

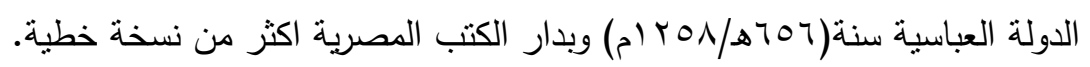

يتضح من خلال ذلك ان الكتاب هو كتاب واحد والذي أنى من بعده من المحققين قسم الكتاب

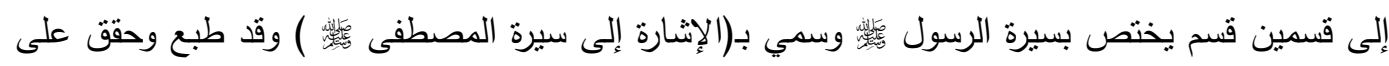

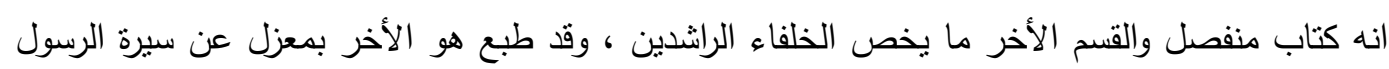
•

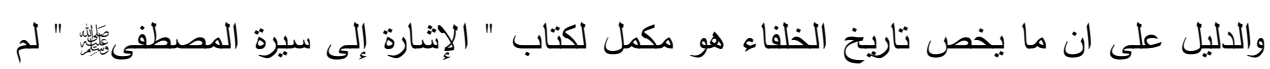

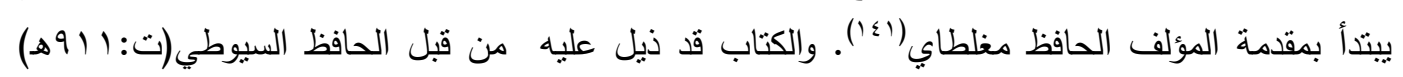

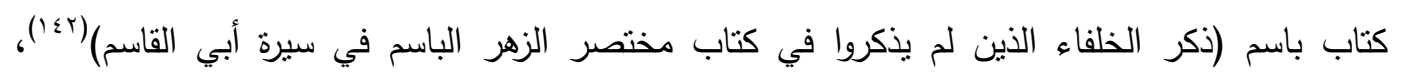

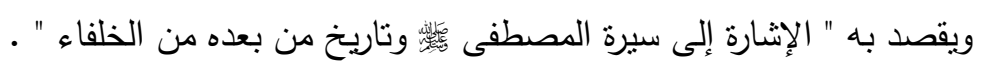

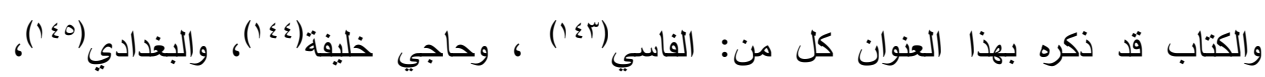

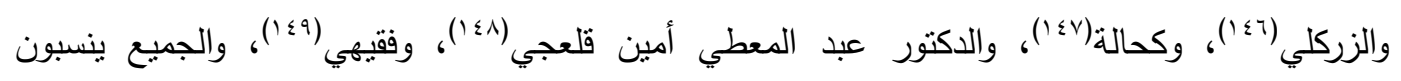
الكتاب للحافظ مغلطاي.

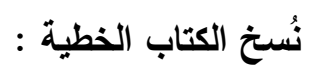

توجد(T () نسخة خطية موزعة على مكتبات العالم وكما يلي:

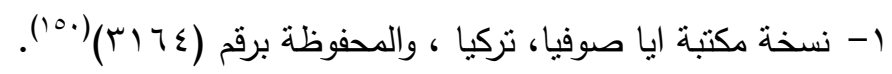
r- نسخة مكتبة فيض اله ، استانبول، والمحفوظة برقم (•7 ـ (1) (101).

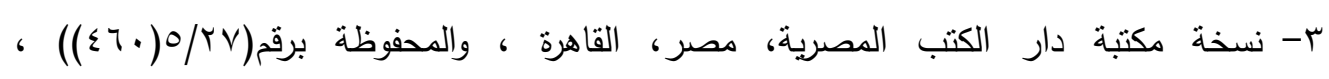

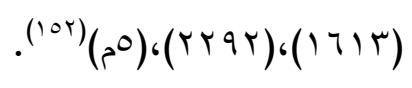

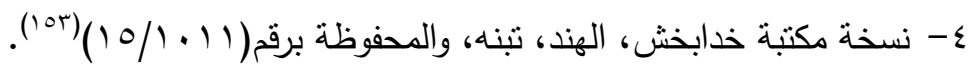

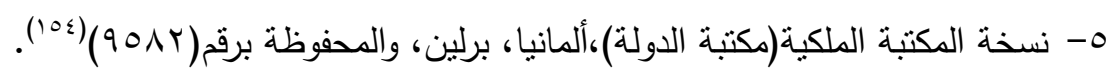

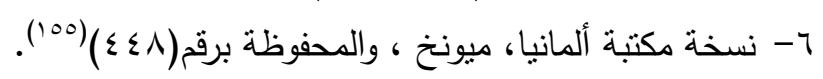

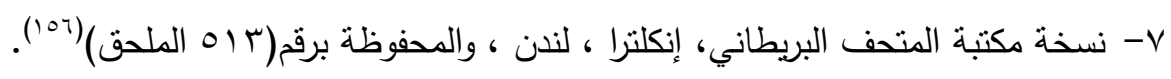

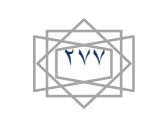


1 - نسخة مكتبة الإسكندرية(البلدية)همصر ، الإسكندرية، والمحفوظة برقم(ب تاريخ)(10v).

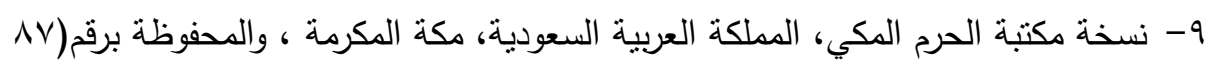

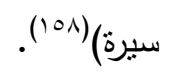

• 1 - نسخة مكتبة الرئاسة العامة لإدارات البحوث العلمية والإفتاء ، المملكة العربية السعودية، الرياض،

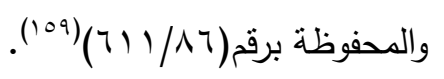

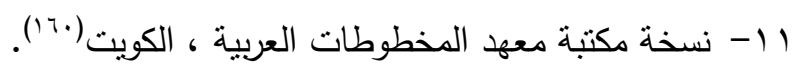

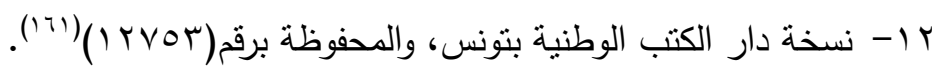

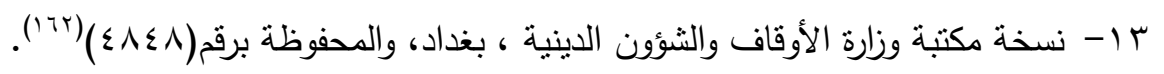

\section{تاريخ نَستخ الكتاب}

تشير المعلومات المتوفرة لدينا إلى ان نسخة دار الكتب المصرية هي بخط العلامة كمال الدين أبي البقاء محمد بن موسى الدميري صاحب كتاب " حياة الحيوان الكبرى" المتوفي سنة(^ • ^هـ) ، وقد فرغ

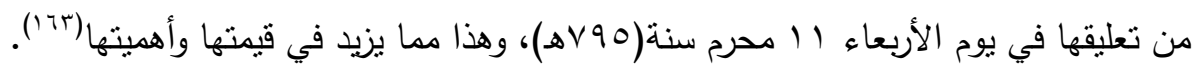

: تشرات الكتاب

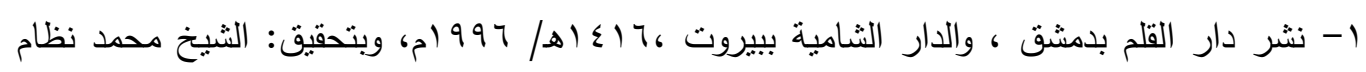
الدين الفتيح في مجلا بعنوان(الإشارة إلى سيرة المصطفى ، وتاريخ من بعده من الخلفاء).

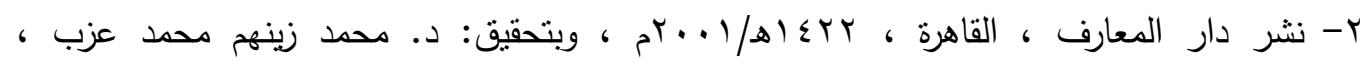
بعنوان(مختصر السيرة النبوية) والكتاب اقتصر فيه على السيرة النبوية ، انتهى الكلام فيه ابتداء • التاريخ

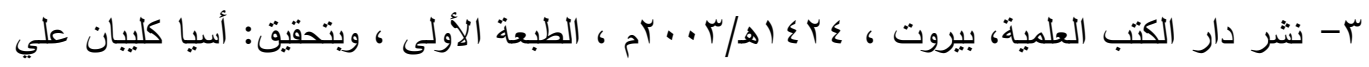
بارح ، الكتاب يبتدأ من ابتداء التاريخ ، ولا توجد فيه مقدة المؤلف (مغلطاي). 
يُعد كتاب " مختصر تاريخ الخلفاء " من الكتب المهمة بمكان ، إذ انه صور لنا حياة الخلفاء

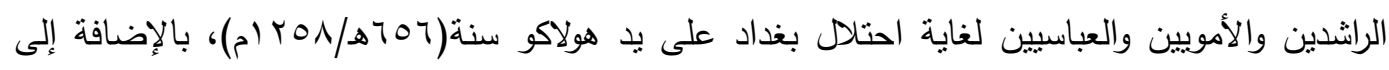

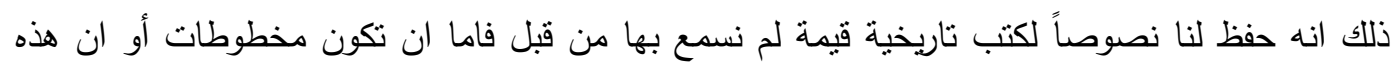

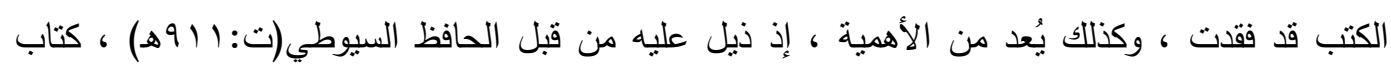

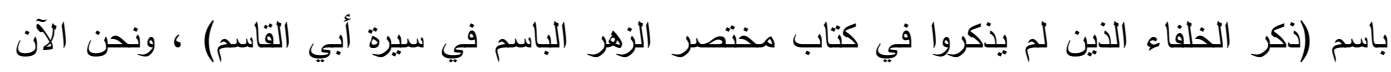

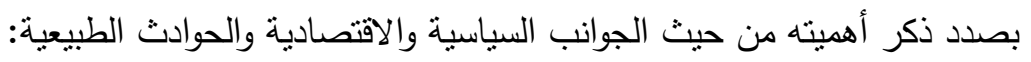

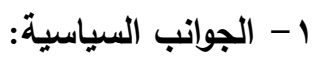

وردت في كتاب "مختصر تاريخ الخلفاء" نصوص تصور الحالة السياسية للبلاد العربية هذا ما

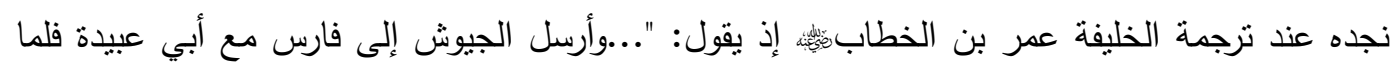
قتل يوم الجسر وأرسل إلى ابن أبي وقاص جريراً والمثنى بن حارثة فكانت وقعة أجنادين... ويوم فحل ،

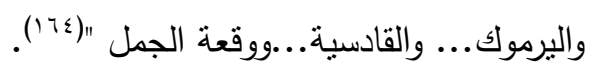

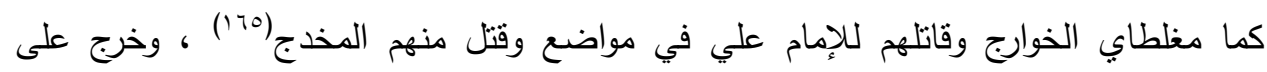

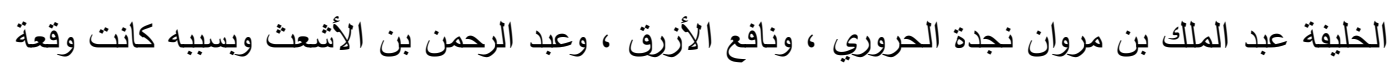

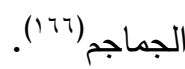

كما أجاد مغلطاي حين أورد يوم الحرة(17\%)،ووقعة عين الوردة ، ووقعة عين الخازر(11).

وأثار مغلطاي إلى ذكر خروج بابك الخرمي في خلافة المأمون(199)، وخروج صاحب الزنج بالبصرة في

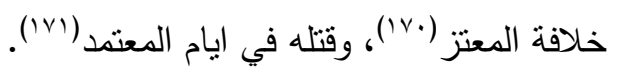

كما أورد تحركات القرامطة في زمن المعتد (Yr) .وخروج علوي يلقب بالنافع باذربيجان(Yr)

وذكر خروج الديلم على أصبهان وأميرهم أبو الحسن علي بن بويه الملقب عماد الدولة في عهد القاهر (IV؛) وخرج وخروج الباطنية في عصر المسترشد (1V0). 
العــــــــد الثاني والعشرون

مجلــــة كليــــة التربيــــة

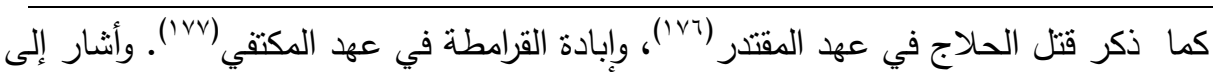

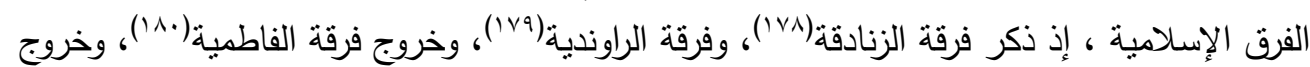

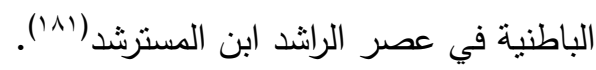

ولم يغفل من ذكر محنة خلق القرآن في عصر المأمون(rAl). كما أجاد حين ذكر الفتوحات منها

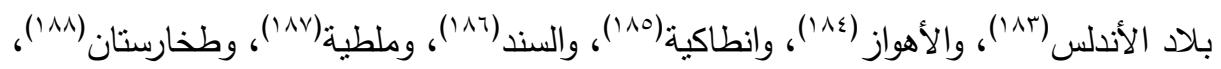

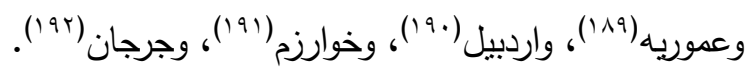

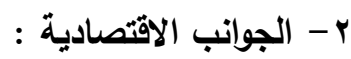

وردت معلومات عن الجانب الاقتصادي ، إذ فال مغلطاي: " أول من ضرب السكة عبد الملك بن

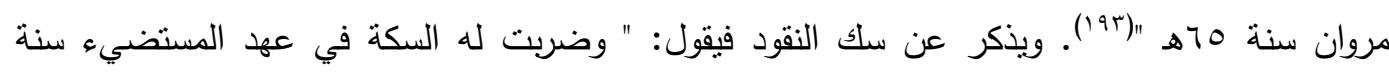

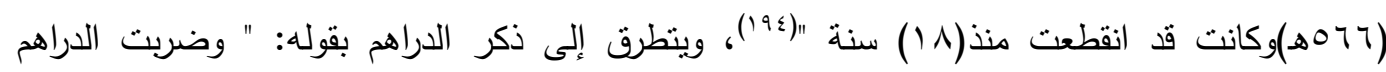
الراضويه في عهد الراضي باله سنة بوسهـ "(190). ب - الكوارث الطبيعية

وردت معلومات عن سيل جحاف(191)، ووقع الطاعون بالثام(197)، ووقع الطاعون في عهد

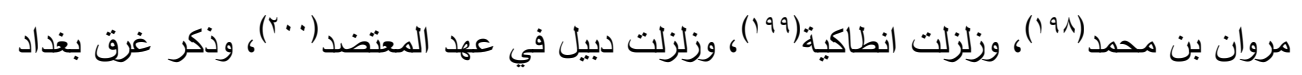

في عهد القائم(ب+r)، وأشنار في كتابه إلى ان السماء قد أمطرت دماً في اليمن(r+r). وأجاد مغلطاي حين ذكر الخسف الذي حصل بسمسياط ، ومرعش في عهد المستظهر (r.r). وذكر لنا أيضاً هلك ثلاثتون الفاً من الأفس بعد خسف القمر فأظلمت الدنيا إلى العصر ، وهبت ريح سوداء في عهد المعتضد(ع.+r). 
وصف عام للكتاب ومحتواه :

يُعد كتاب " مختصر تاريخ الخلفاء لمغلطاي(الئلهT) من الأهمية بمكان ، إذ يقدم لنا صورة

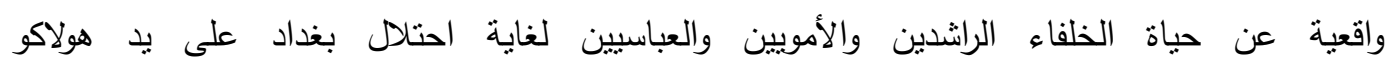

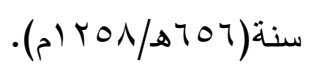

ومن خلال الاطلاع على مقدة الكتاب ومعرفة دوافع تأليفه يتضح لنا المنهج الذي رسمه

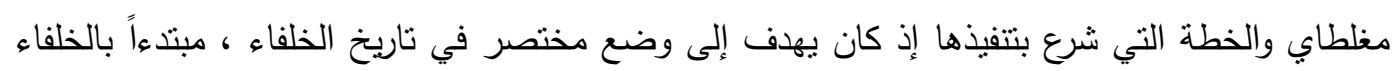

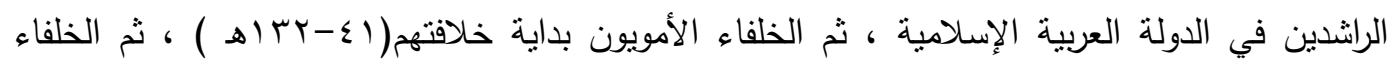

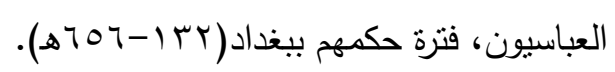

والكتاب الذي نحن بصدده يتألف من (9191) صفحة وقد وضع مغلطاب عناوين لمواضيعه

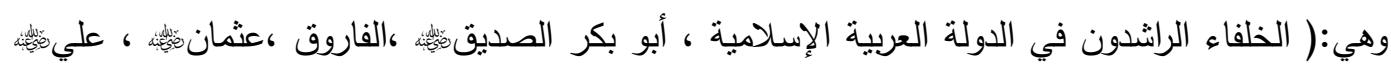

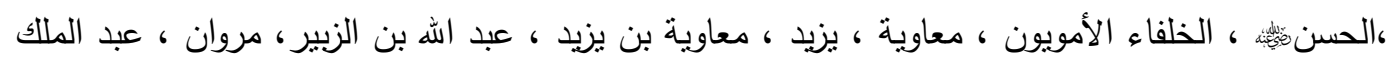

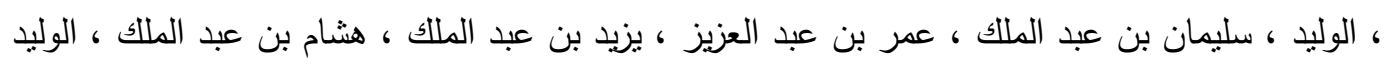

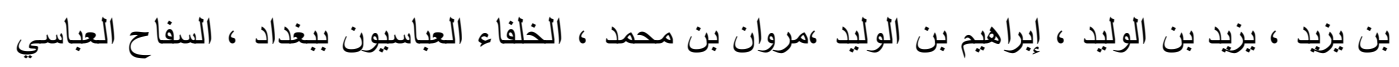

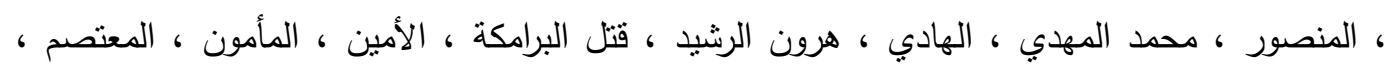

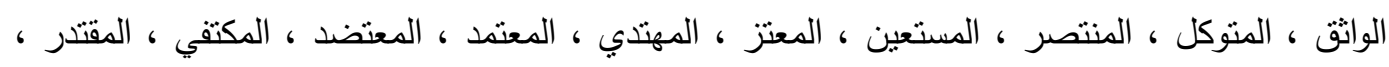

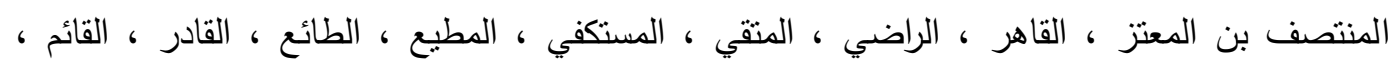

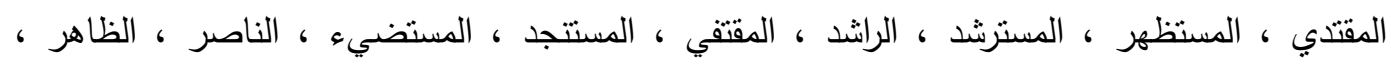

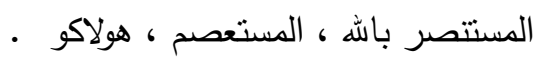


عناصر الترجمة :

يبدأ الحافظ مغلطاي عند ترجمته للخلفاء عادة بذكر اللقب ثم الكنية ثم الاسم هذا ما نجده عند

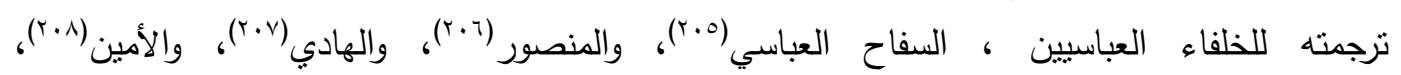

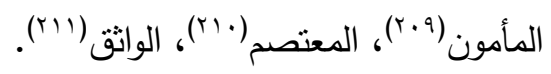

واذا وجد اكثر من كنية ذكرها هذا ما نجده عند ترجمته للخليفة عثمان صيّئن ،إذ يقول: "..أبو عبد

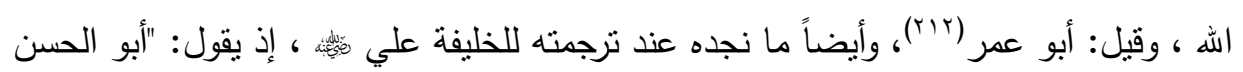

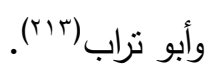

اعتاد الحافظ مغلطاي في بعض الأحيان بذكر الألقاب وجعلها عناوين هذا ما تم ذكره أعلاه ، وفي بعض الأحيان يجعل من الأسماء عناوين له هذا ما نجده عند ترجمته للخلافة الراشدة مثل: ابو بكر

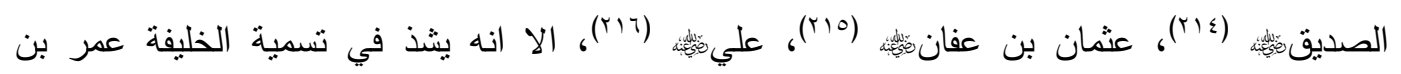

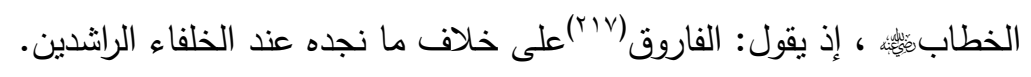

قلنا انه يذكر العناوين ثم البيعة هذا ما نجده عند أغلب الخلفاء ، ثم يذكر الكنية ، ثم الاسم

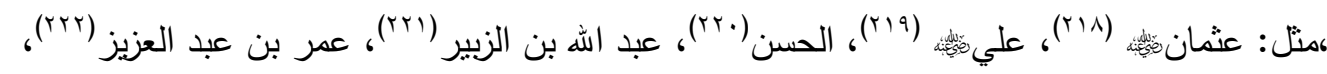

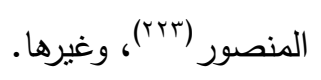

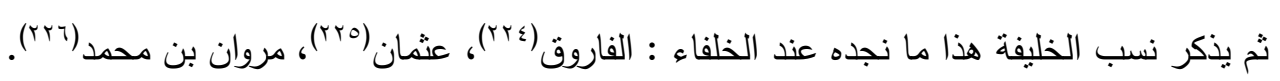
وفي بعض الأحيان يذكر لنا ناريخ البيعة والخلع هذا ما نجده عند الخلفاء: الراثد(rYr)،

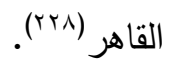

ثم ذكر مُدة خلافته هذا ما نجده عند أغلب الخلفاء ، إذ يقول عند ترجمته للخليفة عثمان بئئه : "

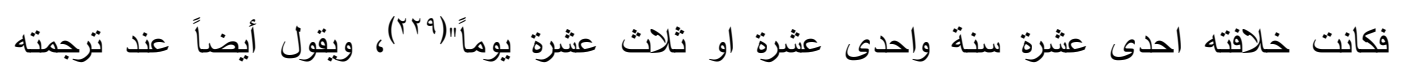
للمنصور ، إذ يقول: " احدى وعشرين سنة واحد عشر شهراً"(·rr). 
ثم اهتم الحافظ مغلطاي كثيراً بذكر تاريخ وفاة الخليفة ، إذ كان يذكر وفاته كاملاً في اليوم

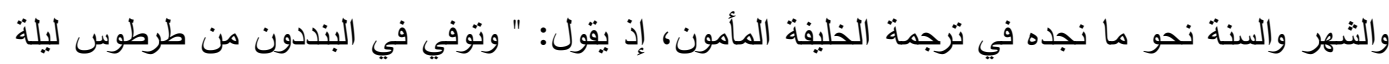

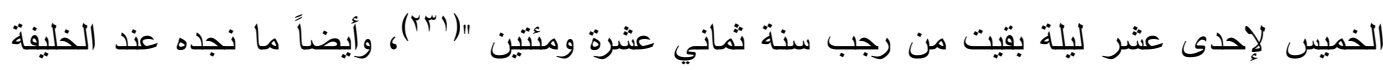

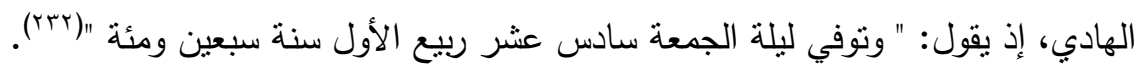

ويذكر وفاة الخليفة بالثهر والسنة فقط هذا ما نجده عند الخليفة هثام بن عبد الملك ، إذ يقول: "

$$
\text { وتوفي في شوال سنة خمس وعشرين ومئة "(Yrr). }
$$

واحيانا لا يذكر تاريخ الوفاة هذا ما نجده عند الخليفة إبراهيم بن الوليد ، إذ يقول: " وقتله مروان

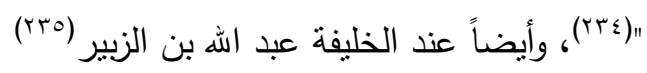

ونادراً ما كان يذكر سبب وفاة الخليفة نحو ما نجده عند الخليفة محد المهدي ، إذ يقول:" مات

مسموماً "(TrT)، وأيضاً عند الخليفة الوليد بن بزيد ، إذ يقول: " وقتل يوم الخميس للبلتين بقيتا من جمادي

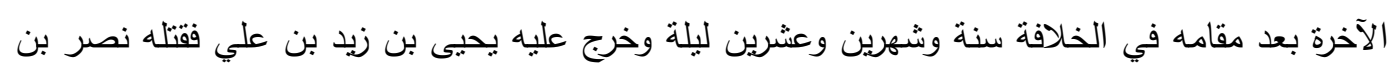

$$
\text { سيار "rrV (rT) }
$$

\section{منهجه في استخدام الموارد ونقل المادة التاريخية :}

الإسناد إلى المصادر : n l n

$$
\text { تتوعت طرق الحافظ مغلطاي في الإسناد إلى المصادر على النحو الاتي : }
$$

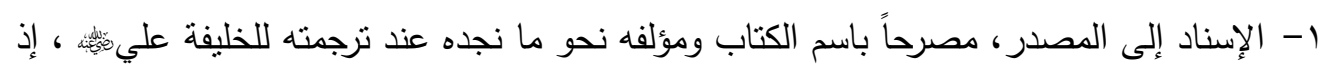

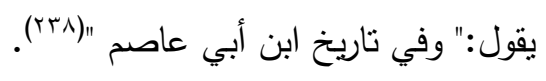

r- الإسناد إلى المصدر، مصرحاً باسم المؤلف دون تسمية كتابه نحو ما نجده عند نرجمته للخليفة

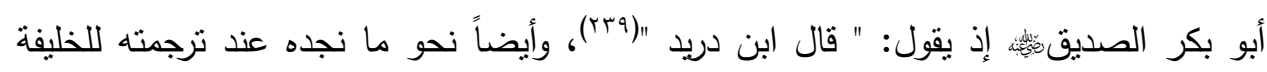

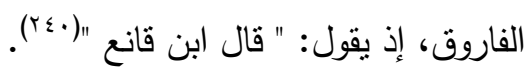




\section{العـــــــد الثاني والعشرون}

\section{مجلـــة كليـــة التربيـــة}

r- الإسناد إلى مبهم ، نحو ما نجده عند ترجمته للخليفة سليمان بن عبد الملك(1)، والخليفة مروان

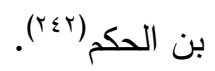

ع - إهمال الإسناد إلى المصدر، لم يصرح الحافظ مغلطاي في كثثر من تراجم الكتاب بمصادره نحو

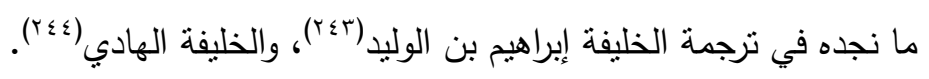

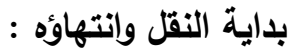

أهتم الحافظ مغلطاي باتباعه منهج واضح من حيث بداية نقولاته نحو قوله: " قال الذهبي"(؟0)، "

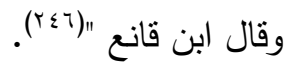

وفي بعض الأحيان يذكر ألفاظاً ندل على اقتباسها من مصدر معين ندل على انتهاء النص نحو قوله : "

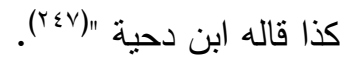
التصرف بالنص : n

لم يشر مغلطاي إلى التراجم التي لخصها أو اختصرها بشكل صريح فهو يتصرف في النسقين

$$
\text { الترتيبي والتعبيري المصاحبين لمنقوله من مصدره. }
$$

$$
\text { المنهج النقدي عند الحافظ مغلطاي : (المن }
$$

ويتضح من خلال اطلاعنا على كتاب" مختصر تاريخ الخلفاء " لمغلطاي انه اتبع منهجا في

التعليق على بعض الآراء والروايات ، عندما رد مغلطاي على ابن حزم ، إذ يقول : " وفيما قاله نظر "(r乏)

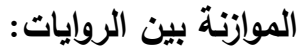

حرص الحافظ مغلطاي على القيام بموازنة بين المصادر نحو قوله:" فسمه بعضهم في كمثرى،

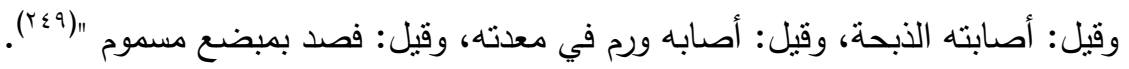


وأيضاً ما نجده في ترجمة الخليفة مروان ، إذ يقول: " وكان زنديقاً يعني الجعد ، وقيل: بل قيل له ، وبله

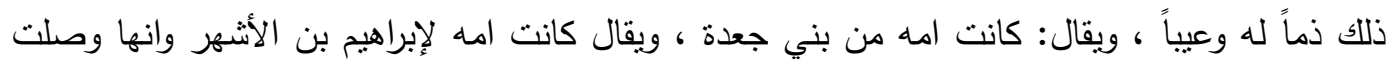

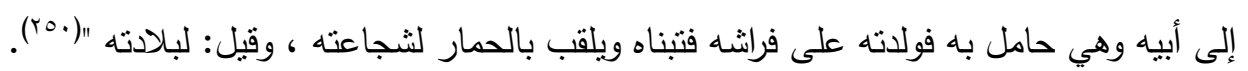

موارد الحافظ مظطاي في كتابه " مختصر تاريخ الخلفاء "

أولا : موارده المدونة :

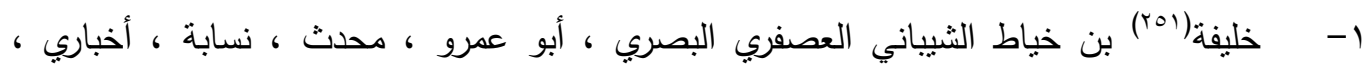

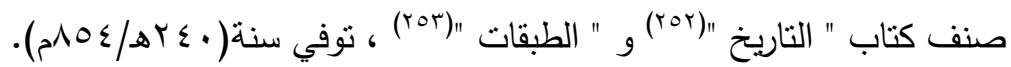
اقتبس مغلطاب منه نصاً واحداً( (ro\&) ، ذكره بلفظ " وخليفة بن خياط "(ro0).

r- يعقوب(ror) بن سفيان بن جوان الفارسي الفسوي ، أبو يوسف ، من حفاظ الحديث والمؤرخين r- - الكبار ، من أهل فسا من مصنفاته:" التاريخ الكبير"(ror)،" المعرفة والتاريخ "(rox) ، توفي بالبصرة

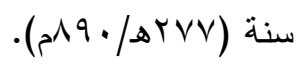

اقتبس مغلطاي منه نصاً واحداً (ro9) ، ذكره بلفظ " والفسوي "(rr) .

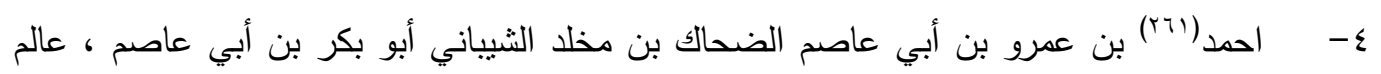

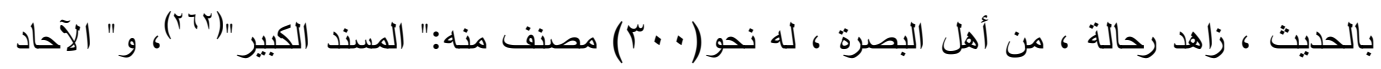

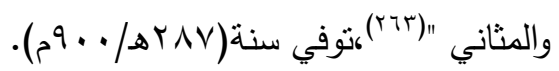

اقتبس مغلطاي منه نصاً واحداً( (Y؟)، ذكره بلفظ " وفي تاريخ ابن أبي عاصم "(Y00).

\begin{tabular}{|r|r|}
\hline & \\
\hline$(177)(1 / 1 / 1$ & $1 .$. \\
\hline
\end{tabular}


العــــــدد الثاني والعشرون

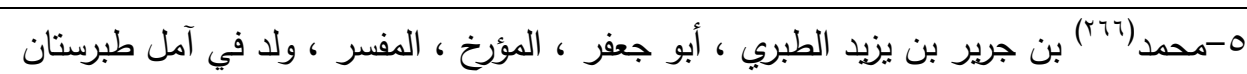

، واستوطن بغداد ، وتوفي بها ، من كتبه: " تاريخ الأمم والملوك "(Yrr) يعرف بتاريخ الطبري ، وهو

من نقات المؤرخين ، توفي سنة (• (اسه).

اقتبس مغلطاي منه نصاً واحداً( (rN) ، ذكره بلفظ : " وهذا حين الشروع في التاريخ الملخص من

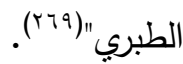

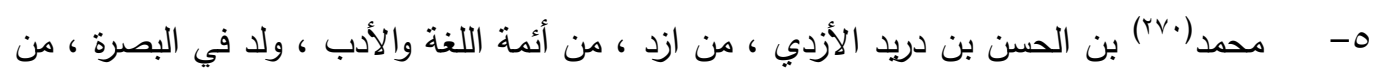

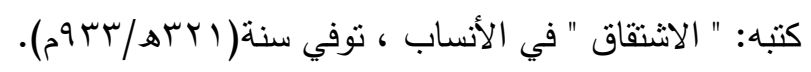

اقتبس مغلطاي منه نصاً واحداً( (YV) ، ذكره بلفظ " قال ابن دريد "(rVr).

צ- محمد(Yrr) بن احمد بن مزيد بن محمود ، أبو بكر الخزاعي البوشنجي، المعروف بابن أبي

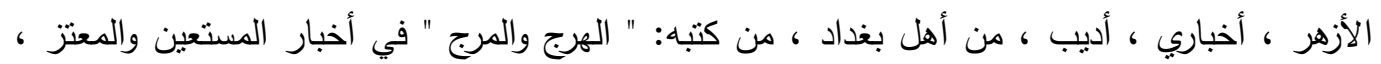

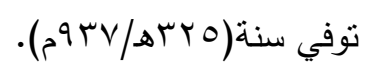

اقتبس مغلطاي منه نصاً واحداً(YV) ، ذكره بلفظ " وابن أبي الأزهر " (rVo).

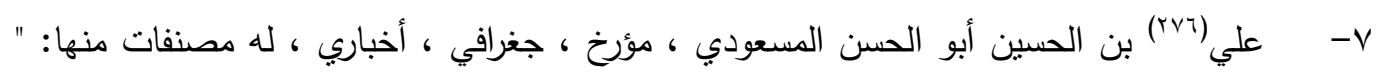
مروج الذهب ومعادن الجوهر" و " التتبيه والأشراف " ، نوفي في مصر سنة(7 ــهـ). اقتبس مغلطاي منه نصاً واحداً(YVV) ، ذكره بلفظ " والمسعودي"(YVA).

A- - عبد الباقي (rV9) بن قانع بن مرزوق بن واثق الأموي ، بالولاء ، البغدادي ، أبو الحسين ، قاض ، من حفاظ الحديث ، من كتبه: "معجم الصحابة" ، توفي سنة( اهـهـ/ بדوم).

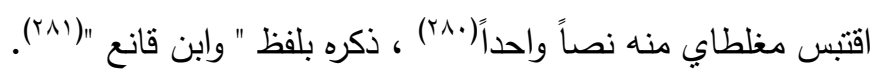


العـــــــد الثاني والعشرون

مجلـــة كليــــة التربيــــة

- - محمد(r^) بن حبان بن احمد بن حبان بن معاذ بن معبذ التميمي ، أبو حاتم البستي ، مؤرخ ، جغرافي ، محدث ، ولد في بست، تولى قضاء سمرقند ، من مصنفاته: " الثقاة " و" مشاهير علماء

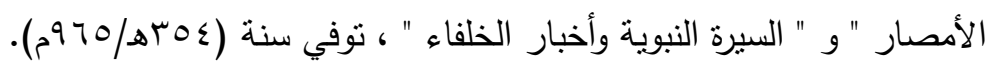

اقتبس مغلطاي منه نصاً واحداً(r^r) ، ذكره بلفظ " وابن حبان "(؟^^).

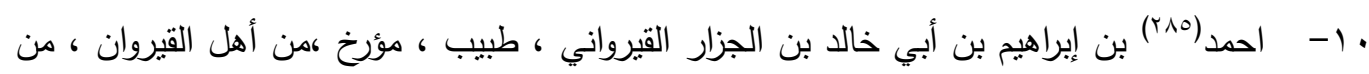

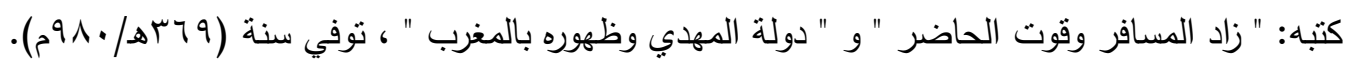
اقتبس مغلطاي منه نصاً واحداً(rAT) ، وذكره بلفظ " وابن الجزار "(YNV).

1) - احمد(YMA) بن محمد بن يعقوب بن مسكويه ، أبو علي ، مؤرخ ، أصله من الري وسكن أصفهان وتوفي بها ، انتخل بالفلسفة والكيمياء والمنطق مدة ، ثم ولع بالتاريخ والأدب والإنشاء ، وكان قيماً على بلى بن

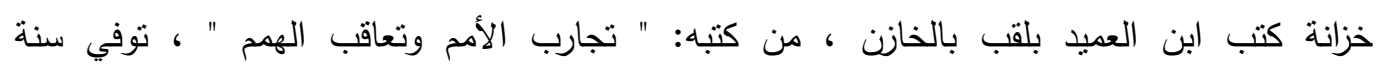
$\cdot(م) \cdot\left(\Delta \leq Y_{1}\right)$

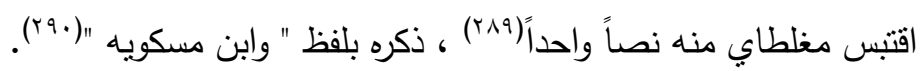

r ا- - علي (19) بن احمد بن سعيد بن حزم الظاهري ، أبو محمد عالم بالأندلس في عصره، واحد أئمة

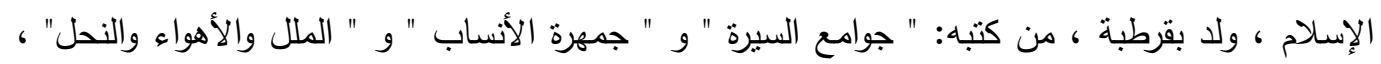

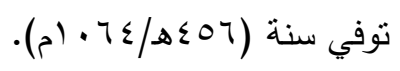

اقتبس مغلطاي منه نصاً واحداً(rوr) ، وذكره بلفظ " وابن حزم ينكرها " (rarr).

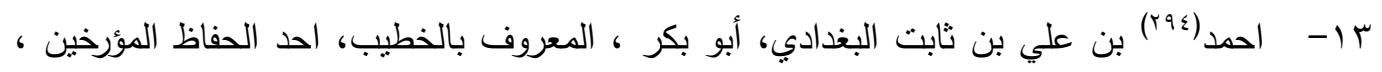
مولده في(غزية) رحل إلى مكة وسمع بالبصرة والدينور والكوفة وغيرها وعاد إلى بغداد من كتبه: " تاريخ

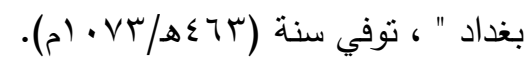

اقتبس مغلطاي منه نصاً واحداً( (90) ، ذكره بلفظ " والخطيب "(T94). 
العـــــــد الثاني والعشرون

ع ا- علي(rav) بن الحسن بن هبة اله ، أبو القاسم ، تقة الدين ابن عساكر الدمشقي، المؤرخ ، الحافظ

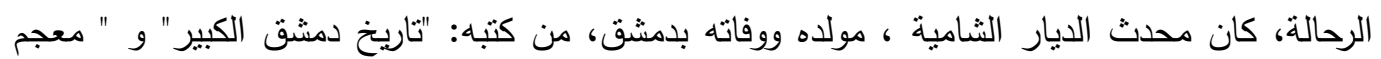

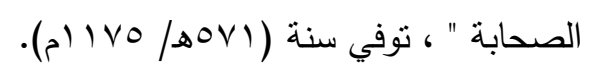

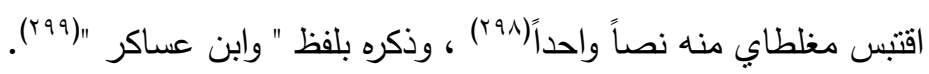

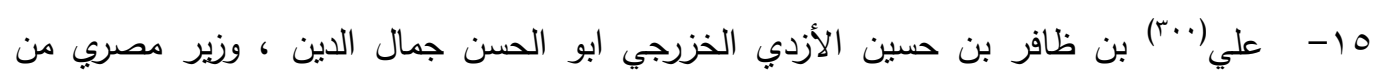

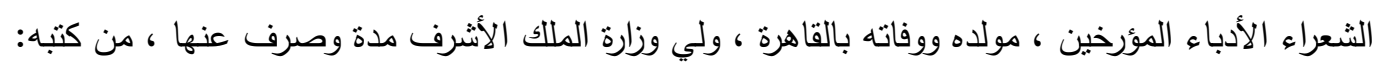

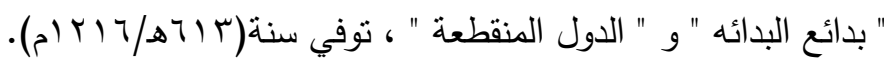

$$
\begin{aligned}
& \text { اقتنس مغلطاي منه نصاً واحداً (•r) ، ذكره بلفظ " قال الأزدي "(r+r) . }
\end{aligned}
$$

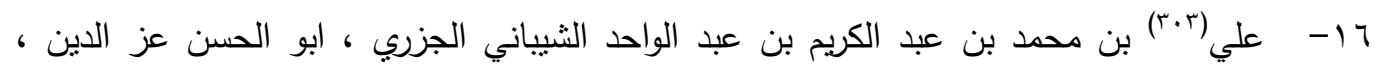

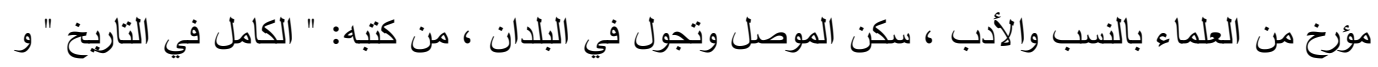

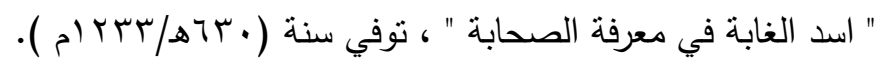

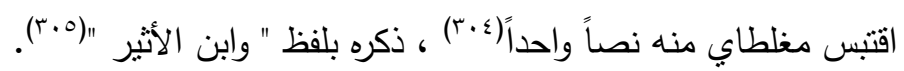

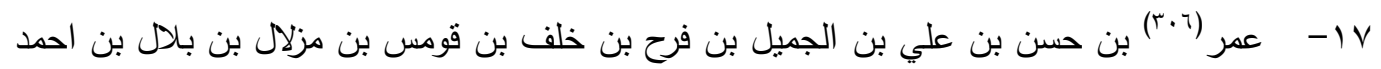

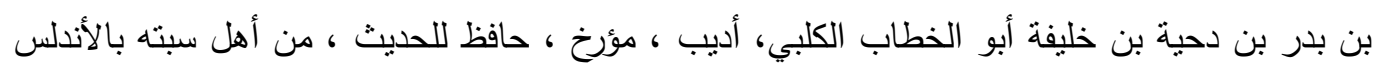

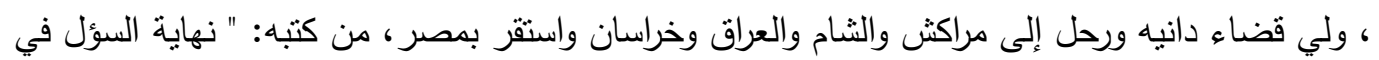

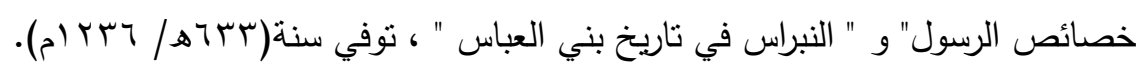

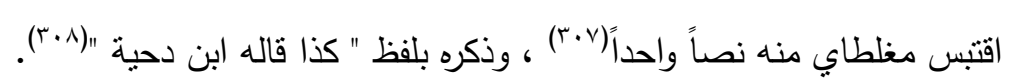

11- إبراهيم(9.9) بن عبد الله بن عبد المنعم بن أبي الدم الهمداني الحموي شهاب الدين ، أبو إسحاق

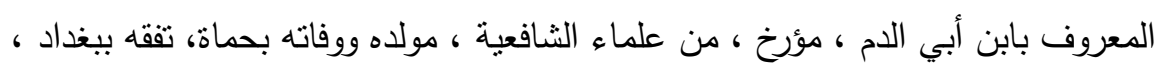
9 ا- وسمع بالقاهرة ، وتولى قضاء حماة ، من كتبه: " التاريخ المظفري " ، توفي

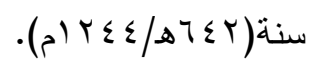


العـــــــد الثاني والعشرون

مجلــــة كليــــة التربيــــة

اقتبس مغلطاي منه نصاً واحداً(·"r) ، ذكره بلفظ " فيما حكاه المظفري "(1"(") .

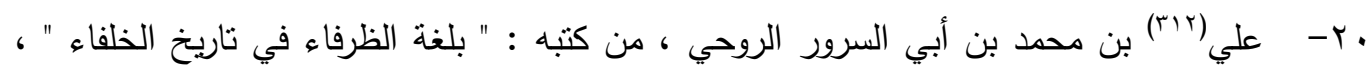

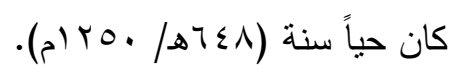

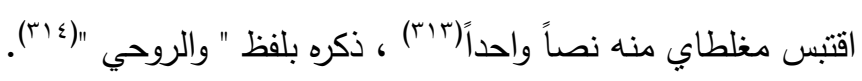

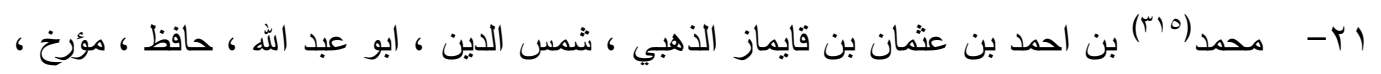

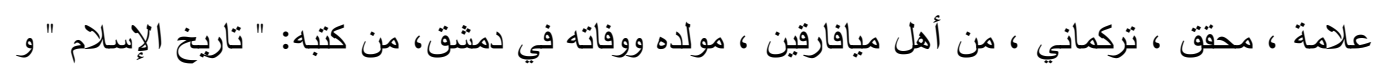

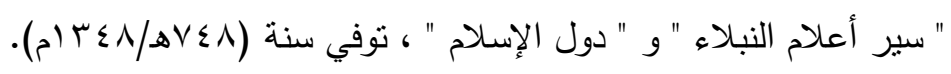

اقتبس مغلطاي منه نصاً واحداً (r) ، ذكره بلفظ " وقال الذهبي "(r)(r).

ثانيا : موارده من المجاهيل

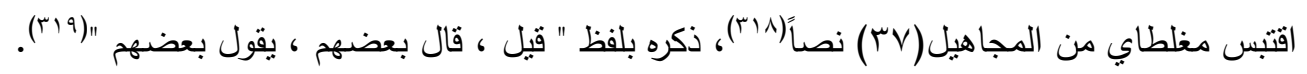
ثالثاً : موارده من الثعر

الثعراء الذين اخذ عنهم الحافظ مغلطاي الثعر مرتبة حسب ما وردت في كتاب " مختصر تاريخ الخلفاء " :

1- قال الثاعر : أخذ مغلطاي عنه الثعر في موضع واحد بييتين(·rr) قالها وهو يمدح الخليفة أبو

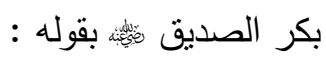

عنيق ما عنيق ذو المنظر الأنيق رشفت منه ريق كالزرنب الفتيق(rrا'. 
العـــــــد الثاني والعشرون

مجلــــة كليــــة التربيــــة

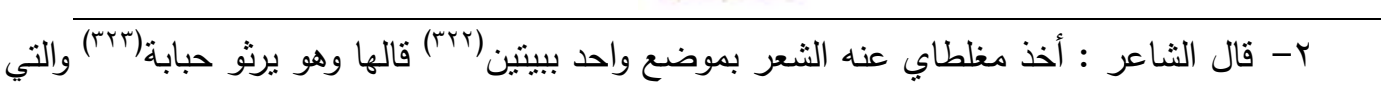

توفي بعدها عشقاً ، إذ يقول حين توفيت متمثلاً:

فان تسل عنك النفس أو تدع الهوى فالبأس تسلو عنك لا بالتـــــلد

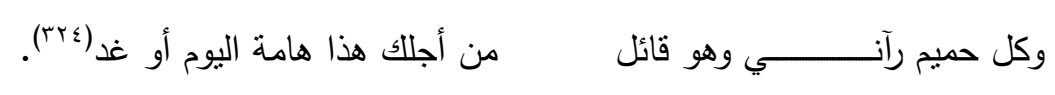

r- يقول بعضهم : أخذ مغلطاي عنه الشعر في موضع واحد ببيت واحد(roo) يقول فيه:

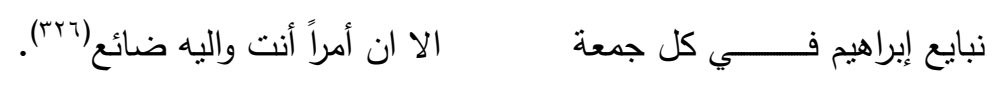

ع- هارون الرشيد: أخذ عنه الثعر في موضع واحد بثلاث أبيات(rrV) ذكرها عند نرجمته للخليفة

هارون الرشيد يقول فيها:

$$
\text { مالك الثلاث الآنسات عنانسي }
$$

0- الراضي : أخذ مغلطاي عنه في موضع واحد ثلاث أبيات(جrr) قالها وهو يترجم للخليفة الراضي ، إذ يقول:

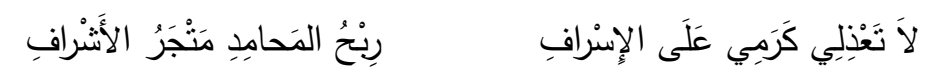

أَجْرِي كَآبائي الخَلأَيَفِ سَابِقاً

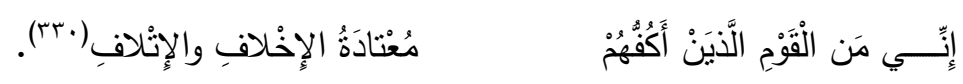


العــــــدد الثاني والعشرون

\section{مجلــــة كليــــة التربيــــة}

ج- قال الثاعر: أخذ مغلطاي عنه الثعر بموضع واحد بستة أبيات قالها وهو يترجم لـ(هولاكو) ، إذ يقول:

\begin{tabular}{|c|c|}
\hline لبكى عليهم الاعلــــى اياد & فلو كان شاهداً الأسود بن بعفر \\
\hline تركوا منازلـــــهم بغير معاد & ماذا أومل بعد آل المصطفــى \\
\hline والكـــــرخ والأنبار والاجماد & أهــل الرصافة والعراق وواسط \\
\hline مـن قاطن أو رائح أو غاد & ملكوا البلاد ومسـن عليها عنوة \\
\hline فكأنما كانوا علـــــى ميعاد & رت الرياح على محل بلادهم \\
\hline بوماً بصر الـ بلا أو نكاد & كـى بـه \\
\hline
\end{tabular}


بعد هذه الدراسة المنواضعة لمنهج وموارد الحافظ مغلطاي في كتابه " مختصر ناريخ الخلفاء " نستطيع أن نسجل أبرز وأهم النتائج التي توصلنا إليها:

1- عاش الحافظ مغلطاي في عصر المماليك البحرية والذي تميز بعدم الاسنقرار واضطراب معظم

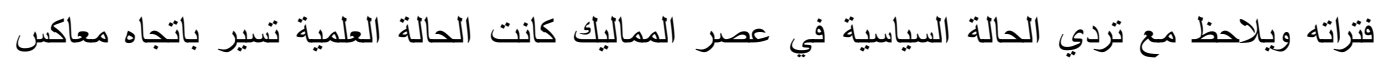

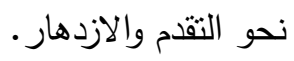

r- في هذه الفترة المضطربة ظهر مغلطاي بن قليج بن عبد الله أبو عبد الله علاء الدين الحكري

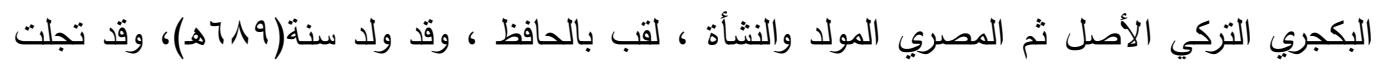

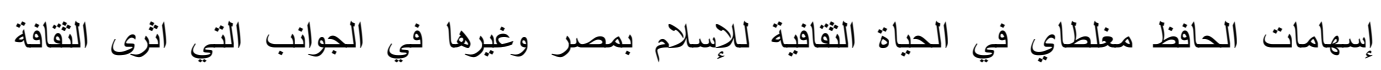
الإسلامية لعلماء مصر وقتئذ ، إذ سمع منه كبار العلماء فتخرج على يديه كثرة من الثيوخ والأقران .

r- قام الحافظ مغلطاي برحلات دراسية إلى البلاد المصرية والثامية ، وانكب على دراسة الحديث

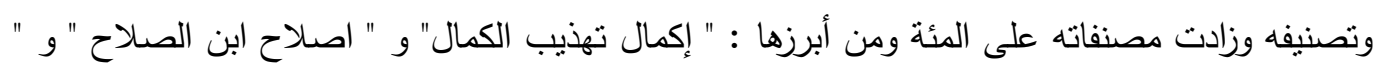

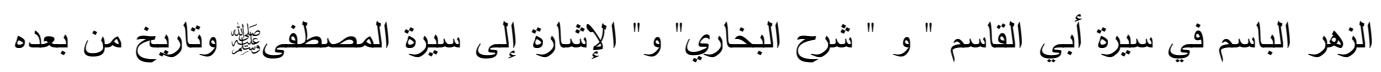

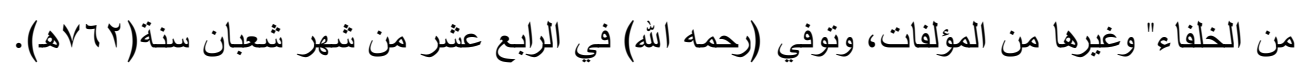

ع - توصلت الدراسة إلى أثبات حقيقة ان الكتاب موضوع الدراسة مهم ويُعد من الكتب التي نتاولت

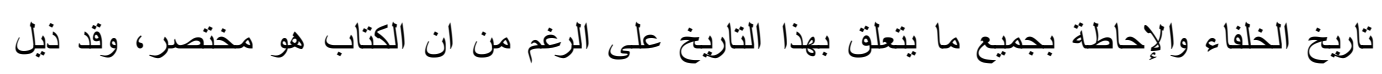

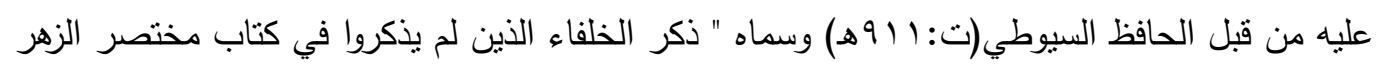
الباسم في سيرة أبي القاسم ".

0- انسم كتاب " مختصر تاريخ الخلفاء " بكثرة موارده ، إذ ان الحافظ مغلطاي كان يتمتع بقدرة كبيرة

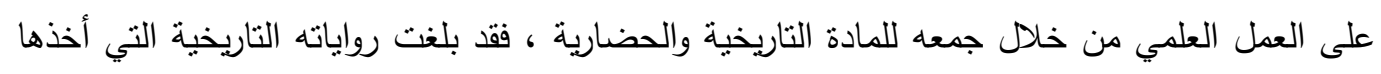
عن المؤلفين بلغت(1) رواية).وكان الحافظ مغلطاي ينشد الحقيقة من خلال إيراده للرواية الواحدة.

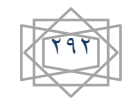


العـــــــد الثاني والعشرون

\section{مجلـــة كليــــة التربيـــة}

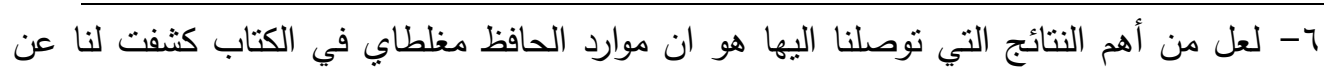

الكتب المخطوطة والمفقودة والتي أرخت لتاريخ الخلفاء ، ولولا نقوله منها ، لبقينا نجهلها حتى يومنا هذا.

، أمتاز منهج الحافظ مغلطاي بالوضوح والأمانة العلمية من خلال ذكره للمصادر التي اعتمد عليها

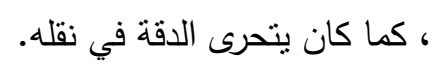

^- توصلت الدراسة أيضاً إلى ان الحافظ مغلطاي كان له منهجاً متميزاً في استخدامه للموارد ، إذ انه وضع في ذلك معايير خاصة في تفضيلها واختيارها ، كما كان له منهجه في النقل والاقتباس منها.

9- ومن خلا هذه الدراسة اتضح ان الحافظ مغلطاب كان بعتمد المصادر الأصلية في كتابه ولاسيما تلك التي تتعلق بتاريخ الخلفاء. 


\section{العــــــد الثاني والعشرون}

\section{مجلــــة كليــــة التربيـــة}

\section{قائمة المصادر والمراجع}

أولاً : المصادر الأولية :

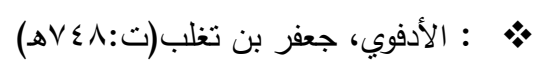

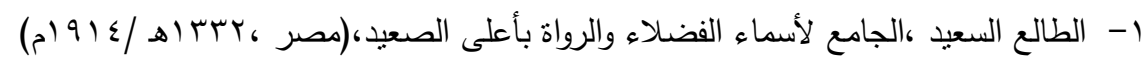

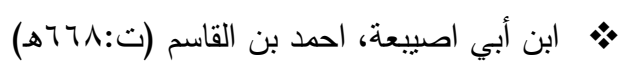

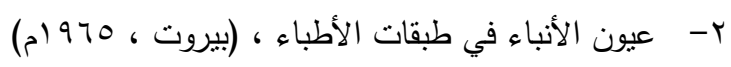

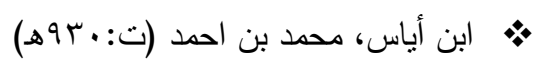

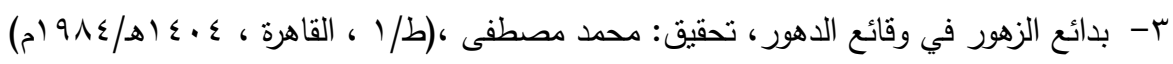

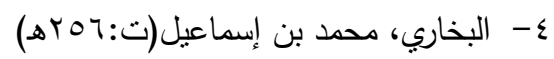

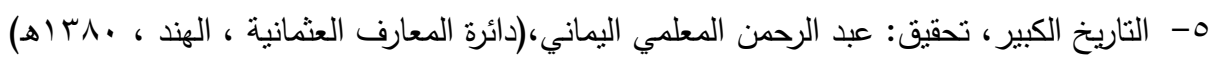

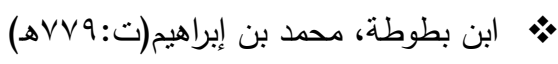

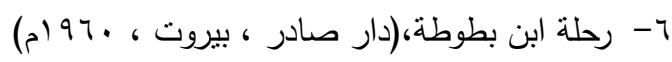

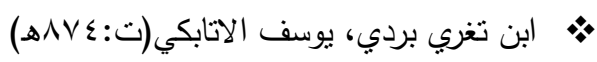

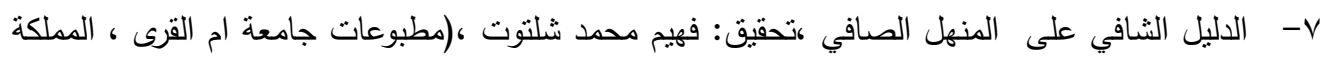

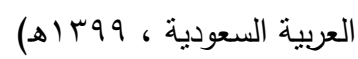

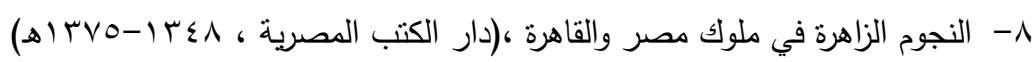

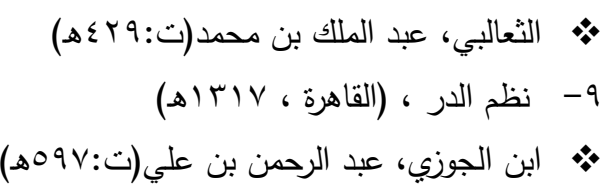

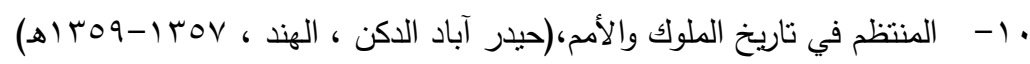

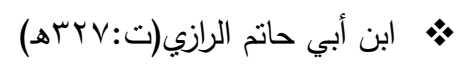

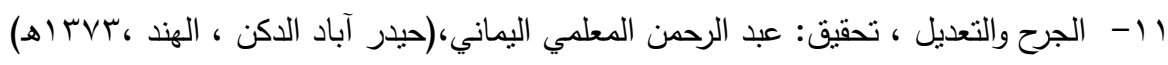

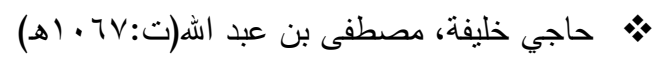

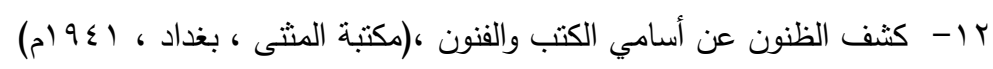

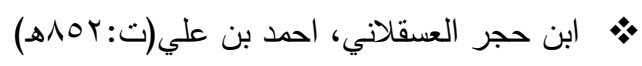

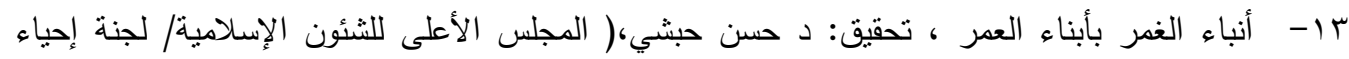

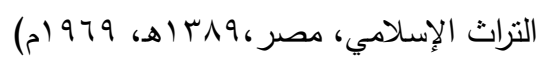


ـ ا - تعجيل المنفعة بزوائد رجال الأئمة الأربعة ، تحقيق: د.اكرام اله امداد الحق، (ط// ، دار البشائر، بيروت

$$
\text { (م) } 997 \text { ، }
$$

1 - الدرر الكامنة في أعيان المئة الثامنة، مراقبة: محمد عبد المعيد خان،(ط/r/حيدر اباد الدكن ، الهند ،

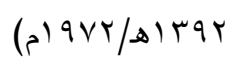

1ا- - راهع الأصر عن قضاة مصر ،تحقيق: د. علي محمد عمر،(ط/(ا، مكتبة الخانجي، القاهرة ،

$$
\text { (م) } 991 / ه) \leq 11
$$

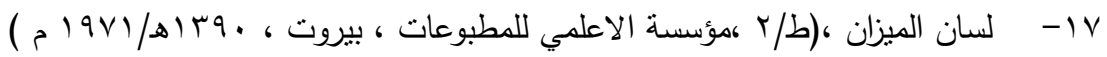

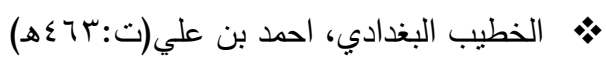

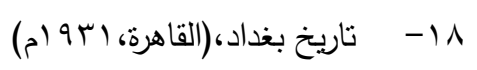

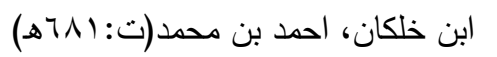

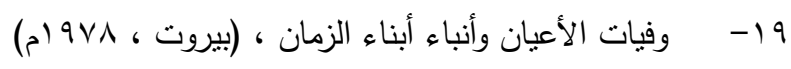

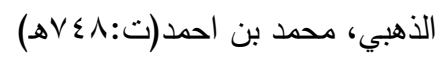

• ץ- سير أعلام النبلاء، تحقيق: مجموعة من المحققين بإثراف الشيخ شعيب الأرناؤوط، (ط/r ، مؤسسة

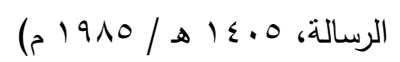

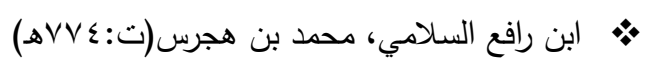

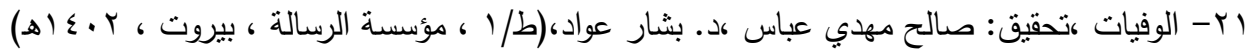

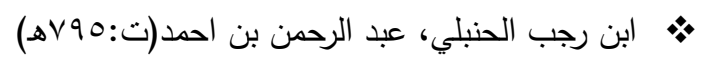

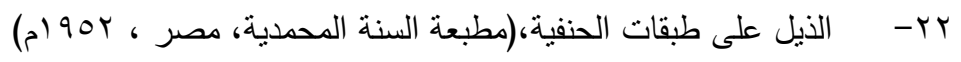

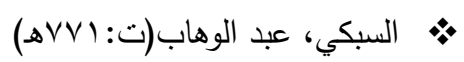

r ب- طبقات الثافعية الكبرى، تحقيق: د. محمود محمد الطناحي د. عبد الفتاح محمد الحلو،(ط/r ، هجر

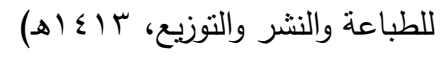

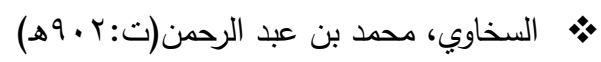

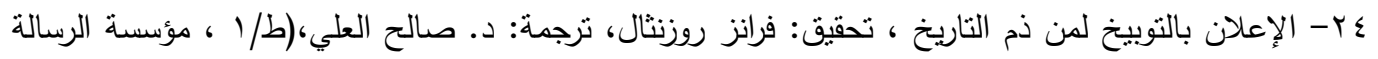

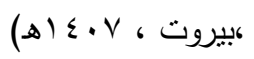

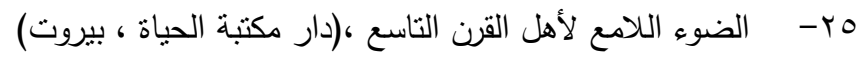

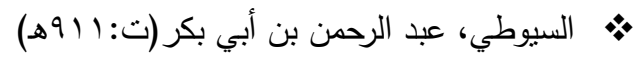

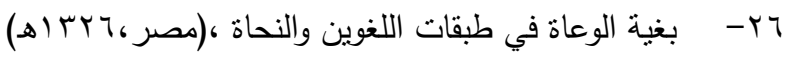

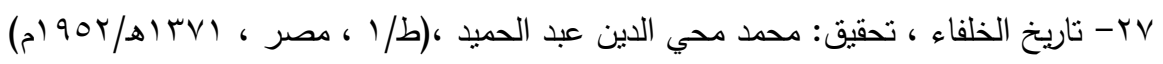


1ץ- حسن المحاضرة في تاريخ مصر والقاهرة ،تحقيق: محمد أبو الفضل إبراهيم،(ط// ،دار إحياء الكتب العربية

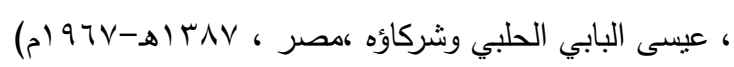

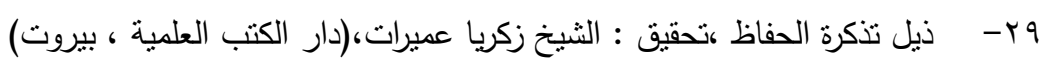

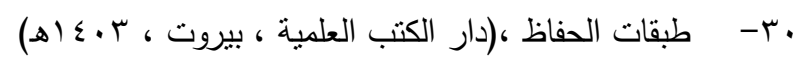

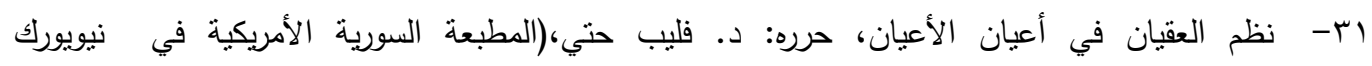

(م) $9 \vee Y / ه) T \leq 76$

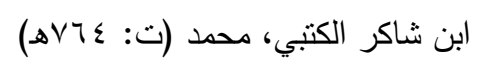

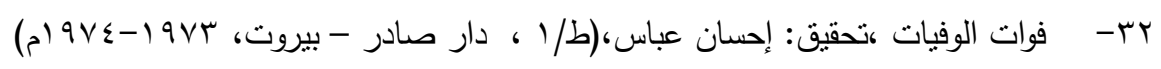

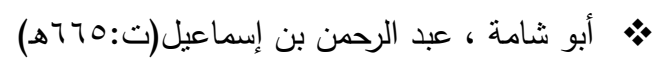

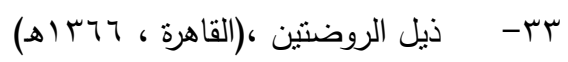

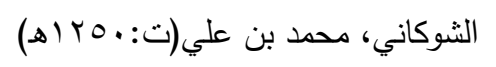

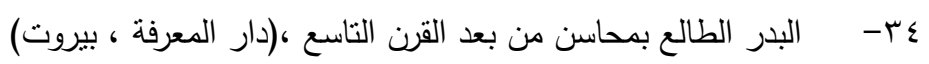

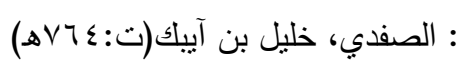

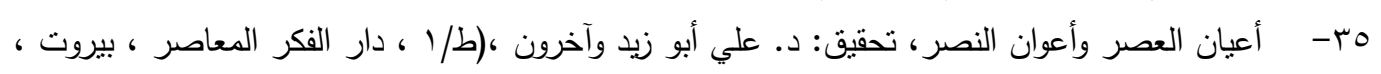

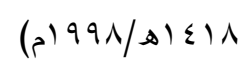

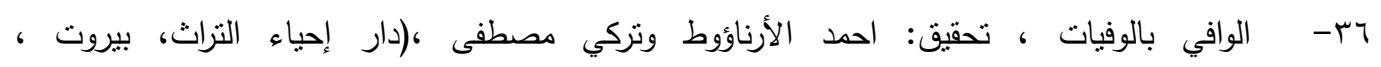

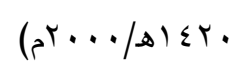

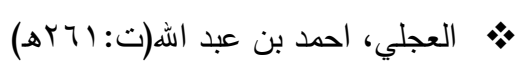

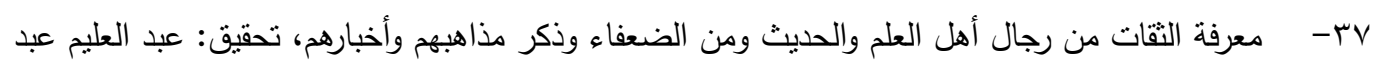

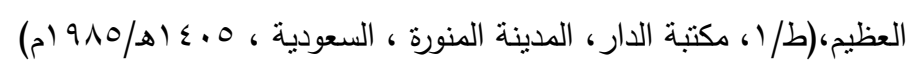

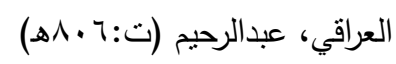

^ץ- - شرح (التبصرة والتذكرة =الفية العراقي)،تحقيق: عبد اللطيف الهميم، ماهر ياسين فحل،(دار الكتب

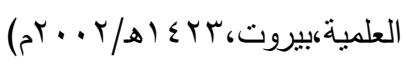

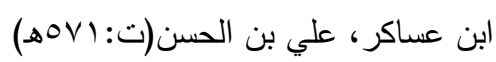

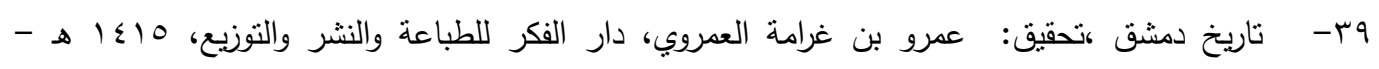

(c) 1990

ابن العماد الحنبلي، عبد الحي(ت:19 مـ • (هـ)

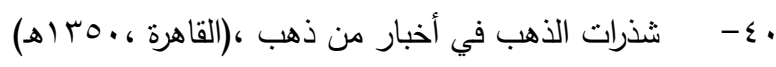




\section{العـــــــد الثاني والعشرون \\ مجلــــة كليــــة التربيـــة

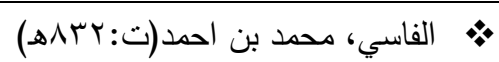

اء- ذيل التقييد في رواة السنن والأسانيد ، تحقيق: كمال يوسف الحوت ، (ط/ ، ، دار الكتب العلمية ،

$$
\begin{aligned}
& \text { بيروت، · (1 أه//99 (م) }
\end{aligned}
$$

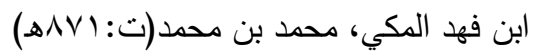

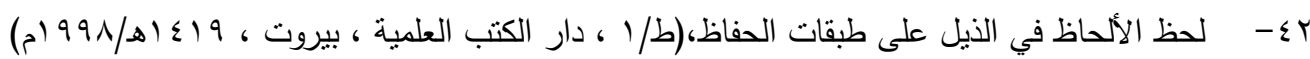

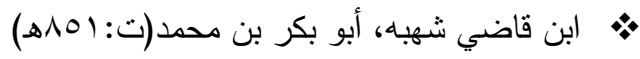

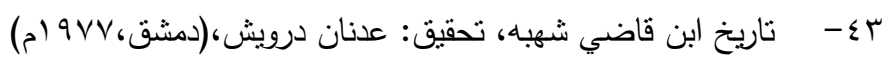

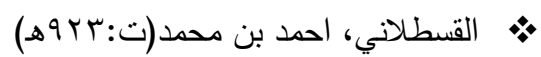

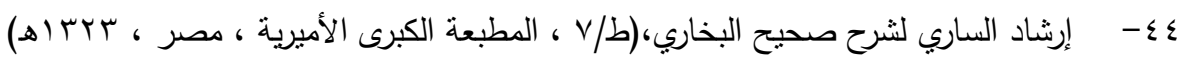

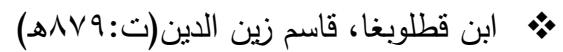

0ء- - تاج التراجم في طبقات الحنفية ،تحقيق: محمد خير رمضان يوسف ،(ط/ إن ، دار القلم ، دمشق

$$
\text { (م) } 994 / 8) \leq 1 r_{6}
$$

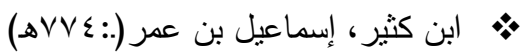

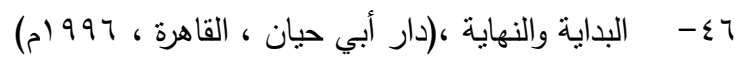

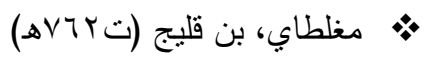

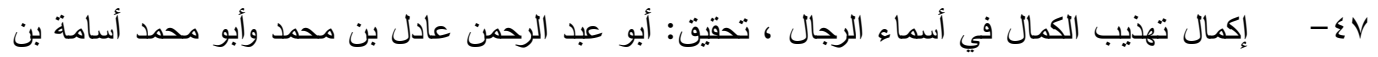

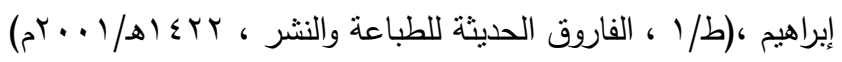

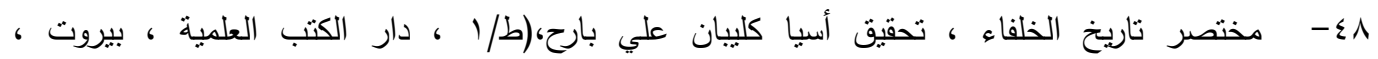

$$
(\text { ) }
$$

؟ - مختصر السيرة النبوية لمغلطاي ، تقديم وتحقيق وتعليق : د. محمد زينهم محمد عزب ، (دار المعارف ،

$$
\begin{aligned}
& \text { القاهرة ، كr } \\
& \text { المقري، احمد بن محمد(ت: إهـ ـ (هـ) }
\end{aligned}
$$

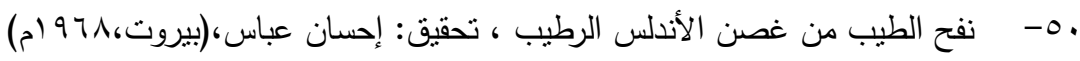

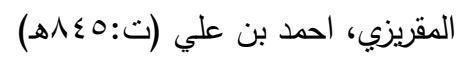

10- السلوك في معرفة دول الملوك ، تحقيق: محمد عبد القادر عطا ، (ط/ ، ، دار الكتب العلمية ، بيروت ،

$$
\text { (م) } 99 \mathrm{~V}
$$

(المواعظ والاعتبار بذكر الخطط والآثار ،(مكتبة المثثى، بغداد)

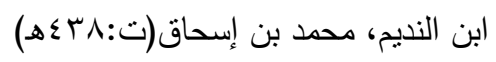




\section{العـــــــد الثاني والعشرون}

\section{(I)

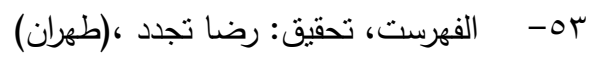

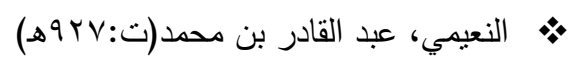

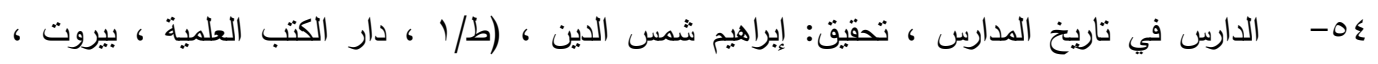

(م) $99 \cdot / 8) \leq 1$.

ابن الوردي، عمر بن المظفر (ت:

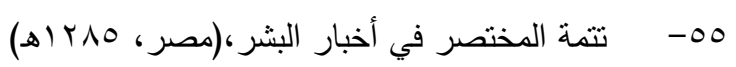

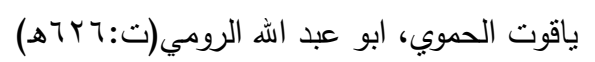

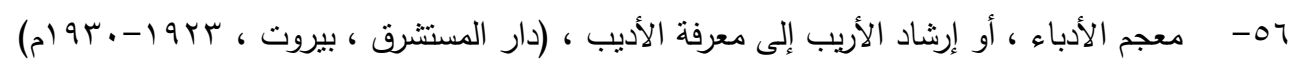

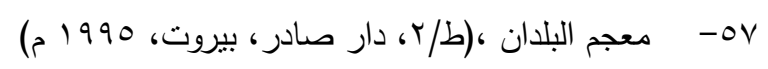

ثانياً: المراجع الحديثة :

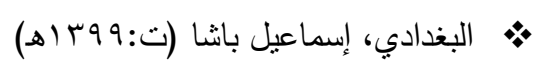

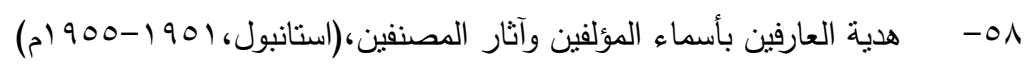

$$
\begin{aligned}
& \text { تيمور، احمد }
\end{aligned}
$$

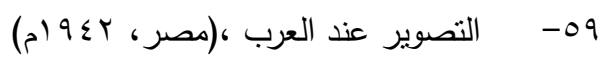

$$
\begin{aligned}
& \text { حمزة ، عبد اللطيف }
\end{aligned}
$$

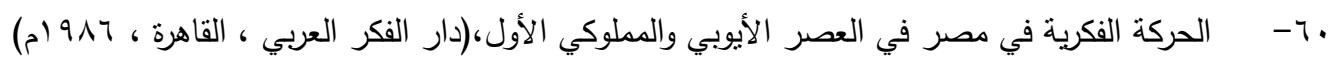
خليفة ، محمد رشاد

آ- مدرسة الحديث في مصر ،(الهيئة العامة لثؤون المطابع في القاهرة)

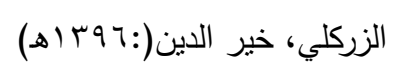

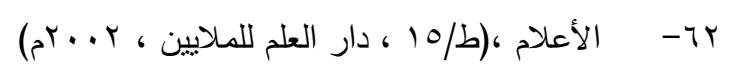

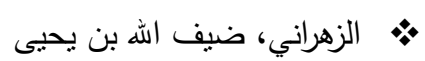

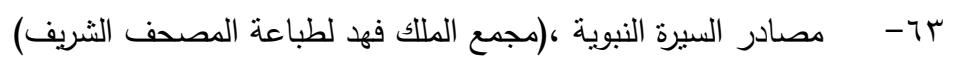

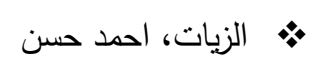

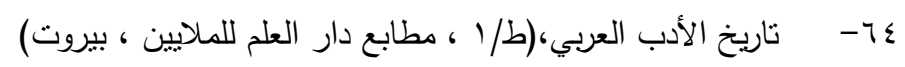

سركيس، يوسف بن اليان

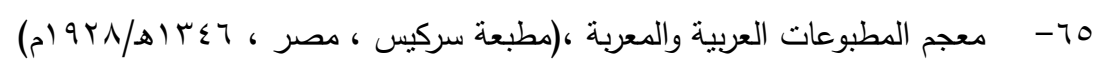

سرور ، دم: دمال الدين

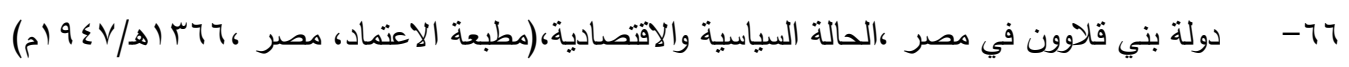


* * مليم ، محمود رزق

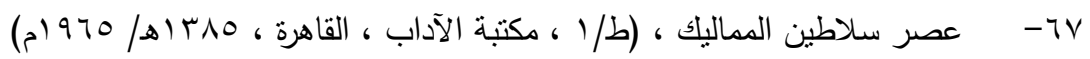

* م الشكعة ، د. مصطفى

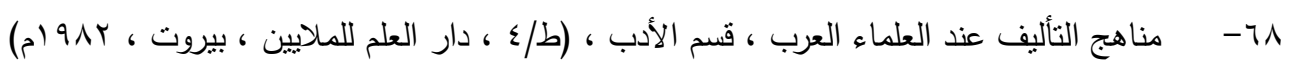

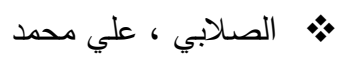

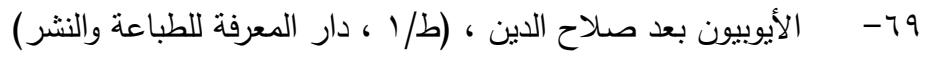

طقوش ، محمد سهيل

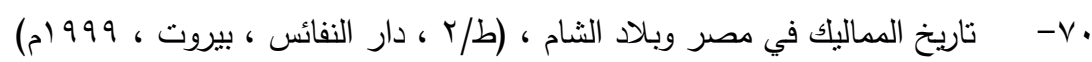

$$
\text { عاشور ، سعيد عبد الفتاح }
$$

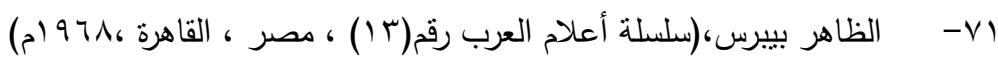

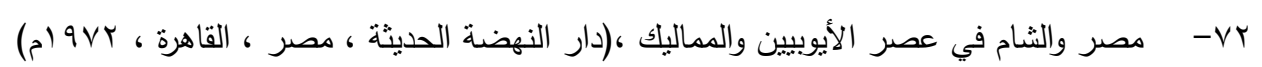

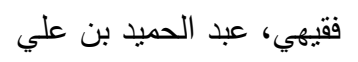

rV- - مهود العلماء المسلمين في تصنيف السيرة النبوية في القرنين الثنامن والتاسع الهجريين ، (مجمع الملك

فهر لطباعة المصحف الشريف بالمدينة المنورة )

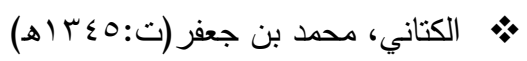

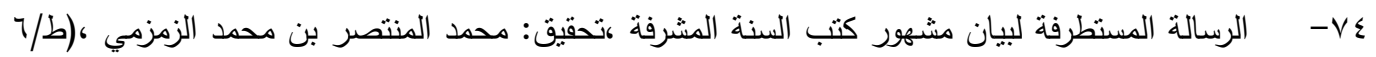

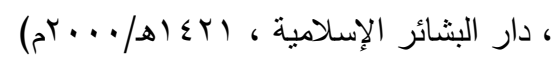

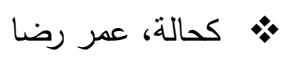

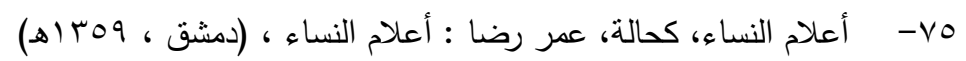

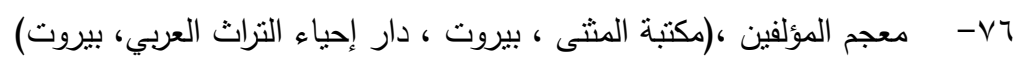


تعني كلمة مملوك ما يقصد نربيته والاستعانة به كجند وحكام ، على عكس لفظ (العبيد) التي تعني العبودية ، فالعبد

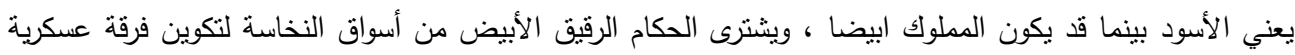

خاصة .

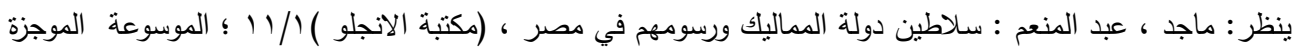

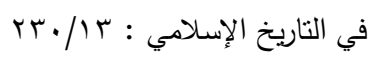

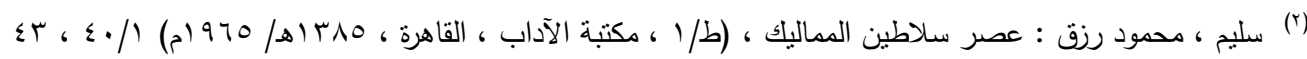

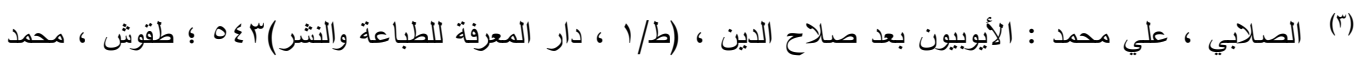

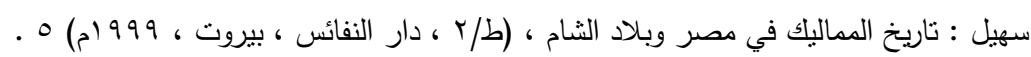

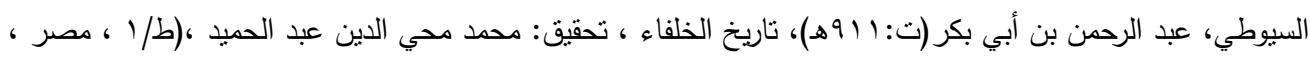

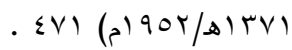

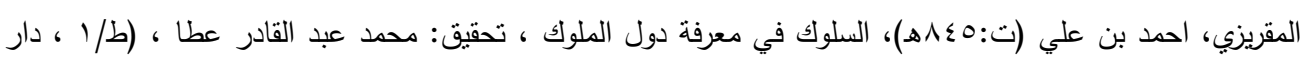

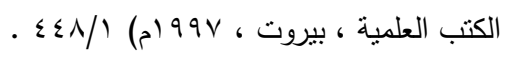

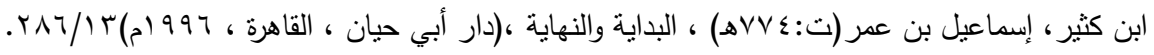

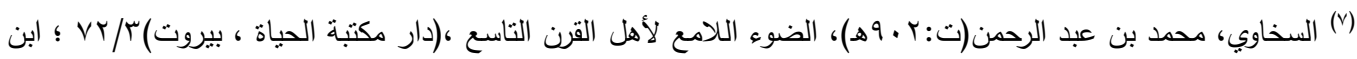

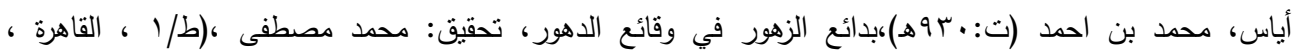

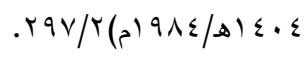

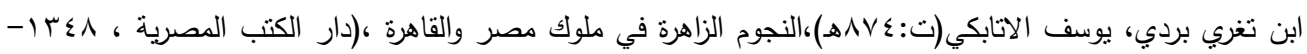

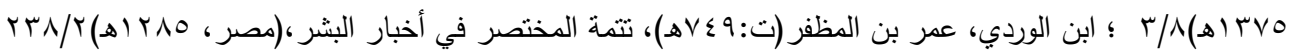

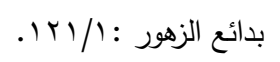

المقريزي : السلوك لمعرفة دول الملوك : القسمان الأول والثاني من الجزء الثاني.

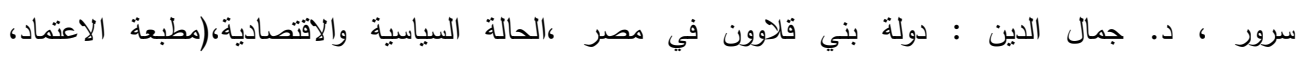

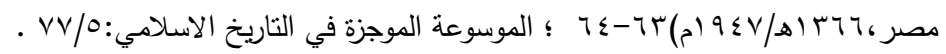

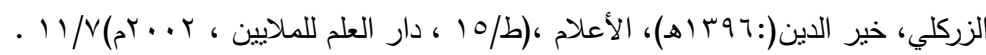

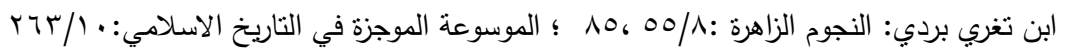

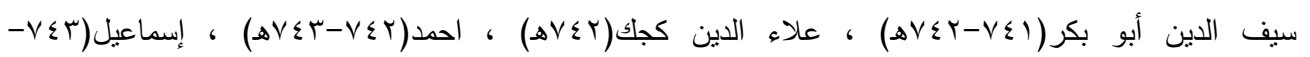

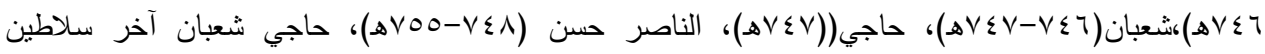

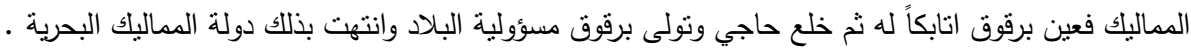

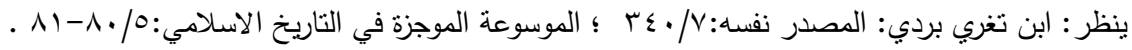

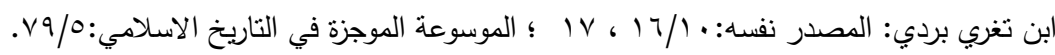




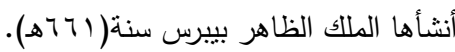

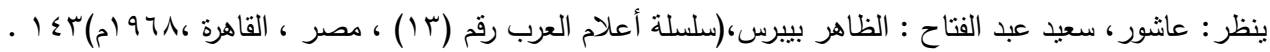

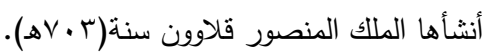

ينظر : حمزة ، عبد اللطيف: الحركة الفكرية في مصر في العصر الأبوبي والمملوكي الأول،(دار الفكر العربي ، القاهرة

$$
107 \text { (م) } 1917 \text { ، }
$$

وهي المدرسة التي ابتدأها العادل كتبغا واتمها الملك الناصر محمد بن قلاوون سنة(ب • هـ).

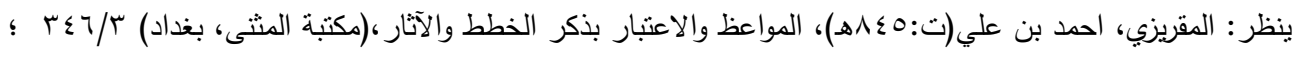

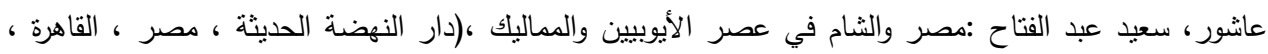

$$
\text { - 19r) 19Vr }
$$

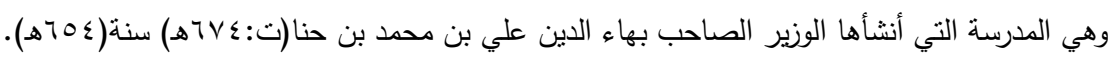

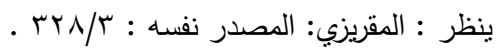

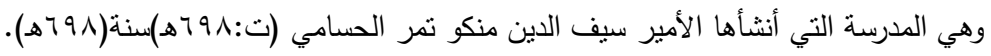

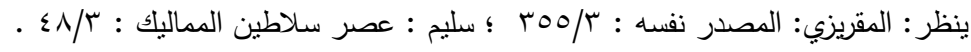

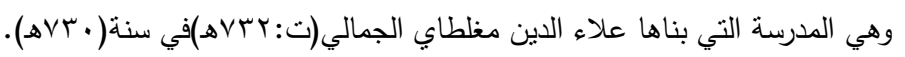

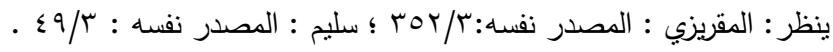

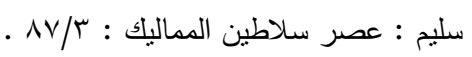

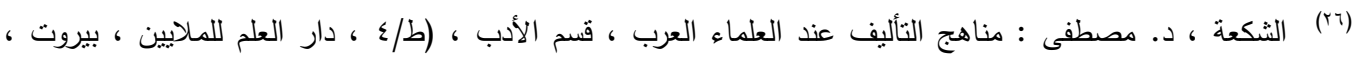

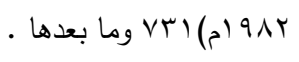

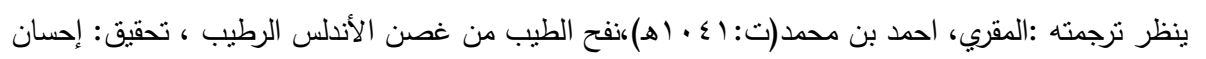

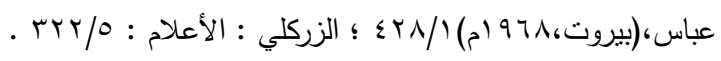

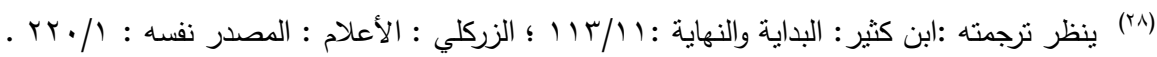

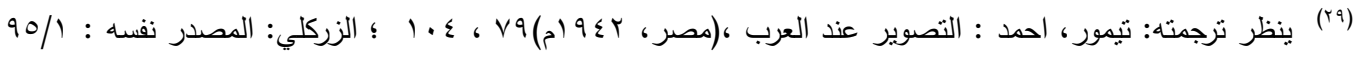

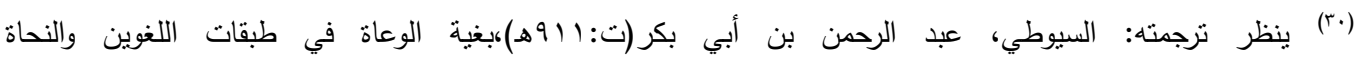

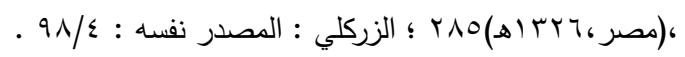

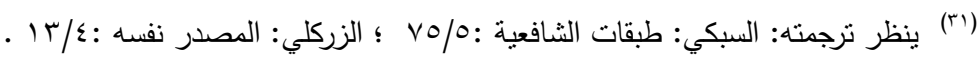

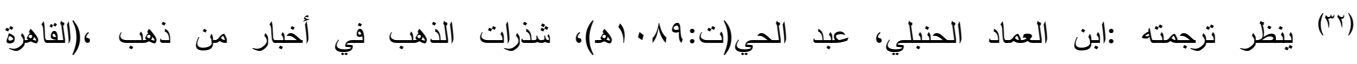

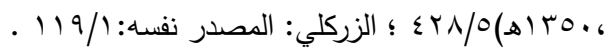




\section{العــــــــد الثاني والعشرون}

\section{مجلــــة كليــــة التربيــــة}

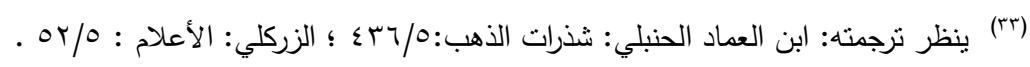

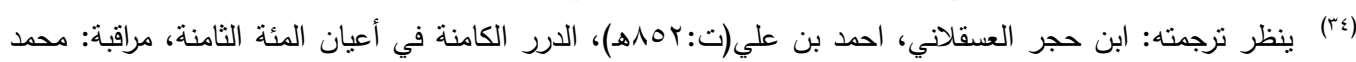

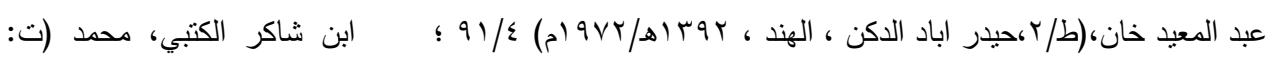

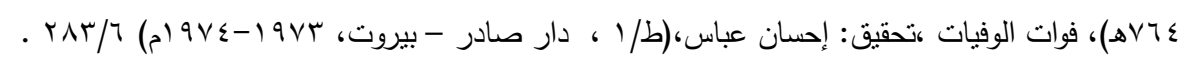

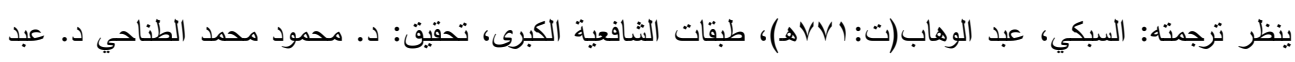

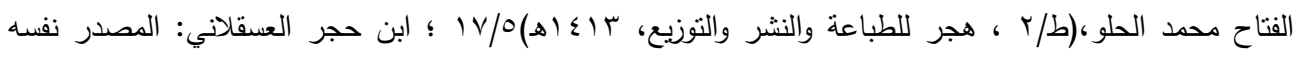
. $r \wedge \varepsilon / 1$ :

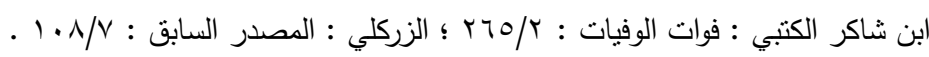

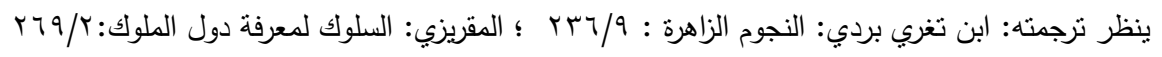

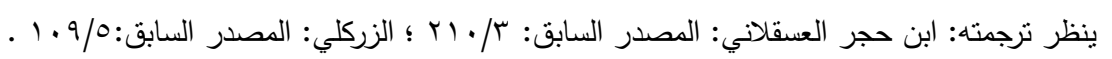

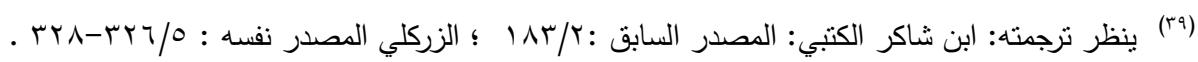

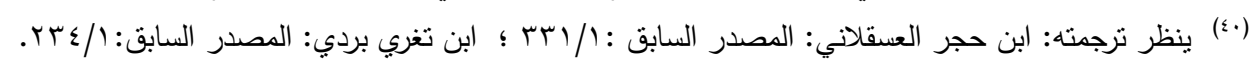

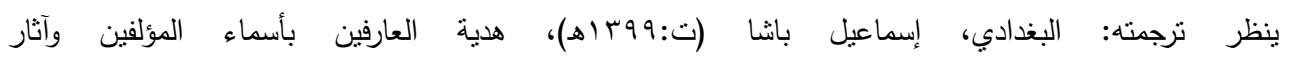

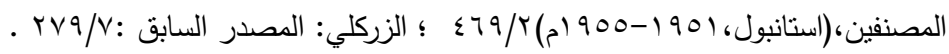

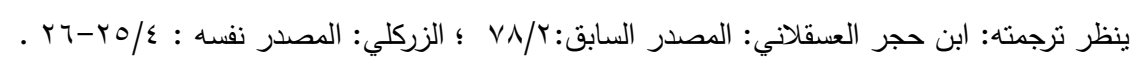

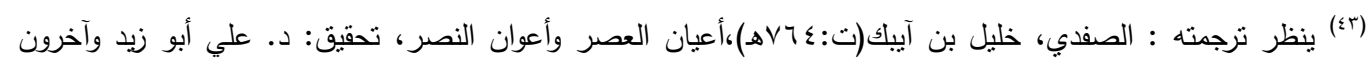

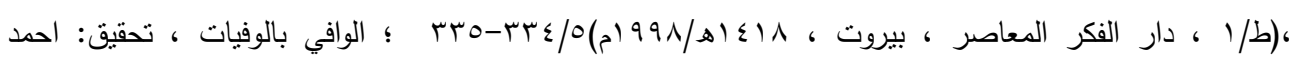

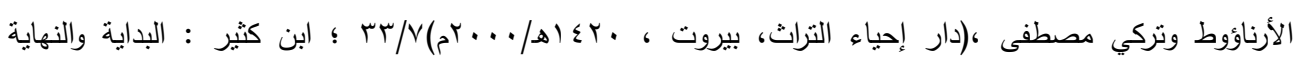

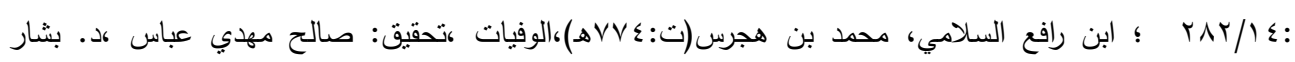

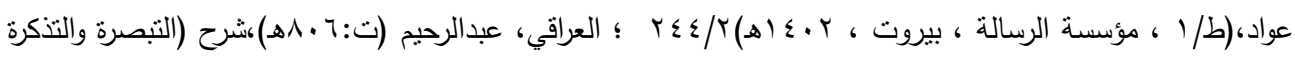

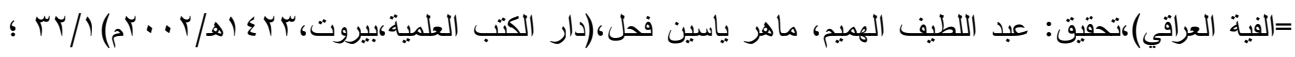

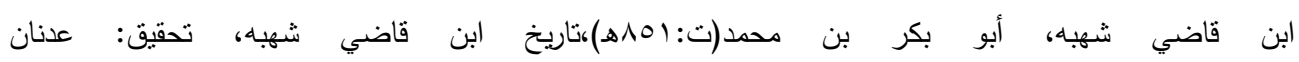

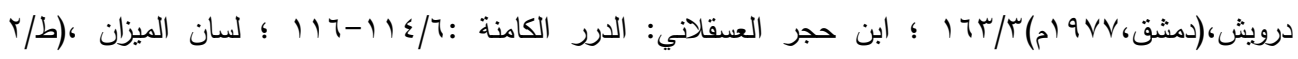

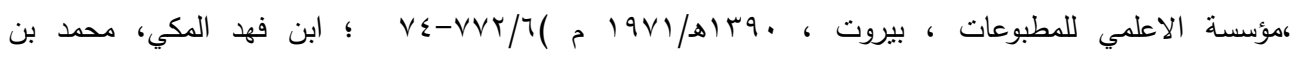

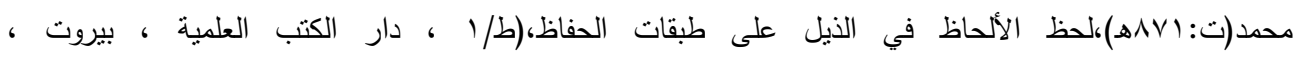

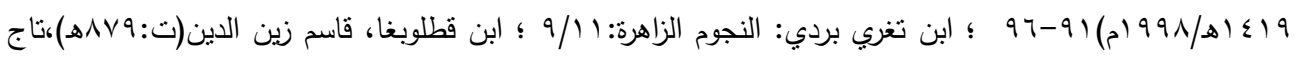

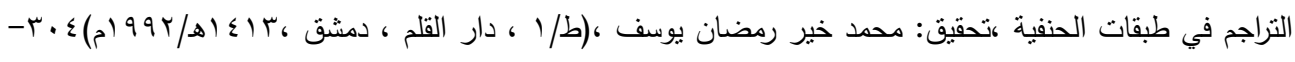

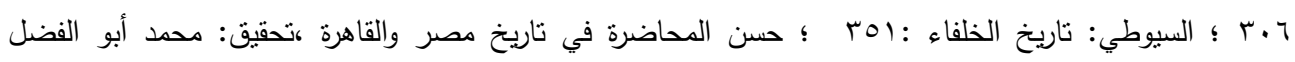

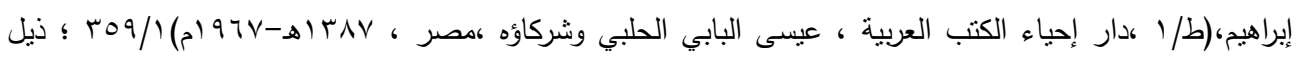

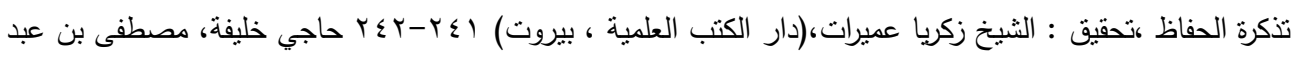

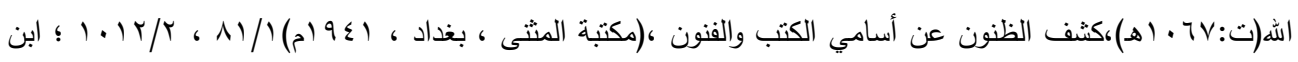




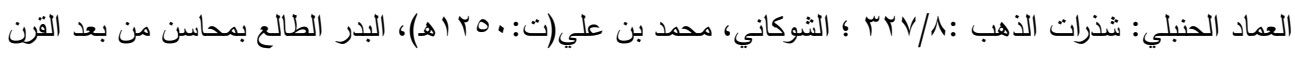

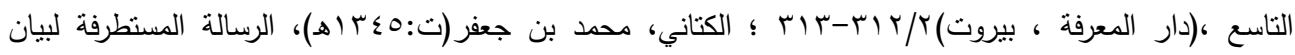

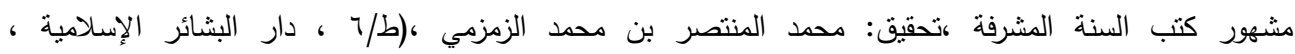

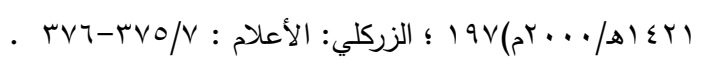

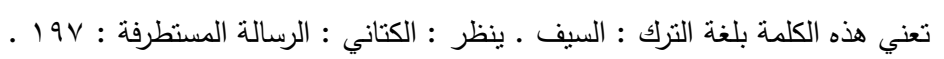
بفتح الباء وسكون الكاف وفتح الجيم ، نسبة الى جامع البكجري وهذا الجامع بحكر البكجري قريباً من الدكة. $(\varepsilon 0)$

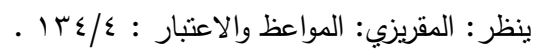

مغلطاي: كلمة تركية مركبة من كلمتين(مغل)وتعني جيل من الناس ، و (طاي) وتعني الفرخ او المهر ، فيكون المعنى المنى $(\Sigma \top)$ ولد الجيل من الناس.

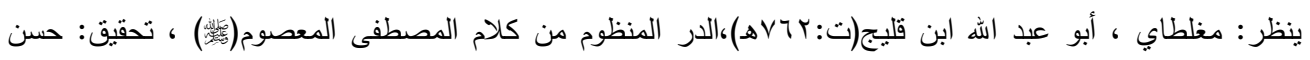

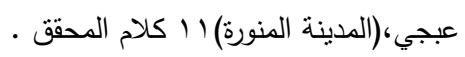

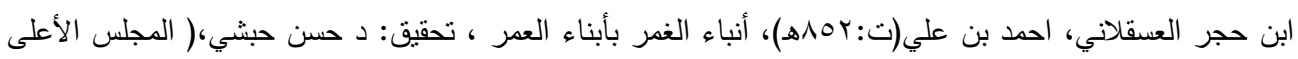
$(\varepsilon v)$

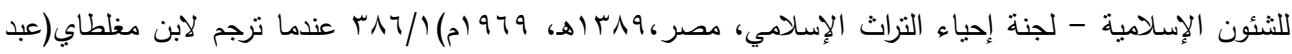

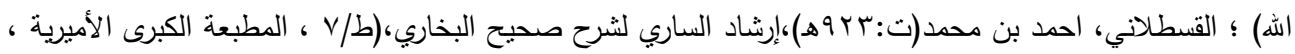

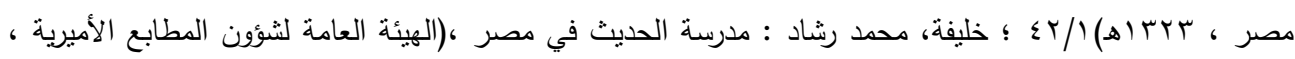

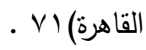

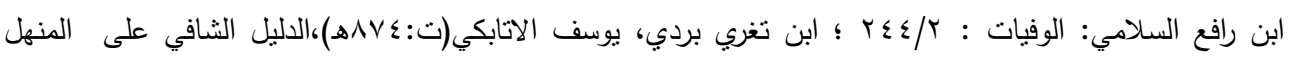

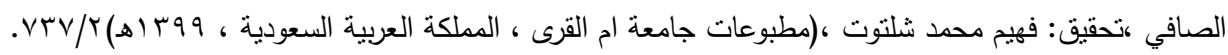

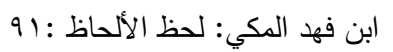

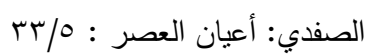

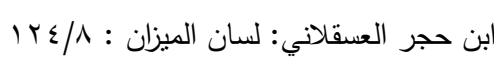

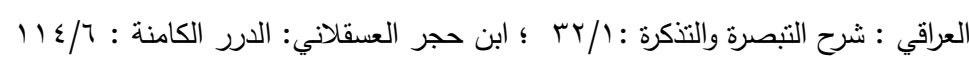

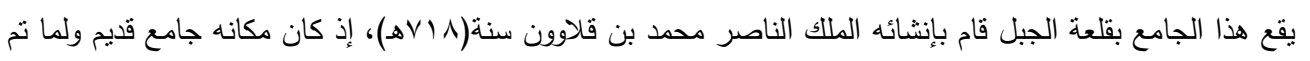
(or)

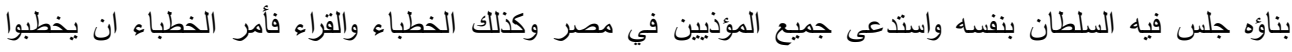
والمؤذنين ان يأذنون ، فوقع اختياره على خطيب جامع عمرو بن العاص وجعله خطياً بهذا الجامع ، وقام با ختيار

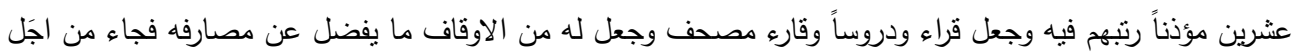

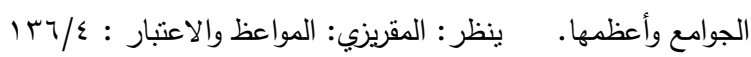
ابن تغري بردي، الدليل الثافي:

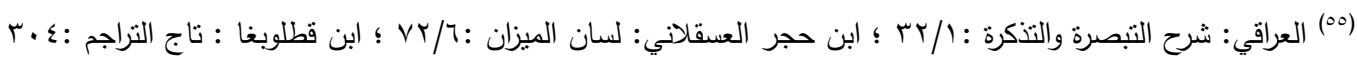

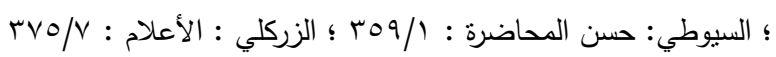

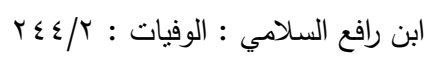




\section{العـــــــد الثاني والعشرون}

\section{مجلـــة كليــــة التربيـــة}

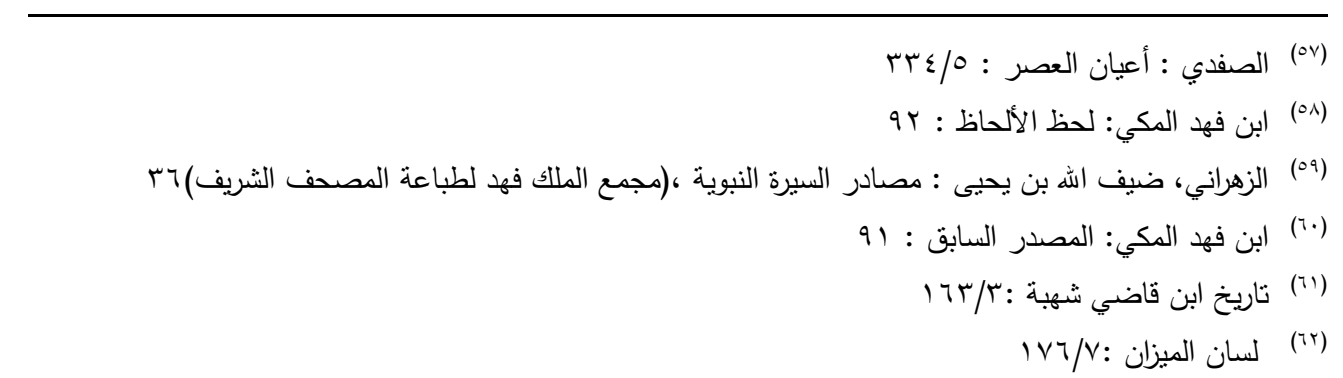

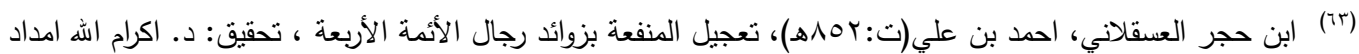

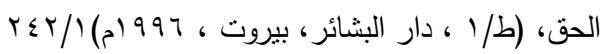

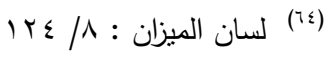

$$
\begin{aligned}
& \text { 9/11 : النجوم الزاهرة }
\end{aligned}
$$

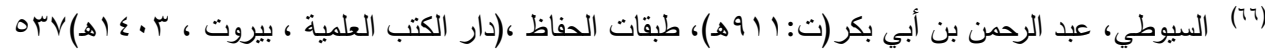

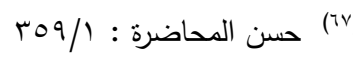

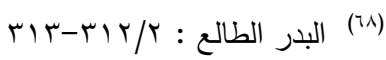

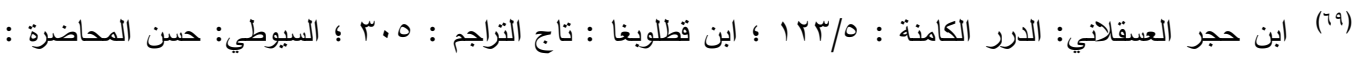

$$
\begin{aligned}
& \text { ro9/1 }
\end{aligned}
$$

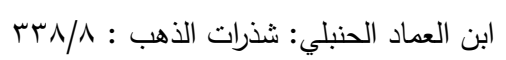

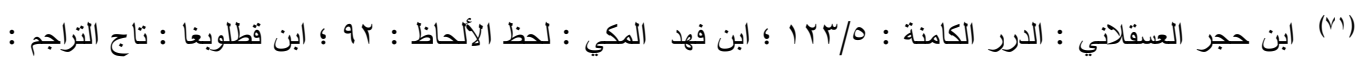

$$
\text { r.o }
$$

$$
\begin{aligned}
& \text { المقريزي : (Vr) } \\
& \text { (Vr) }
\end{aligned}
$$

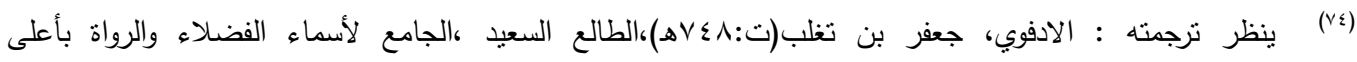

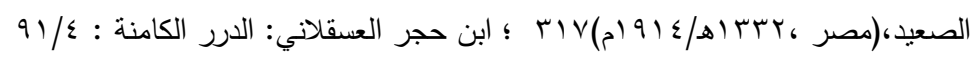

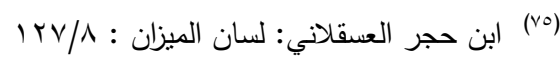

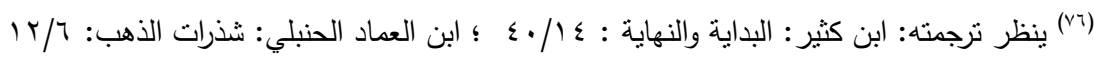

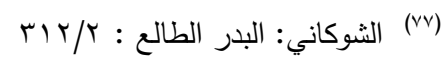

(r/)

$$
91 \text { : (199) }
$$

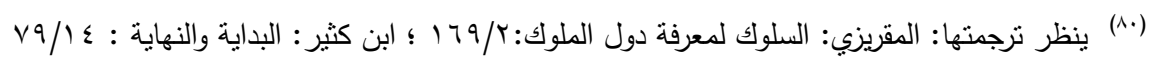

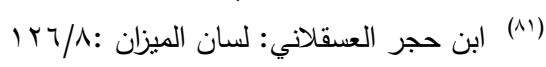

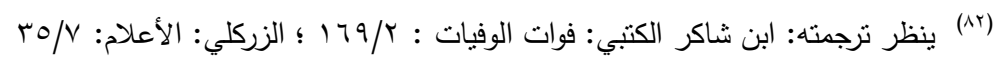

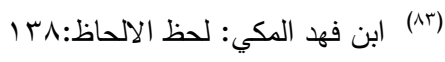




\section{العـــــــد الثاني والعشرون}

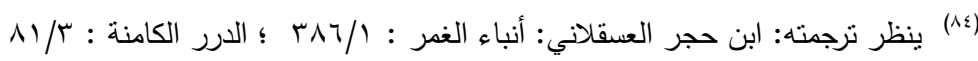

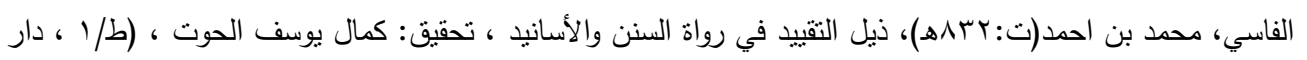

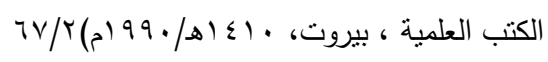

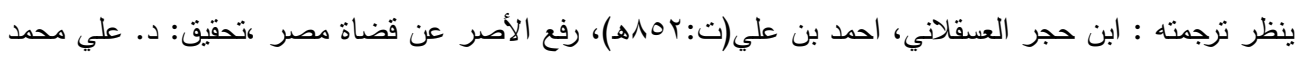

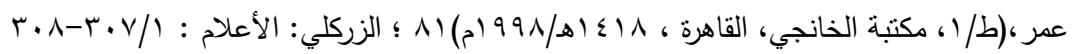

$$
\begin{aligned}
& \text { rAT/r : الضوء اللادع (Av) }
\end{aligned}
$$

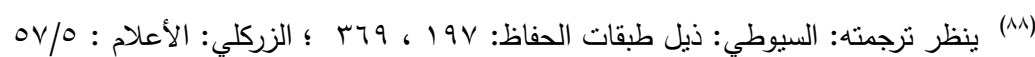

$$
\text { (^a) }
$$

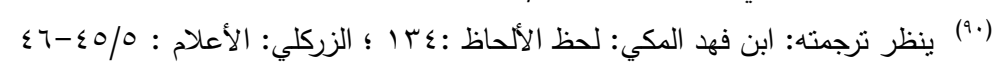

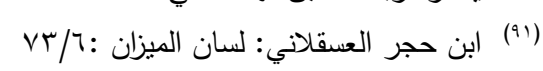

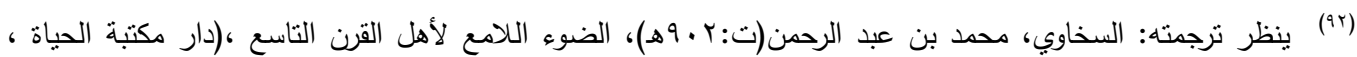

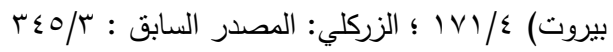

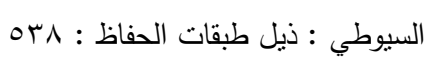

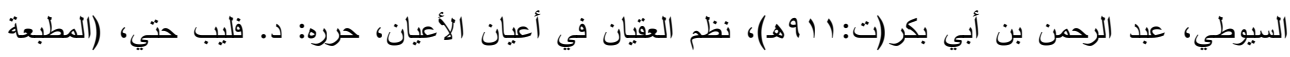

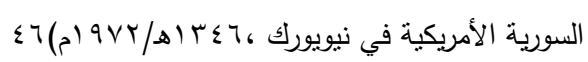

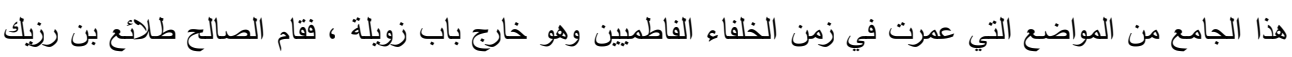

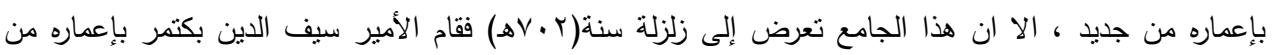

$$
\begin{aligned}
& \text { جديد. }
\end{aligned}
$$

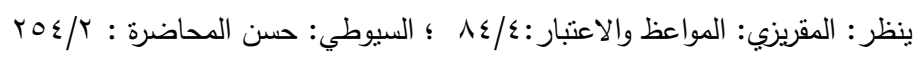

$$
\begin{aligned}
& \text { تقدمت ترجمته ضمن مبحث مولد الحافظ مغلطاي. }
\end{aligned}
$$

يقع هذا الجامع بالقرب من قلعة الجبل فيما بين باب الوزير والتبانة وكان قبل ذلك موضعاً لمقابر أهل القاهرة ، ثم قام

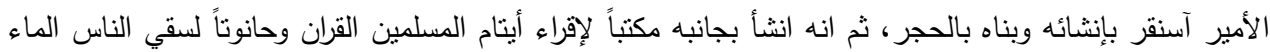

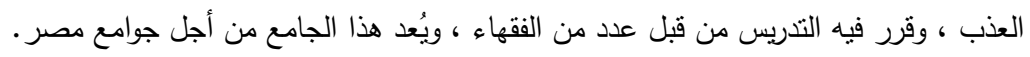

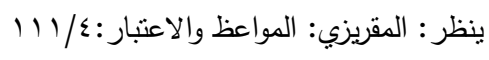

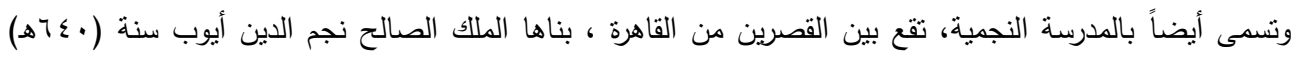

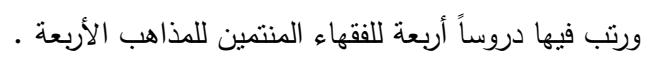

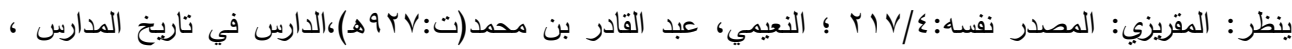

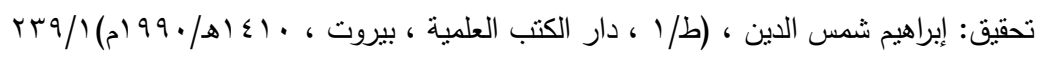

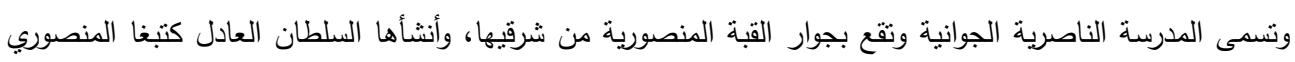

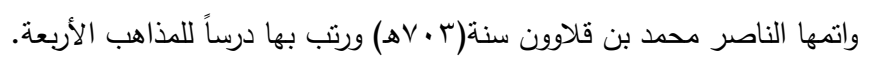

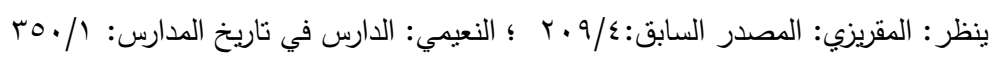

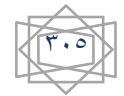


تقع هذه المدرسة خارج باب زويلة من خط حارة حلب ، بناها الحكيم مهذب الدين المعروف بابن حليقة رئيس الأطباء ،

$$
\text { نولى فيها مغلطاي مشيخة الحديث ، فضلاً عن التدريس بها. }
$$

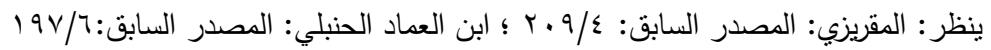

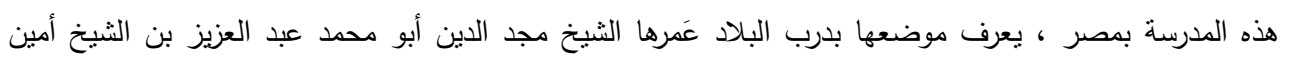

$$
\begin{aligned}
& \text { الداري سنة(r7 } 7 \text { هـ) وقرر فيها مدرساً ومعيدين وإماماً ومؤذناً وعشرين طالباً. }
\end{aligned}
$$

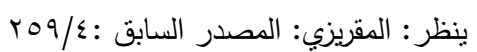

تقع هذه المدرسة خارج القاهرة بجوار جامع الأمير احمد بن طولون كان موضعها من قطائع بن طولون ، فقام الأمير $(1 \cdot r)$

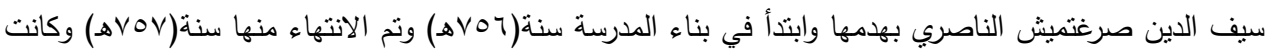

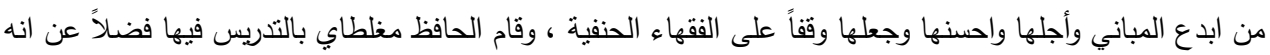
درس الحديث الثريف أول ما افتتحت

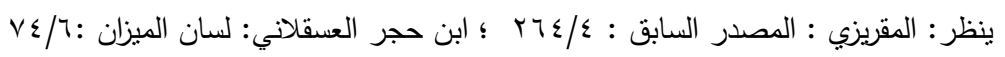

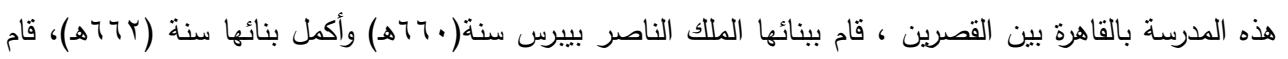
$(1 \cdot r)$

$$
\begin{aligned}
& \text { مغلطاي بمشيخة الحديث بالمدرسة الظاهرية . }
\end{aligned}
$$

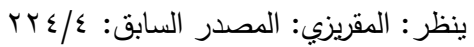

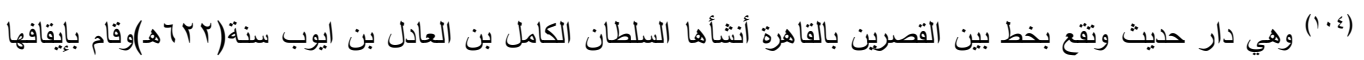

$$
\text { المشتغلين بالحديث النبوي. }
$$

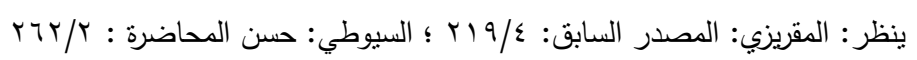

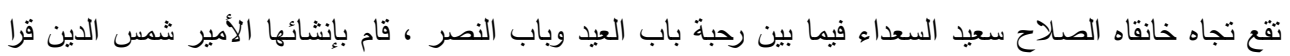
$(1.0)$ سنقر المنصوري سنة( · Vهـ) وجعل فيها درساً للفقهاء.

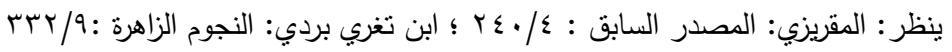

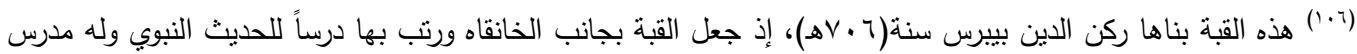

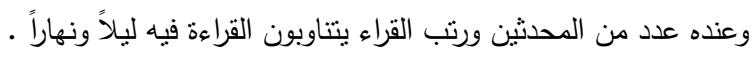

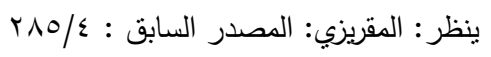

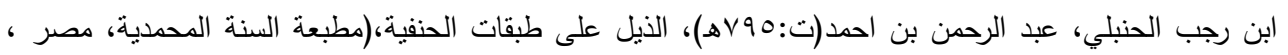

$$
\begin{aligned}
& \text { أعيان العصر : }
\end{aligned}
$$

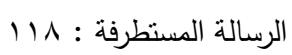

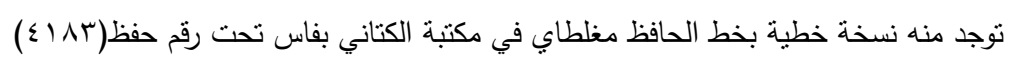

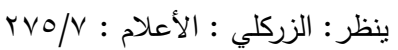

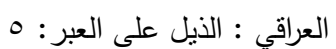




\section{العـــــــد الثاني والعشرون}

\section{مجلـــة كليــــة التربيـــة}

بنظر : ابن فهز الدكي: لحظ الألحاظ :

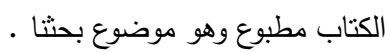
(i)i

"وهو تعقيب على كتاب مقدمة علوم الحديث لابن الصلاح ، والكتاب مخطوط منه نسخة خطية في المكتبة الخديوية (1)

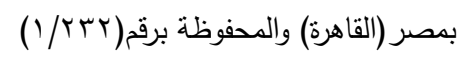

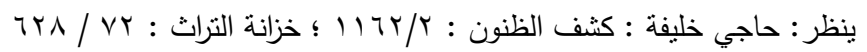

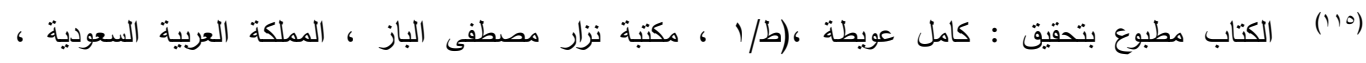

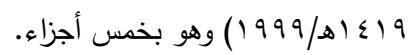

ان الحافظ مغلطاي من جملة من جمع دلاثل النبوة ، وهو لا يزال مخطوطاً (1'1)

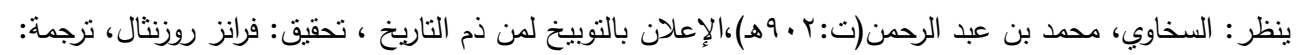

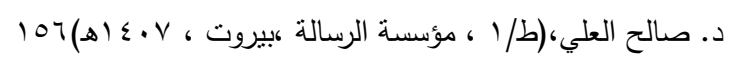

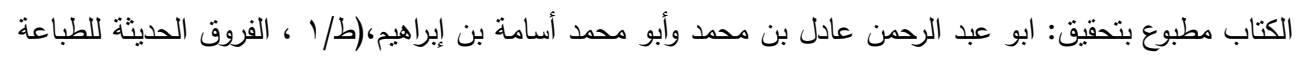
$(1) v)$

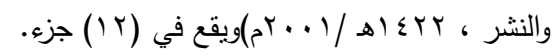

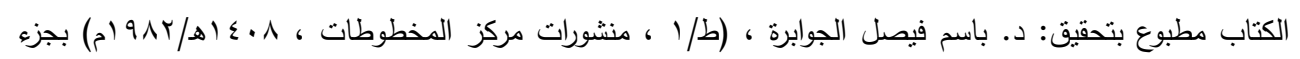
$(11 \lambda)$ واحد. تعقب فيه الحافظ المزي أيضاً في تحفة الأشراف بمعرفة الأطراف. ينظر : السيوطي: تاريخ الخلفاء: ع اه. يقع الكتاب في مجلدين اختصر به الكمال تهذيب الكمال مقتصراً على الاعتراضات التي أخذها على الحافظ المزي،

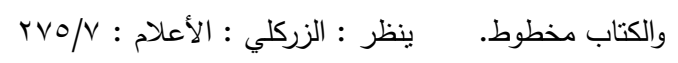

وهو كتاب في اللغة وقيل ان المجلد الأول منه تم بخط الحافظ مغلطاب ، منه نسخة محفوظة في خزانة الرباط برقم

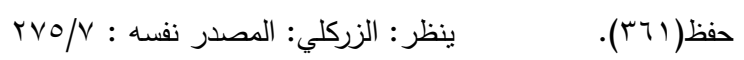

قام الحافظ مغلطاي بتأليفه رداً على القائلين من علماء عصره بان مرضعة النبي لئك حليمة السعدية لم تسلم ، والكتاب

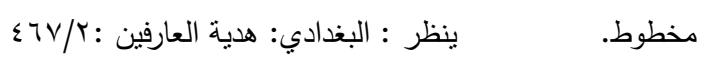

الكتاب مطبوع بتحقيق طلاب وطالبات مرحلة الماجستير ،(ط/ ، دار المحدث للنشر والتوزيع ، المملكة العربية

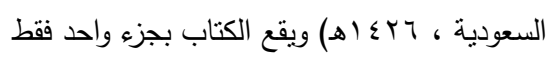

$$
\text { رتبه على أبواب الفقه وذكر ان ابن حجر العسقلاني رآه بخطه وانه لم يكمله. }
$$

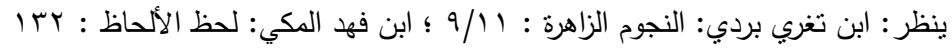

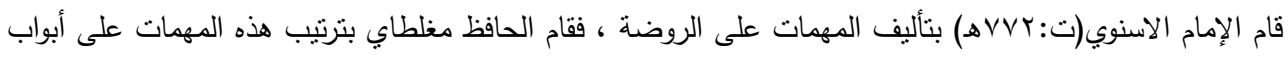

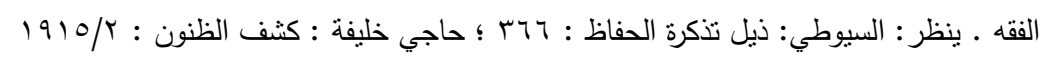

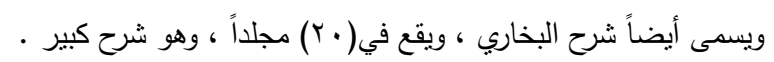

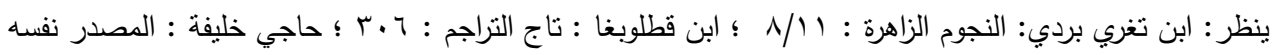

$$
0 \leq \uparrow / 1 \text { : }
$$

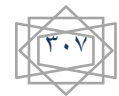


(irv) (الكتاب مخطوط منه نسخة خطية محفوظ في مكتبة المصغرات الفيلمية لقسم المخطوطات بالجامعة الإسلامية ، المملكة

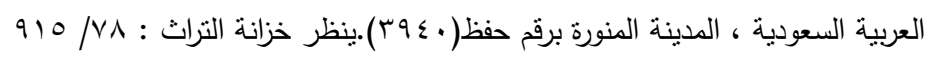

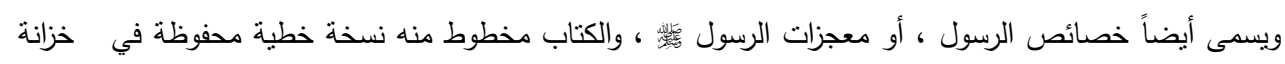

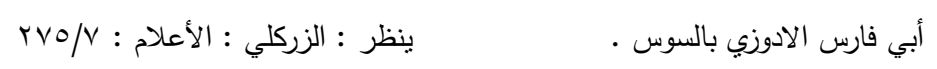

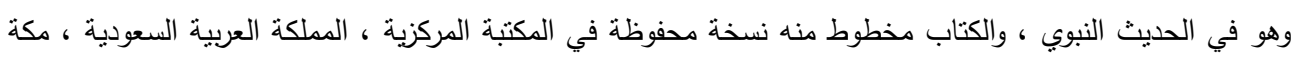

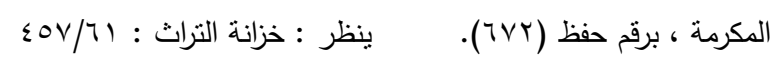

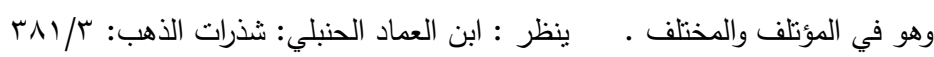

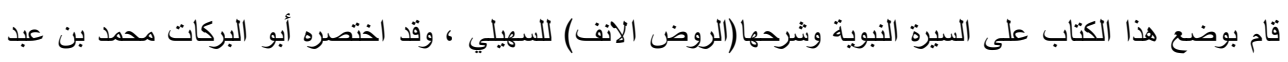
(Ir) الرحيم(ت:VVT)

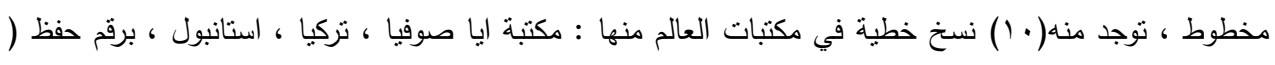

$$
\text { 9 آ آب). }
$$

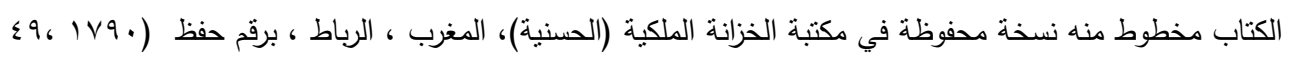
$(1+r)$

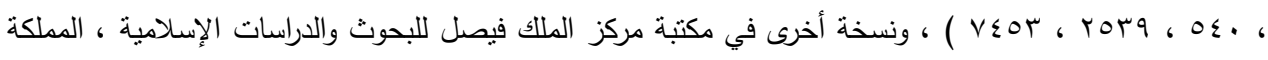

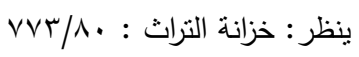

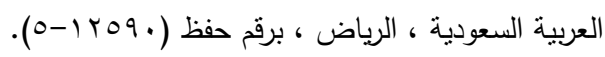

$$
\text { 1/117، }
$$

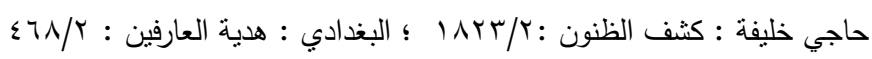
الكتاب مخطوط منه نسخة محفوظة في مكتبة مركز الملك فيصل للبحوث والدراسات الإسلامية ، المملكة العربية $(1 r \varepsilon)$

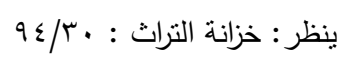

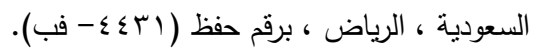

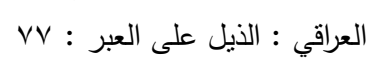

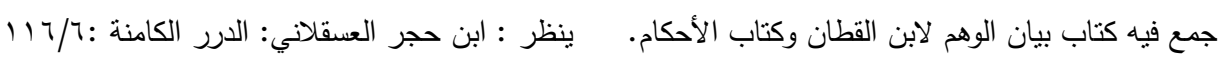
$(1+4)$

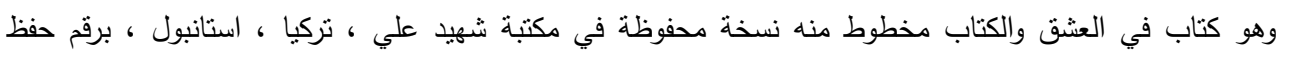
$($ (IrY)

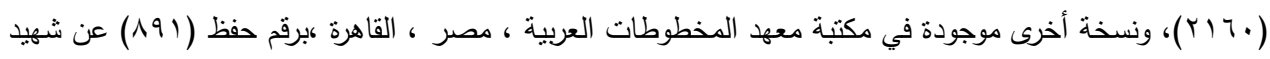

$$
\text { علي(.) (Y) }
$$

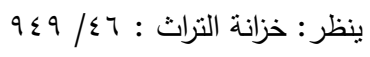

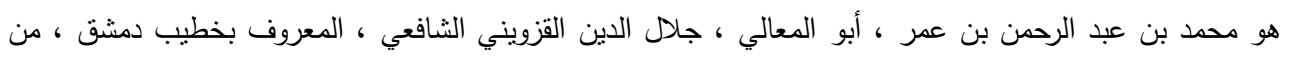
$(1+\lambda)$

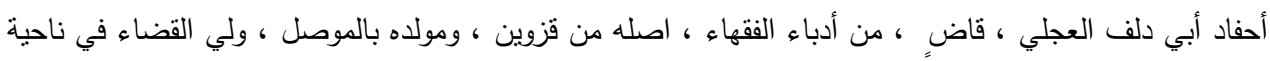

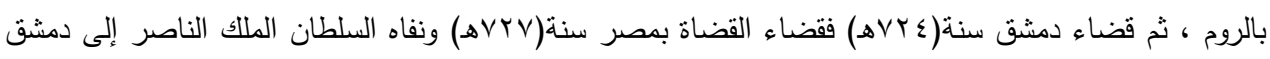

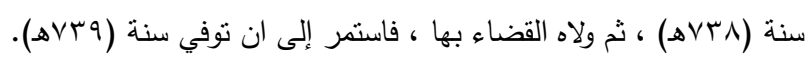

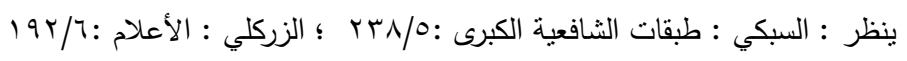

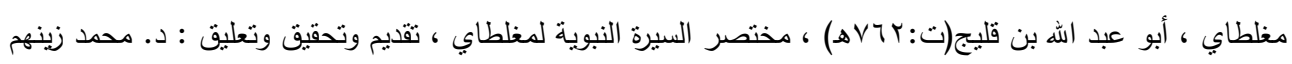
$(1+9)$

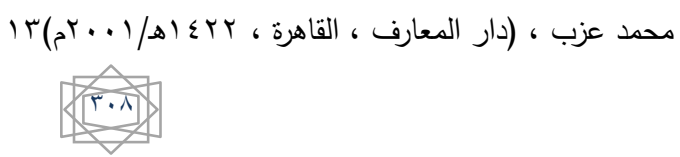




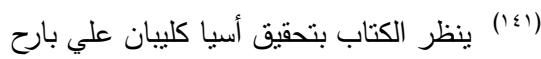

(rأ) وهذا الذيل نوجد منه نسخة خطية محفوظة في مكتبة المصغرات الفيلمية لقسم المخطوطات بالجامعة الإسلامية ،المملكة

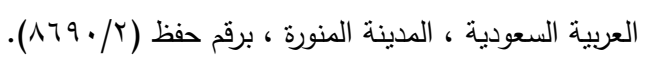

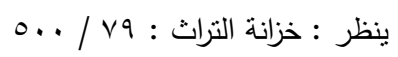

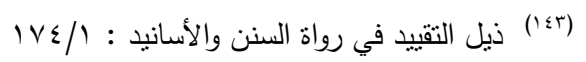

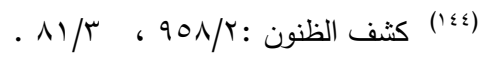

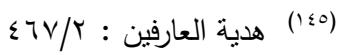

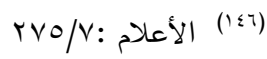

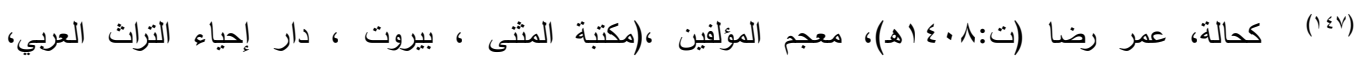

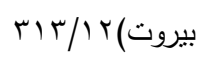

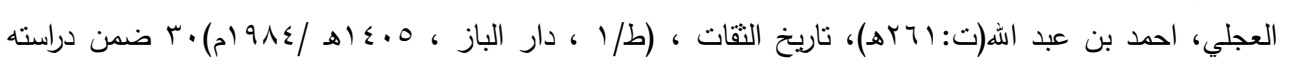
للكتاب.

فقيهي، عبد الحميد بن علي : جهود العلماء المسلمين في تصنيف السيرة النبوية في القرنين الثامن والتاسع الهجريين ،

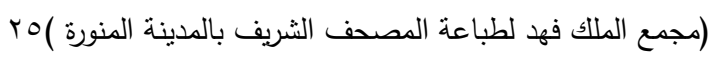

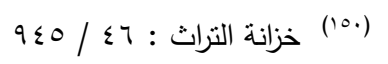

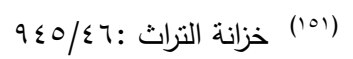
(10r) (lor) (10) المصدر نفسه (10) (100) المصدر نفسه (100) (107) (107)

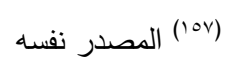

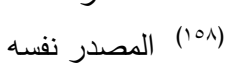
(109) المصدر نفسه (109)

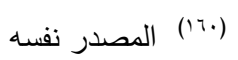

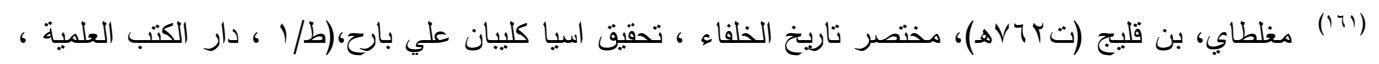

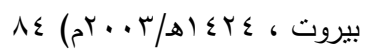

$$
\begin{aligned}
& \text { (זT) }
\end{aligned}
$$

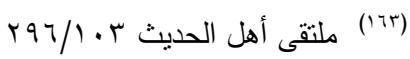

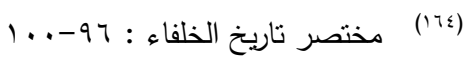




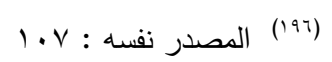

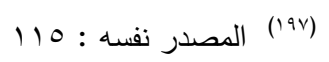

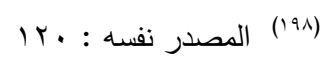

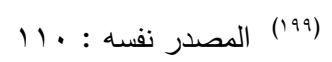

$$
\begin{aligned}
& \text { 1 المصدر نفسه : (Y...) } \\
& \text { (r. }
\end{aligned}
$$

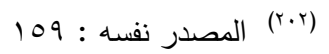

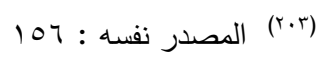

$$
\begin{aligned}
& \text { (r.\&) }
\end{aligned}
$$

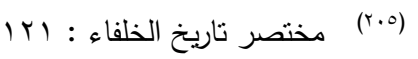

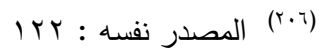

$$
\begin{aligned}
& \text { (r.V) } \\
& \text { IYV : (r.^) } \\
& \text { (r.9) }
\end{aligned}
$$

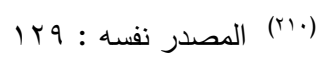

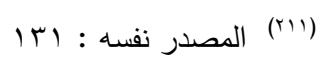

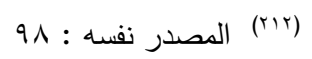

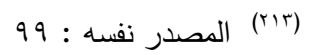

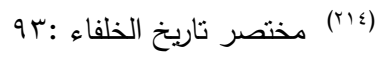

$$
\begin{aligned}
& 91 \text { : (r/O) }
\end{aligned}
$$

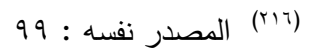

$$
\begin{aligned}
& 90 \text { : (r)v) }
\end{aligned}
$$

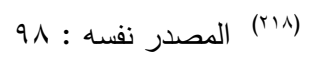

$$
\begin{aligned}
& 99 \text { : (r/9) }
\end{aligned}
$$

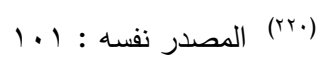

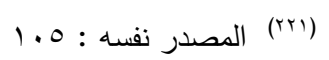

$$
\begin{aligned}
& \text { (TrY) المصدر نفسه : (Yr) }
\end{aligned}
$$

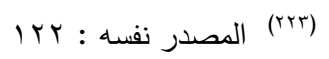

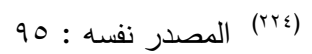

$$
\begin{aligned}
& 91 \text { : (rro) }
\end{aligned}
$$

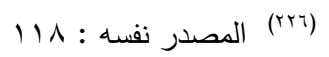




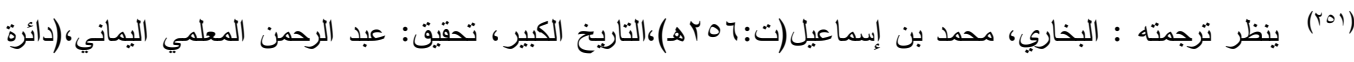

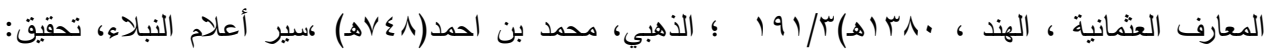

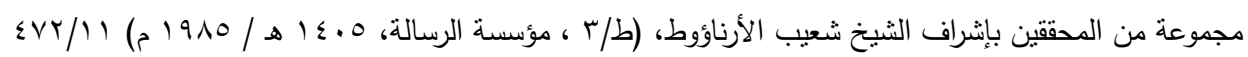

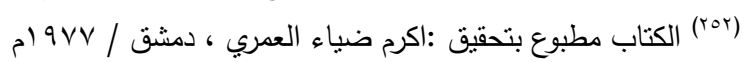

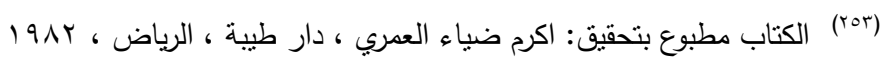

91 : مختصر تاريخ الخلفاء (ros) (roo) 


\section{العـــــــد الثاني والعشرون}

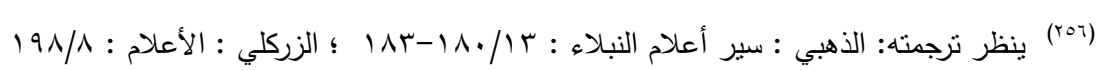

(rov)

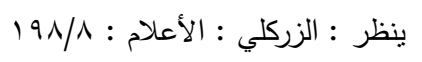

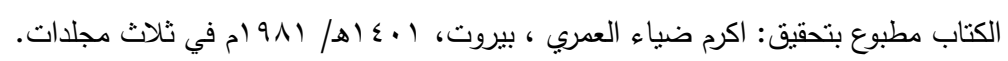

91 : مختصر ناريخ الخلفاء

المصدر نفسه .

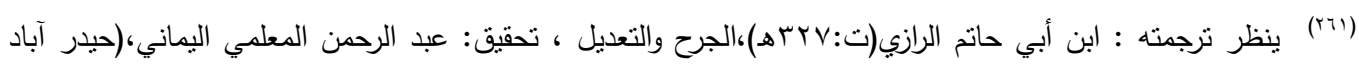

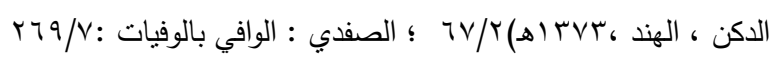

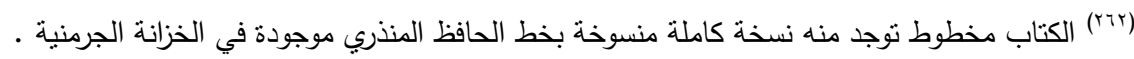

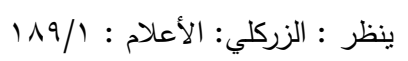

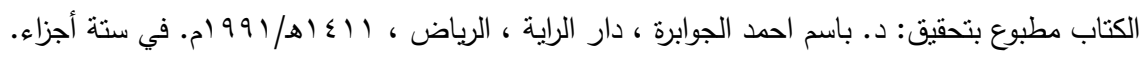

$$
\text { المصدر نفسر تاريخ الخلفاء: . . 1 }
$$

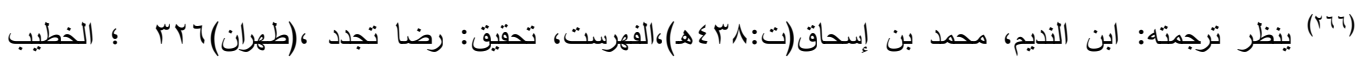

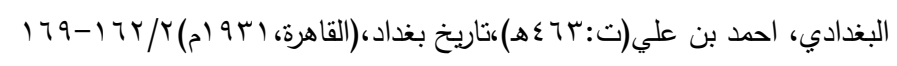

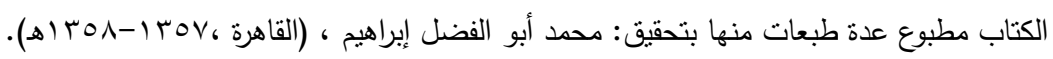

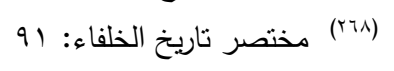

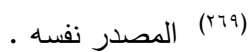

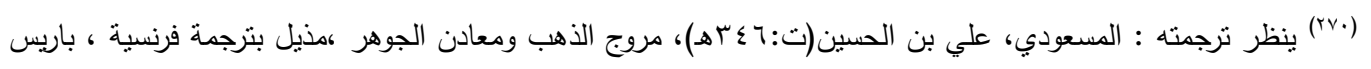

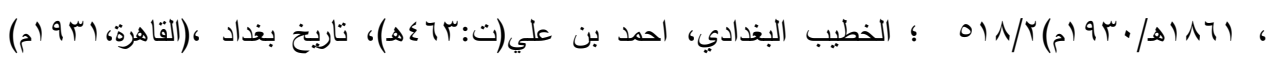

$$
\begin{aligned}
& 19 \gamma-190 / r
\end{aligned}
$$

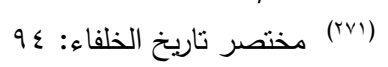

$$
\begin{aligned}
& \text { (YVT) }
\end{aligned}
$$

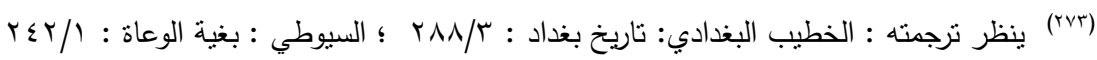

$$
91 \text { : مختصر تاريخ الخلفاء (rv\&) }
$$

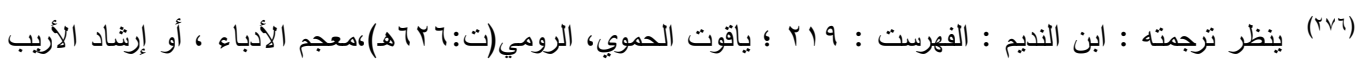

$$
\begin{array}{r}
\text { (YVY) } \\
\text { (YVY) }
\end{array}
$$




\section{العـــــــد الثاني والعشرون}

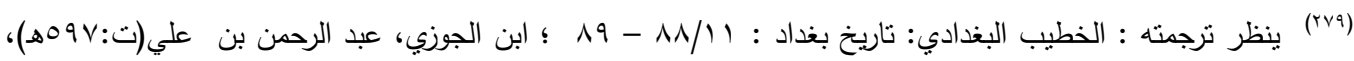

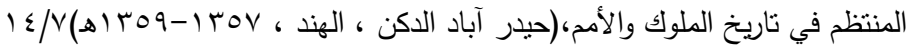

$$
\begin{aligned}
& 91 \text { : (r^.) } \\
& \text { (YN) }
\end{aligned}
$$

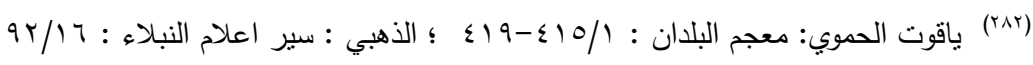

$$
\begin{aligned}
& \text { qr: مختصر تاريخ الخلفاء (rNr) } \\
& \text { (r^乏) }
\end{aligned}
$$

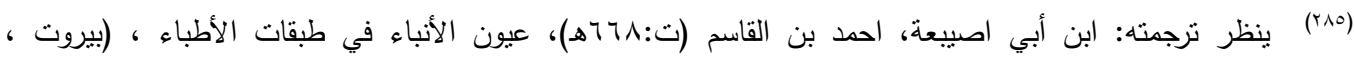

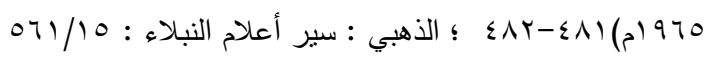

$$
9 r \text { : مختصر ناريخ الخلفاء (rN ) }
$$

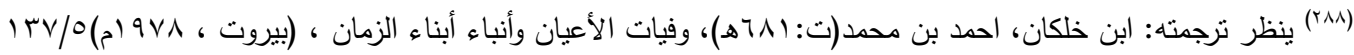

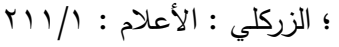

$$
\begin{aligned}
& 91 \text { : (rAq) }
\end{aligned}
$$

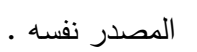

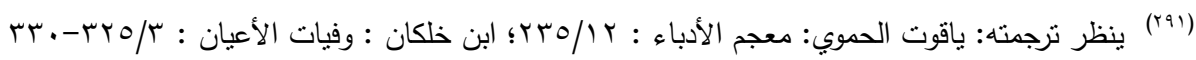

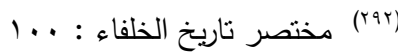

$$
\begin{aligned}
& \text { ( }
\end{aligned}
$$

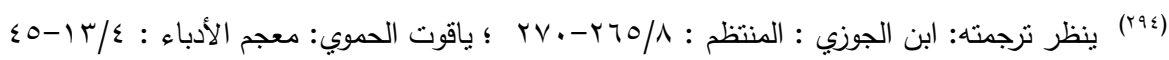

$$
91 \text { : (190) }
$$

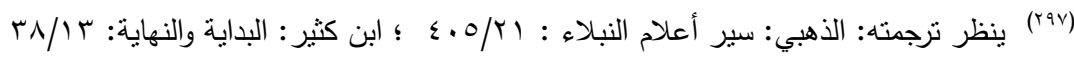

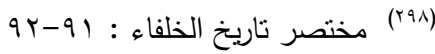

$$
\begin{aligned}
& \text { (raq) }
\end{aligned}
$$

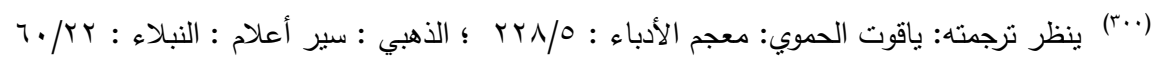

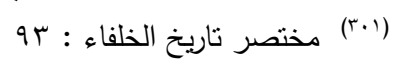

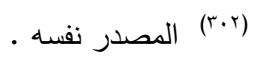

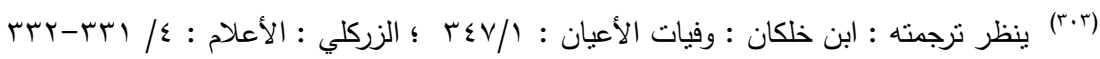

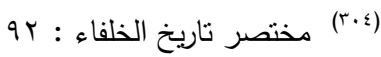

$$
\begin{aligned}
& \text { (r.0) }
\end{aligned}
$$

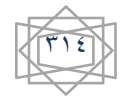




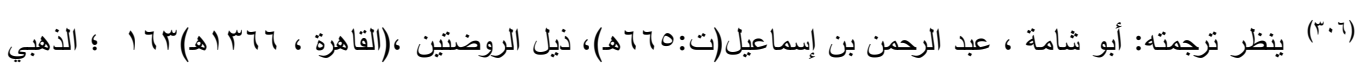

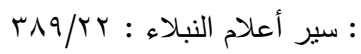

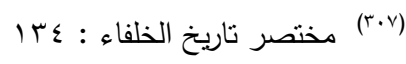

$$
\begin{aligned}
& \text { (r.^) }
\end{aligned}
$$

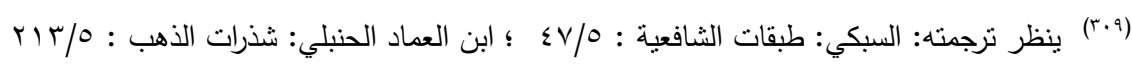

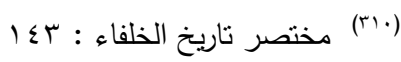

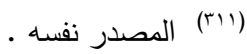

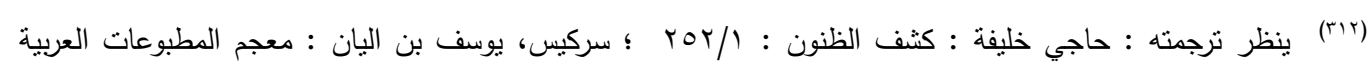

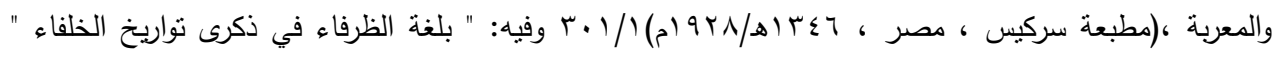

$$
\begin{aligned}
& \text { وصل به إلى المستعصم العباسي". } \\
& \text { Tr : } \\
& \text { ( ) }
\end{aligned}
$$

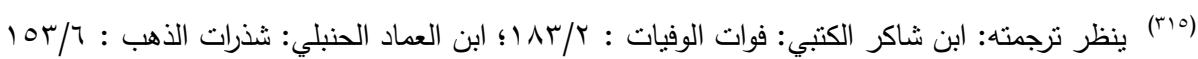

$$
\begin{aligned}
& 170 \text { (T) } 17 \text { (T) مختصر تاريخ الخلفاء } \\
& \text { (r)v (r) المصدر نفسه (r) }
\end{aligned}
$$

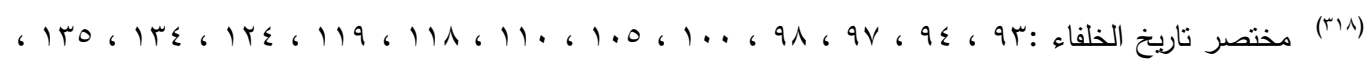

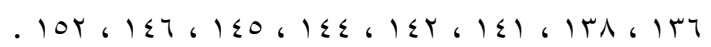

$$
\text { (r) (r/9) }
$$

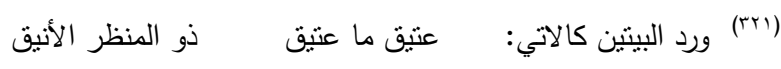

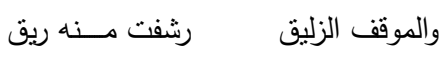

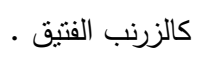

ينظر: مغلطاي، بن قليج (ت بوVه)، اكمال تهذيب الكمال في أسماء الرجال ، تحقيق: أبو عبد الرحمن عادل بن

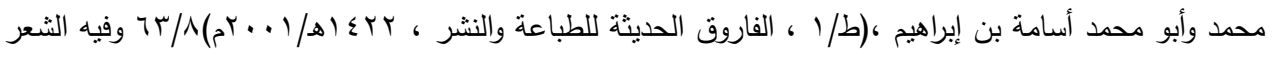

$$
\begin{aligned}
& \text { منسوب الى سلمى بنت صخر . }
\end{aligned}
$$

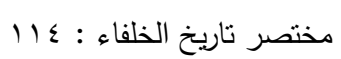

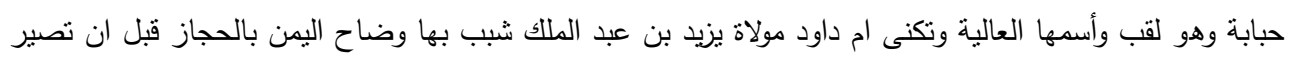
(rrT)

إلى يزيد ، أخذت الغناء عن ابن سريج ومعبد وغيرهما ، وكانت احسن أهل عصرها وجهاً وغناء وأحلاهم منظراً.

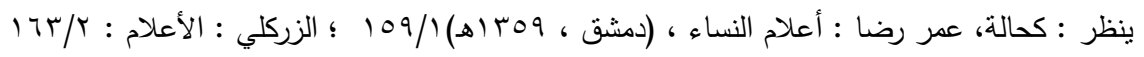

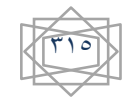




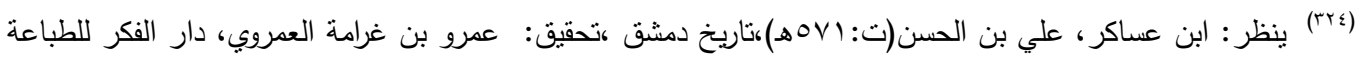

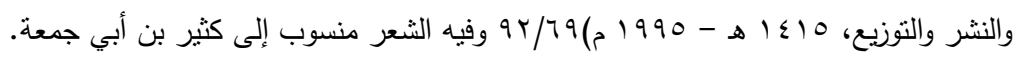

111 : مختصر (rro)

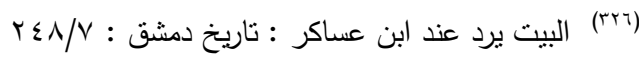

مختصر تاريخ الخلفاء : بrr)

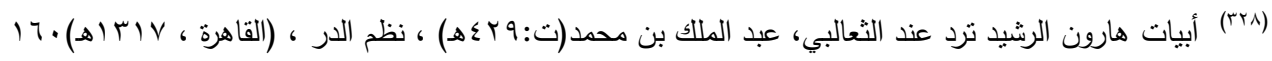

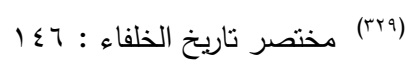

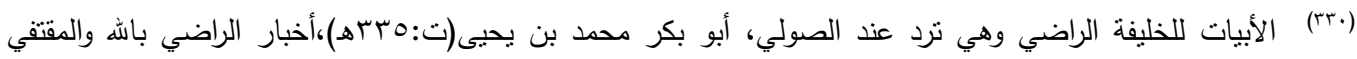

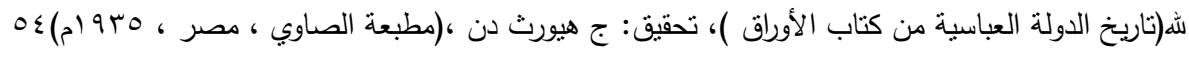

